\title{
Synthesis, structures and applications of electron-rich polyoxometalates
}

\author{
Nadiia I. Gumerova ${ }^{a, b}$ and Annette Rompel ${ }^{a}$ \\ a Universität Wien, Fakultät für Chemie, Institut für Biophysikalische Chemie, Althanstr. 14, 1090 Wien, Austria. www.bpc.univie.ac.at. \\ E-Mail: annette.rompel@univie.ac.at \\ b Vasyl' Stus Donetsk National University Department of Inorganic Chemistry, 21021 Vinnytsia, Ukraine.
}

Electron-rich polyoxometalates (POMs), known since the early discovery and development of POM chemistry, are POMs incorporating extra electrons upon reduction and comprise an emergent family of different archetypes, structural flexibility and functionality. Here, we describe synthetic strategies to obtain electron-rich POMs with important catalytic, electronic and magnetic properties and discuss their differences and advantages compared to their fully oxidized analogues. This is the first review summarizing the existing knowledge about polyoxometalate reduction, encompassing a comprehensive description of reduced compounds (over 200 structures are reviewed) and the influence the reduction causes on the structure, function and properties of this molecule class.

Polyoxometalates (POMs) are a large group of transformable discrete anionic polynuclear metal-oxo clusters. These compounds contain arrays of corner- and edge-sharing pseudo-octahedrally coordinated $\mathrm{MO}_{6}(\mathrm{M}=\mathrm{V}, \mathrm{Nb}, \mathrm{Mo}, \mathrm{W})$ units, packed to form an ionic core, where the electronic configuration of the metal is usually $\mathrm{d}^{0}$ or $\mathrm{d}^{1}$ (metals in their highest oxidation states). ${ }^{1}$ These metals are commonly called addenda atoms or peripheral elements and their ionic radii and charge are suitable for $\mathrm{O}^{2-}$ coordination. The coordination number of the addenda atoms can be increased from 4 to 6 upon acidification and they are able to form double bonds with unshared terminal oxygens in $\mathrm{MO}_{6}$ octahedra through $\mathrm{p}_{\pi}-\mathrm{d}_{\pi}$ interactions. One of the most widely accepted classification of POMs divides them into two groups: 1) isopolyanions (IPAs), which consist of only one type of metal (M) atom, $\left[\mathrm{M}_{\mathrm{m}} \mathrm{O}_{y}\right]^{\mathrm{q}^{-}}$, and 2) heteropolyanions (HPAs), with the general formula $\left[\mathrm{X}_{\mathrm{r}} \mathrm{M}_{\mathrm{m}} \mathrm{O}_{\mathrm{y}}\right]^{\mathrm{q}^{-}}$, where $\mathrm{X}$ is the so-called heteroatom. POMs have multiple applications in various areas, such as catalysis, ${ }^{2,3}$ bioand nanotechnology, ${ }^{4}$ medicine, ${ }^{5-6}$ macromolecular crystallography, ${ }^{7-9}$ electrochemistry, ${ }^{10}$ material sciences ${ }^{11}$ and molecular magnetism ${ }^{12}$ and many of them are related to their redox properties. POMs are often recognized as electron reservoirs because of their strong capacity to bear and release electrons indicating their redox nature. ${ }^{13}$ POMs can be regarded as soft Lewis bases due to the abundant oxygen atoms that can donate electrons to electron acceptors. However, the addenda metal ions of the polyanion skeletons possess unoccupied orbitals that can accept electrons and thereby act as Lewis acids. ${ }^{2}$

The reduced, also called electron-rich, POMs typically retain the general structure of their parent molecule and are often characteristically deep blue in color comprising a very large group of complexes known as the "poly blues" or "heteropoly blues" (FIG. 1). Their blue color is the result of intense $d-d$ electron transitions and intervalence chargetransfers. ${ }^{14}$ 


\section{a Isopolyanions}

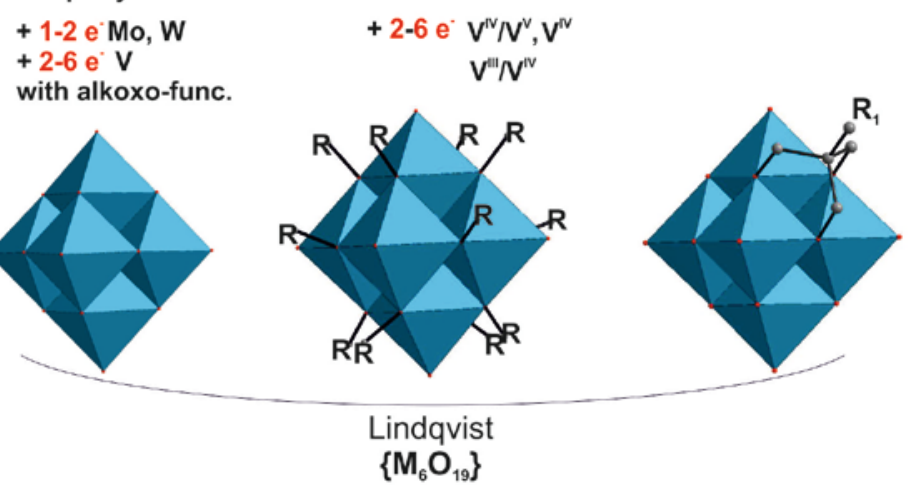

\section{b Keggin based}

$+1-12$ e Mo

$+1-6$ e W

up to 24 for metatungstate

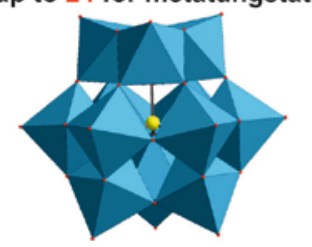

Keggin

$\left\{\mathrm{XM}_{12} \mathrm{O}_{40}\right\}$

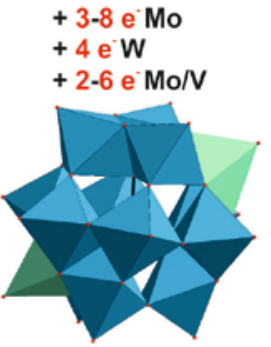

Bi-capped

$\left\{\mathrm{XM}_{12} \mathrm{O}_{40}(\mathrm{VO})_{2}\right\}$

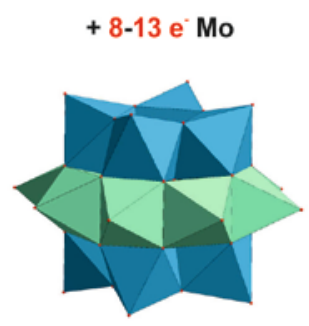

Tetra-capped $\left\{\mathrm{XM}_{8} \mathrm{~V}_{4} \mathrm{O}_{40}(\mathrm{VO})_{4}\right\}$

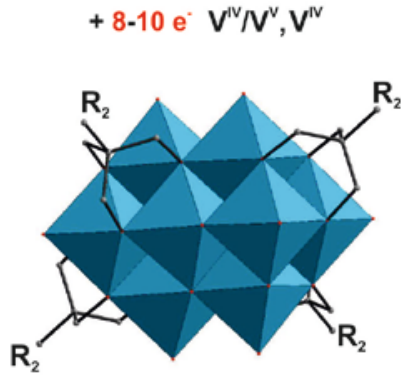

Decavanadate $\left\{\mathbf{V}_{10} \mathrm{O}_{26}\right\}$

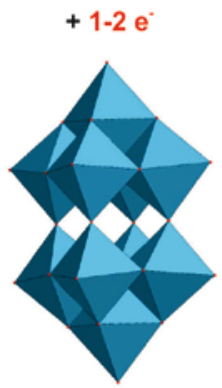

Decatungstate $\left\{\mathrm{W}_{10} \mathrm{O}_{32}\right\}$ c Dawson based

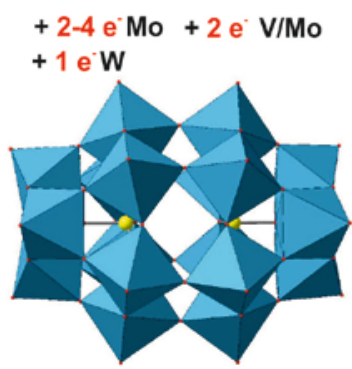

Wells-Dawson $\left\{\mathrm{X}_{2} \mathrm{M}_{18} \mathrm{O}_{62}\right\}$

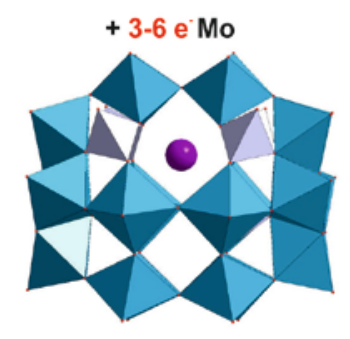

Basket-like $\left\{X \subset \mathrm{P}_{6} \mathrm{Mo}_{18} \mathrm{O}_{73}\right\}$

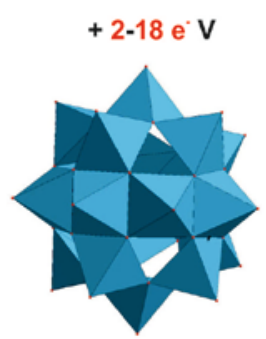

Spherical $\left\{\mathrm{V}_{18} \mathrm{O}_{42}\right\}$

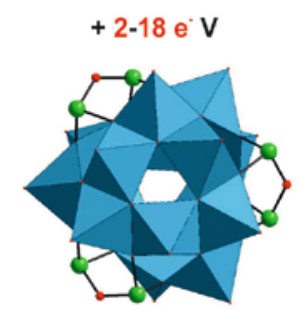

Spherical

$\left\{X_{6} V_{15}\right\}$

d Anderson-like

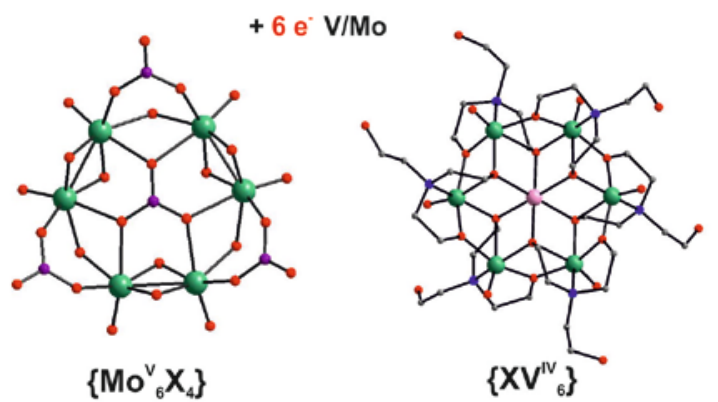

Figure 1 | Conventional types of electron-rich POMs. a | Isopolyanios: Linqvist type isopolymolybdate, -tungstate $\left\{\mathrm{M}_{6} \mathrm{O}_{19}\right\}$ $(M=M o, W)$ and organically functionalized vanadates $\left\{V_{6} O_{n}(O R)_{19-n}\right\}$ or $\left\{V_{6} \mathrm{O}_{19-3 n}\left(\left(O_{C H}\right)_{3} C R^{1}\right) n\right\}\left(R=-C_{3},-C_{2} H_{5} ; R^{1}=-C_{3}\right.$, $\left.\mathrm{C}_{2} \mathrm{H}_{5},-\mathrm{CH}_{2} \mathrm{OH},-\mathrm{NO}_{2}\right)$, decatungstate $\left\{\mathrm{W}_{10} \mathrm{O}_{32}\right\}$ and functionalized decavanadates $\left\{\mathrm{V}_{10} \mathrm{O}_{28-3 n}\left(\left(\mathrm{OCH}_{2}\right)_{3} \mathrm{CR}^{2}\right)_{n}\right\}\left(\mathrm{R}^{2}=-\mathrm{C}_{2} \mathrm{H}_{5},-\mathrm{CH}_{2} \mathrm{OH}\right)$. Color code: $\mathrm{MO}_{6}$, blue polyhedra. b | Keggin based anions: classical Keggin anion $\left\{\mathrm{XM}_{12} \mathrm{O}_{40}\right\}$ (X-heteroatom, which is missing in metatungstate, $\mathrm{M}=\mathrm{Mo}, \mathrm{W}$ ); bi- and tetra-capped pseudo-Keggin anions. Color code: $\mathrm{MO}_{6}$, blue polyhedra; $\mathrm{VO}_{5}$, green polyhedra. Examples of vanadium spherical anions $\left\{\mathrm{V}_{18} \mathrm{O}_{42}\right\}$ and $\left\{\mathrm{X}_{6} \mathrm{~V}_{15} \mathrm{O}_{42}\right\}\left(\mathrm{X}=\mathrm{As}, \mathrm{Sb}, \mathrm{Ge}\right.$, and Si). Color code: $\mathrm{VO}_{\mathrm{n}}$, blue polyhedra; $\mathrm{X}$, green spheres. $\left\{\mathrm{V}_{18} \mathrm{O}_{42}\right\}$ is an isopolyanion, hovewer based on the structural classification it is presented in the Keggin based anions section. $\mathbf{c}$ | Wells-Dawson based anions: classical $\left\{\mathrm{X}_{2} \mathrm{M}_{18} \mathrm{O}_{62}\right\}$ (X-heteroatom, $\left.\mathrm{M}=\mathrm{Mo}, \mathrm{W}, \mathrm{V}\right)$ and basketlike $\left\{\mathrm{X} \subset \mathrm{P}_{6} \mathrm{Mo}_{18}\right\}\left(\mathrm{X}\right.$ - alkali metal) archetypes. Color code: $\mathrm{MO}_{6}$, blue polyhedral; $\mathrm{X}$ - yellow or purple spheres. $\mathbf{d} \mid$ Andersonlike anions: left - $\left[\left(\mathrm{Mo}_{2}{ }_{2} \mathrm{O}_{4}\right)_{3}\left(\mathrm{CO}_{3}\right)_{4}(\mathrm{OH})_{3}\right]^{5-219}$; right - $\left.\mathrm{XV}_{6}^{\mathrm{IV}}{ }_{6} \mathrm{O}_{6}\left\{\left(\mathrm{OCH}_{2} \mathrm{CH}_{2}\right)_{2} \mathrm{~N}\left(\mathrm{CH}_{2} \mathrm{CH}_{2} \mathrm{OH}\right)\right\}_{6}\right]^{\mathrm{n+}}(\mathrm{X}=\mathrm{Li}, \mathrm{Na}, \mathrm{Mg}, \mathrm{Mn}, \mathrm{Fe}, \mathrm{Co}, \mathrm{Ni})^{206}$. Color code: V/Mo, green; M, pink; N, blue; C, violet; O, red. 
The most prominent reduced POMs are the mixed-valence molybdenum blue $\mathrm{Mo} / \mathrm{Mo}^{\mathrm{VI}}$ "giant wheels" based on $\left\{\mathrm{Mo}_{154}\right\}$ units, which are obtained by partial reduction of $\mathrm{Na}_{2} \mathrm{MoO}_{4}$ with a reducing agent (e.g. $\mathrm{N}_{2} \mathrm{H}_{4}, \mathrm{NH}_{2} \mathrm{OH}, \mathrm{SnCl}_{2}$ ) in acidic solutions. ${ }^{15,16}$ "Heteropoly "browns" are polyoxotungstates (POTs) generated by spontaneous intraionic disproportionation of the $W^{V}$ atoms in the "blue" species under acidic conditions yielding more higly reduced $\mathrm{W}^{\mathrm{IV}} \mathrm{O}_{6}$ octahedra. ${ }^{17,18}$

The added electrons can be either localized on a metal ion or delocalized as "extra" electrons over a number of metal ions leading to an increased electron density on the terminal oxygen ions of the POM. The delocalized electrons can be considered either as thermally activated electrons hopping from one addendum ion to the next or as electron ground-state delocalization. The latter presumably involves $\pi$ bonding through bridging oxygens from the reduced metal ion $M^{v}$ to its oxidized neighbor addendum $\mathrm{M}^{\mathrm{V} / 14}$

The capacity to reduce a particular POM depends on the charge to nuclearity ratio and for heteropolyanions the kind and oxidation state of the heteroatoms must be taken into consideration. In 1972, Pope ${ }^{19}$ divided all POMs into three types: type I, which comprises polyanions in which each addendum atom has one unshared terminal oxo ligand, type II, characterized by two unshared terminal oxo ligands per addendum atom, and type III, as a combination of the two former. Pope predicted that only type I and III polyanions can be reversibly reduced. According to the molecular orbital theory of oxotype octahedral complexes, species with one unshared oxygen (type I) have one non-bonding $t_{2 g}$ orbital, which can accommodate one or two electrons by reduction, however, anions with two unshared oxygens (type II) lack the non-bonding $t_{2 g}$ orbital, because in the orbitals participate in the $\pi$-bonding. ${ }^{20}$ Consistent with this early paradigm, up to date there is no data about reduction of Anderson-type anions $\left(\left[\mathrm{XMo}_{6} \mathrm{O}_{24} \mathrm{H}_{\mathrm{x}}\right]^{\mathrm{n}-}, \mathrm{X}=\right.$ heteroatom; $\left.\mathrm{M}=\mathrm{Mo}, \mathrm{W} ; \mathrm{x}=0-6\right)$ or octamolybdates $\left(\left[\mathrm{Mo}_{8} \mathrm{O}_{26}\right]^{4-}\right)$, which belong to type II POMs. However, it is possible to reduce the heptamolybdate anion $\left[\mathrm{Mo}^{\mathrm{V}}{ }_{7} \mathrm{O}_{24}\right]^{6-}$ (type II by Pope classification) photochemically through the formation of an intermediate complex bearing only one unshared oxygen atom as in type . $^{21-22}$

Polyoxomolybdates (POMos) are more readily reduced than their isostructural POTs, and therefore Mo ions are preferentially reduced in mixed-metal Mo/W POMs. ${ }^{23}$ The isostructural POMos have potentials that are about $400 \mathrm{mV}$ more positive than the corresponding POTs, for example, the one-electron reduction potential in acetone for $\alpha-\mathrm{PW}_{12}$ is $-895 \mathrm{mV}$, whereas for $\alpha-\mathrm{PMo}_{12}$ it is $-468 \mathrm{mV} .^{24}$ In POMs exhibiting the common Keggin structure $\left[\mathrm{XM}_{12} \mathrm{O}_{40}\right]^{\mathrm{n}-}(\mathrm{X}=$ heteroatom, $\mathrm{M}=\mathrm{Mo}$, $\mathrm{W}, \mathrm{Nb}$ ), which consists of 12 addenda atoms, the number of accepted electrons can vary from $1^{25}$ to $12^{26}$ for POMos, but for the analogous POTs the maximum number of "blue" electrons is $6^{18}$ (TABLE 1). Vanadium addenda ions accept electrons even better than molybdenum ions (one-electron reduction potential for $\alpha-P V W_{11}$ is $600 \mathrm{mV}^{10}$ ). It has been demonstrated that in a spherical $\left\{\mathrm{V}_{18} \mathrm{O}_{42}\right\}$ structureall vanadium ions are reduced to $\mathrm{V}^{\mathrm{IV}}$ leading to an accepted number of 18 electrons.

POMs can be reduced in different ways, for example, photochemically, ${ }^{21,27,28}$ electrolytically $^{1}$ and in the presence of reducing reagents (metals, $\mathrm{B}_{2} \mathrm{H}_{6}, \mathrm{NaBH}_{4}, \mathrm{~N}_{2} \mathrm{H}_{4}, \mathrm{NH}_{2} \mathrm{OH}, \mathrm{H}_{2} \mathrm{~S}, \mathrm{SO}_{2}, \mathrm{SO}_{3}{ }^{2-}, \mathrm{S}_{2} \mathrm{O}_{4}{ }^{2-}, \mathrm{S}_{2} \mathrm{O}_{3}{ }^{2-}, \mathrm{SnCl}_{2}, \mathrm{MoCl}_{5}, \mathrm{MoOCl}_{5}{ }^{2-}$, Mohr's salt, formic acid, ethanol, ascorbic acid, tartaric acid, thiourea, hydroquinone, D-glucose, sucrose, etc.). Under hydrothermal conditions, $\mathrm{Mo}^{\mathrm{VI}}$ and $\mathrm{W}^{\mathrm{VI}}$ can accept one or two electrons ${ }^{1}$ and thusthe vast majority of reduced POMs are synthesized by the hydrothermal method. Reduced POMos are often air-stable, whereas reduced POTs are typically air-sensitive. ${ }^{14}$ Various oxidants, which contain $\mathrm{O}_{2}$ or $\mathrm{H}_{2} \mathrm{O}_{2}$, restore reduced POMs to the non-reduced ones. Since the reduction increases the nucleophilicity of the POMs, transition metal ions act as electrophiles and stabilize the POMs through covalent attachments. ${ }^{26}$ 
The characterization of reduced POMs can be challenging, especially in the case of mixed-metal compounds, where the usage of multiple complementary physical techniques is sometimes necessary just to determine the compound's formulation. A detection of the number and structural positions of the different metal centers can be achieved by single-crystal X-ray diffraction complemented by elemental analysis.

Table 1. Number of reduced electrons in POMs based on the Keggin structure $\mathbf{X M}_{12}(X=$ heteroatom; $M=M o, W)$..

\begin{tabular}{|c|c|c|}
\hline \multirow{2}{*}{$\begin{array}{c}\text { Type of addenda } \\
\text { ions }\end{array}$} & \multicolumn{2}{|c|}{ No. of accepted electrons } \\
\hline & $\min$ & $\max$ \\
\hline \multicolumn{3}{|c|}{ Keggin type $\mathrm{XM}_{12}$ (12 addenda ions) } \\
\hline$M=M o$ & $1^{25}$ & $12^{27}$ \\
\hline$M=W$ & $1^{120}$ & $6^{18}$ \\
\hline$M=M o, W$ & $2^{269}$ & $8^{109}$ \\
\hline \multicolumn{3}{|c|}{ Bi-capped Keggin type $\mathbf{X M}_{12} \mathbf{V}_{\mathbf{2}}$ (14 addenda ions } \\
\hline$M=M o$ & $3^{129}$ & $8^{130}$ \\
\hline$M=V, M o$ & $2^{139}$ & $6^{140}$ \\
\hline$M=W$ & $4^{149}$ & $4^{149}$ \\
\hline \multicolumn{3}{|c|}{ Tetra-capped Keggin type $\mathrm{XM}_{8} \mathrm{~V}_{\mathbf{8}}$ (16 addenda ions) } \\
\hline$M=M o$ & $8^{157}$ & $13^{158}$ \\
\hline
\end{tabular}

To obtain the number of electrons and their location and degree of delocalization in the POMs is a more challenging approach. Electron paramagnetic resonance (EPR) and X-ray photoelectron spectroscopy (XPS) can give insights into the valence of the metal centers, while magnetic measurements can indicate the number of unpaired electrons. In solution, redox titrations, electrochemistry, and $U \forall$ visible spectroelectrochemist ry are most useful for determining the exact degree of reduction. Paramagnetic electron-rich POMs are predominantly studied by EPR spectroscopy, while diamagnetic ones are investigated by NMR spectroscopy in solution. ${ }^{29}$ Computational chemistry has also become increasingly accurate and affordable for elucidating the electronic structure of reduced POMs. ${ }^{30}$ The theoretical analyses based on the AndersonHabbard ideas using quantum-chemical density functional theory (DFT) and $a b$ initio calculations or the parametric solution of exchange and delocalization problem provide a basis for further investigation of the multinuclear mixed-valence clusters.

As in the case of oxidized POMs reduced anions have been found the widest application as catalysts, due to their resistance to oxidative decomposition, high thermal stability, and sensitivity to light and electricity. ${ }^{27,}{ }^{32-35}$ Almost all types of reduced POMs with different degree of reduction demonstrate electrocatalytic activity and have been applied as reductive and oxidative electrocatalysts. The outstading photocatalytic activity of one-electron reduced decutungstate $\left[\mathrm{H}^{+} \mathrm{W}_{10} \mathrm{O}_{32}\right]^{5-}$ also should be noted. ${ }^{27}$ The magnetic susceptibility of a great number of electron-rich POMs was tested, but only some $V^{\mathrm{IV}}$ containing Keggin-based anions were applied as qubits for molecular spintronics ${ }^{35}$ or as molecular magnet ${ }^{36}$. Unlike most nanoparticle-protecting ligands, electron-rich POMs can reduce metal cations to colloidal metal(0) particles, which are then stabilized by the oxidized POM anions, and thus the POMs play a dual role, acting as both reducing agents and stabilizing 
anions. So far Keggin and Wells-Dawson electron-rich POMs with number of "blue" electrons from 1 to 8 were used as protecting ligands for metal(0) nanoparticles. ${ }^{37}$ Yamase group over the years tested isopolymolybdates (IPOMos) which can be reduced within cancer cells as anti-cancer agents, ${ }^{38,39}$ the Lindqvist type POV inhibits $\mathrm{Na}^{+} / \mathrm{K}^{+}$-ATPase, ${ }^{40}$ hovewer application of reduced POMs in biology is not elaborated enough and their role in this processes is not at all undersood. The unique stability of the Keggin structure allowing it to take up to 24 electrons makes it possible to use POMs based on this anion as electron storage device. ${ }^{41}$

Despite the long history of "heteropoly blues" the present review is the first one that summarizes and gives an overview of existing electron-rich POMs. The description of the reduced POMs is divided in two parts. The first section will discuss isopolyanions, where one or more Mo, $\mathrm{W}$ or $\mathrm{V}$ atoms are in a lower oxidation state, whereas the second part will describe reduced heteropolyanions based on their structural archetype, namely mixed-valence POMs based on Keggin structure (anions with classical and capped Keggin structure), mixed-valence POMs with Wells-Dawson structure and their derivatives (basket-like POMos and borophosphate POMos), Anderson-like fully reduced POVs and POMos and vanadium cluster compounds based on the spherical $\left\{\mathrm{V}_{18} \mathrm{O}_{42}\right\}$ archetype.. The reduced giant POMs developed by Müller et al. ${ }^{42}$ will be left out due to existing reviews ${ }^{43-44}$ about these compounds. Furthermore, the use of POMs as electron-accepting moieties in charge-transfer compounds developed by $\mathrm{Hill}^{45}$ and $\mathrm{Kochi}^{46}$, which are synthesized by co-crystallization with organic donors such as substituted amides, aromatic amines, or tetrathiafulvenes and decamethylferrocene, are not discussed in this review.

\section{Reduced isopolyanions}

\section{Isopolymolybdates}

The existing data about reduced isopolymolybdates (IPMos) are centered around the classical Lindqvist $\left[\mathrm{Mo}_{6} \mathrm{O}_{19}\right]^{2-}$ $\operatorname{archetype}^{47-50}$ (FIG. 1 a) and heptamolybdate $\left[\mathrm{Mo}_{7} \mathrm{O}_{24}\right]^{6-21,22}$ (FIG. 3 a), along with one-time synthesis of IPMos with structures that do not belong to one of the classical POM archetypes. ${ }^{-51-54}$ The photoreduction of alkylammonium polyoxomolybdates, ${ }^{21}$ namely hexa-, hepta and octomolybdates, is described by an example of heptamolybdate as the most extensive study. Up to now seven reduced IPMos, which accepted between one and twelve electrons, were crystallized and investigated by singlecrystal XRD (TABLE S1).

One-electron reduction of the Lindquist anion $\left[\mathrm{Mo}_{6}^{\mathrm{VI}}{ }_{6} \mathrm{O}_{19}\right]^{2-}$. According to the Cambridge Crystallographic Data Centre (CCDC) and Inorganic Crystal Structure Database (ICSD), up to date there are no data about crystal structures of reduced isopolymolybdates with Lindqvist structure (FIG. 1 a). Hovewer, in 1979, Che and co-workers described the controlled potential electrolysis of $\left[\mathrm{Mo}_{6} \mathrm{O}_{19}\right]^{2-}$ in dimethylformamide, which yielded the brown $\left[\mathrm{Mo}^{\mathrm{V}} \mathrm{Mo}_{5}{ }_{5} \mathrm{O}_{19}\right]^{3-}$ ion. ${ }^{48-50}$ They showed that the reduction step $\left[\mathrm{Mo}_{6}{ }_{6} \mathrm{O}_{19}\right]^{2-}+\mathrm{e}^{-} \leftrightarrows\left[\mathrm{Mo}^{\mathrm{V}} \mathrm{Mo}^{\mathrm{VV}}{ }_{5} \mathrm{O}_{19}\right]^{3-}$ is reversible and assumed that the structure of the parent oxidized form is retained upon reduction. EPR measurements of $\left[\mathrm{Mo}^{\mathrm{V}} \mathrm{Mo}_{5}{ }_{5} \mathrm{O}_{19}\right]^{3-}$ indicate thermal delocalisation of the valence electron with increasing temperature. ${ }^{48,49}$ The introduction of an electron which is localised on one molybdenum atom has a perturbing effect on the $\mathrm{Mo}^{\mathrm{V}}=\mathrm{O}_{\mathrm{t}}$ bond. ${ }^{47}$

Mechanism of heptomalybdate $\left[\mathrm{Mo}^{\mathrm{VI}}{ }_{7} \mathrm{O}_{24}\right]^{6-}$ reduction. According to Pope's hypothesis ${ }^{19}$ the heptamolybdate anion $\left[\mathrm{MoV}_{7} \mathrm{O}_{24}\right]^{6-}$ cannot be reduced due to the presence of two cis-dioxo groups within the $\mathrm{MoO}_{6}$ octahedron (type II POM by Pope classification). Thus, the reduction of $\left[\mathrm{Mo}^{\mathrm{VI}}{ }_{7} \mathrm{O}_{24}\right]^{6-}$ has so far only be observed by irradiation with ultraviolet light 
$142(\lambda \geq 313 \mathrm{~nm})$ in aqueous solution ${ }^{22}$ or in the solid state ${ }^{21}$ in the presence of the $\left[\mathrm{NH}_{3}{ }^{i} \mathrm{Pr}\right]^{+}\left({ }^{i} \mathrm{Pr}\right.$ - isopropyl) cation since the 143 proposed reduction mechanism involves an interaction between the heptamolybdate anion and the cation (FIG. 2 a). The 144 reduction of $\mathrm{Mo}^{\mathrm{VI}}$ takes place through the formation of an intermediate complex with one unshared oxygen, which is 145 characteristic for type I POMs according to Pope (FIG. 2 a, reaction I). This intermediate enables the reduction reaction and 146 therefore does not contradict Pope's theory. The EPR spectra revealed a localized octahedral $\mathrm{Mo}^{\mathrm{V}} \mathrm{O}_{5}(\mathrm{OH})$ site resulting from 147 an electron transfer between the anion and the counterion via hydrogen bonding. ${ }^{21,22}$ The X-ray structure of UV-irradiated 148 single crystal of $\left[\mathrm{NH}_{3}{ }^{i} \mathrm{Pr}\right]_{6}\left[\mathrm{Mo}_{6}{ }_{6} \mathrm{O}_{24}\right]$ is in agreement with the EPR by revealing the protonation of the bridged oxygen in the $149 \mathrm{Mo}^{\mathrm{V}} \mathrm{O}_{5}(\mathrm{OH})$ octahedra (FIG. 3 a). ${ }^{21}$

150 Electron acceptance as a key factor for the formation of new polymolybdate archetypes. The reduction of type II IPOMos 151 (octa- and hepta-anions) in non-aqueous solvents leads to the formation of novel mixed-valent POMos with structures 152 different from the parent anions. $\alpha$-Octamolybdate $\left(\mathrm{Bu}_{4} \mathrm{~N}\right)_{4}-\left[\mathrm{Mo}^{\mathrm{VI}}{ }_{8} \mathrm{O}_{26}\right]$, a typical type II POM, was reduced to the crosslike 153 octamolybdate anion $\left[\mathrm{Mo}_{4}{ }_{4} \mathrm{Mo}^{\mathrm{VI}}{ }_{4} \mathrm{O}_{24}\right]^{4-}$ by refluxing it with triethylenetetramine (TETA) and $\mathrm{N} \mathrm{N}^{\prime}$-dicyclohexylcarbodiimide 154 (DCC) in dry acetonitrile. The $\left[\mathrm{Mo}_{4}^{\mathrm{V}} \mathrm{Mo}^{\mathrm{VN}}{ }_{4} \mathrm{O}_{24}\right]^{4-}$ anion has an unusual $\mathrm{Mo}_{4}^{\mathrm{V}} \mathrm{O}_{8}$ cubane-like core and was termed $\chi-$ 155 octamolybdate due to its shape (FIG. 2 b). ${ }^{52}$

Cronin et al. ${ }^{54}$ obtained the novel mixed-valent "shrink-wrapped" anion $\left[\mathrm{H}_{2} \mathrm{Mo}_{4}{ }_{4} \mathrm{Mo}^{\mathrm{V}}{ }_{12} \mathrm{O}_{52}\right]{ }^{10-}$ by the addition of 157 protonated hexamethylenetetramine $\left(\mathrm{HMTAH}^{+}\right.$or $\left.\mathrm{C}_{6} \mathrm{H}_{13} \mathrm{~N}_{4}{ }^{+}\right)$as cation to the reaction solution that is typically used to for giant Mo cluster systems $\left(\mathrm{MoO}_{4}{ }^{2-}\right.$ and hydrazine). The large organic cation prevents the rapid aggregation of metal-oxide-based polyhedra to clusters with a stable uniform spherical topology. This novel compound contains an unusual platform-like $\mathrm{Mo}_{12}$ core (FIG. 2 c). ${ }^{54}$ The four $\mathrm{Mo}^{\mathrm{V}}$ centers comprise two centrosymmetrically related $\mathrm{Mo}_{2}{ }_{2}$ groups (located in the central part of the $\left[\mathrm{H}_{2} \mathrm{Mo}_{4}^{\mathrm{V}} \mathrm{Mo}^{\mathrm{VI}}{ }_{12} \mathrm{O}_{52}\right]^{10-}$ cluster core) displaying a short $\mathrm{Mo}(2)-\mathrm{Mo}(3)$ contact of $2.6427(4) \AA$, which is characteristic for 162 Mo - Mo single bonds.

163 The reaction of the Lindqvist nitrosyl derivative $\left({ }^{n} \mathrm{Bu}_{4} \mathrm{~N}\right)_{3}\left[\mathrm{Mo}_{5}{ }_{5} \mathrm{O}_{13}(\mathrm{OMe})_{4}(\mathrm{NO})\{\mathrm{Na}-(\mathrm{MeOH})\}\right]$ with $\mathrm{VCl}{ }_{3}$ in methanol 164 yields the two electron reduced nitrosyl decamolybdate $\left[\mathrm{Mo}_{2}{ }_{2} \mathrm{Mo}{ }_{7} \mathrm{O}_{25}(\mathrm{OMe})_{6}\left(\mathrm{Mo}{ }^{\prime \prime} \mathrm{NO}\right)\right]^{-}$and the reaction of $165\left({ }^{n} \mathrm{Bu}_{4} \mathrm{~N}\right)_{2}\left[\mathrm{Mo}_{5}{ }_{5} \mathrm{O}_{18}(\mathrm{NO})\right]$ with $\mathrm{N}_{2} \mathrm{H}_{4} \cdot 2 \mathrm{HCl}$ in a mixture of methanol and acetonitrile yields the four-electron reduced nitrosyl 166 decamolybdate $\left[\mathrm{Mov}_{4}^{\mathrm{V}} \mathrm{Mo}_{5}{ }_{5} \mathrm{O}_{24}(\mathrm{OMe})_{7}\left(\mathrm{Mo}{ }^{\prime \prime} \mathrm{NO}\right)\right]^{2-} \cdot{ }^{51}$ 
a Mechanism of UV-induced $\left[\mathrm{Mo}_{7} \mathrm{O}_{24}\right]^{6 \cdot}$ reduction

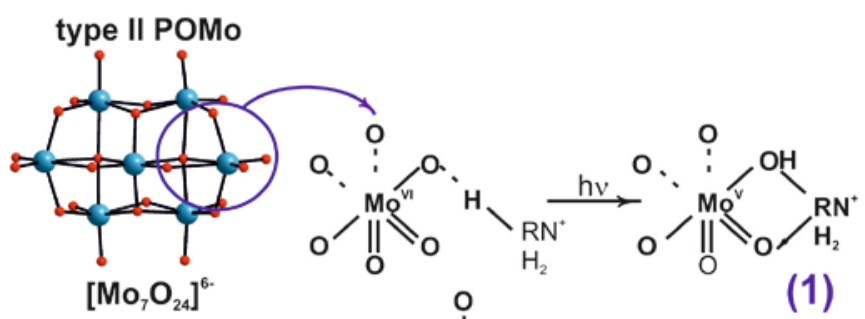

(1) $+\mathrm{H}_{2} \mathrm{O} \longrightarrow$

$(1) \longrightarrow\left[\dot{N H}_{2} \mathrm{R}\right]^{+}+{ }_{\mathrm{O}}^{\mathrm{O}}=\prod_{\mathrm{O}}^{\mathrm{Mov}}$

$\mathrm{Mo}^{\mathrm{v}} \mathrm{Mo}^{\mathrm{v}}$
(1)

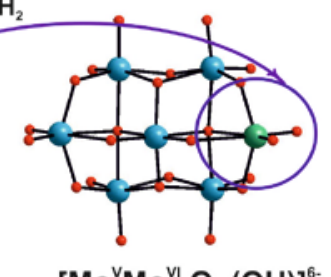

$\left[\mathrm{Mo}^{\mathrm{V}} \mathrm{Mo}^{\mathrm{v}}{ }_{6} \mathrm{O}_{23}(\mathrm{OH})\right]^{6 \cdot}$

b Formation of $\left[\mathrm{Mo}_{4}^{\mathrm{v}}{ }_{4} \mathrm{Mo}^{\mathrm{vv}}{ }_{4} \mathrm{O}_{24}\right]^{4}$ from $\alpha$-octamolybdate

type II POMo

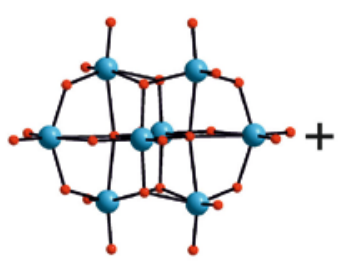

$\alpha-\left[\mathrm{Mo}_{8}^{\mathrm{vi}} \mathrm{O}_{26}\right]^{4}$

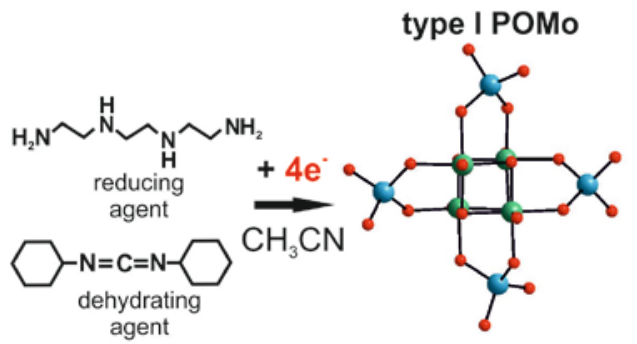

$\chi-\left[\mathrm{Mo}_{4}^{\mathrm{v}}{ }_{4} \mathrm{Mo}^{\mathrm{v}_{\mathrm{i}}} \mathrm{O}_{24}\right]^{4}$

$\mathrm{Mo}^{\mathrm{v}} \mathrm{Mo}^{\mathrm{v}}$

c Formation of $\left[\mathrm{H}_{2} \mathrm{Mo}_{7}^{\mathrm{V}} \mathrm{Mo}^{\mathrm{vi}}{ }_{12} \mathrm{O}_{52}\right]^{10-}$ from orthomolybdate
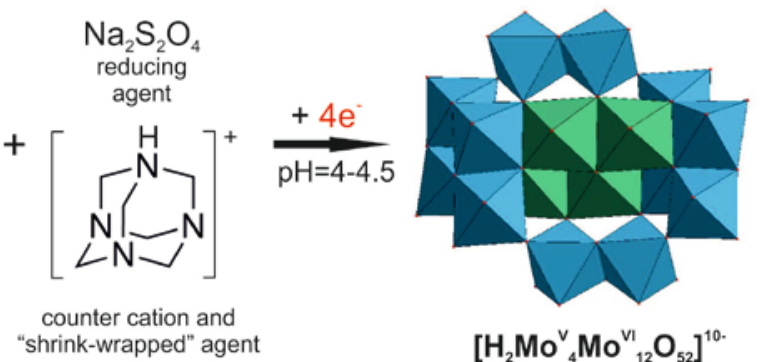

$\left[\mathrm{H}_{2} \mathrm{Mo}_{4}^{\mathrm{V}}{ }_{4} \mathrm{Mo}^{\mathrm{v}}{ }_{12} \mathrm{O}_{52}\right]^{10 \cdot}$

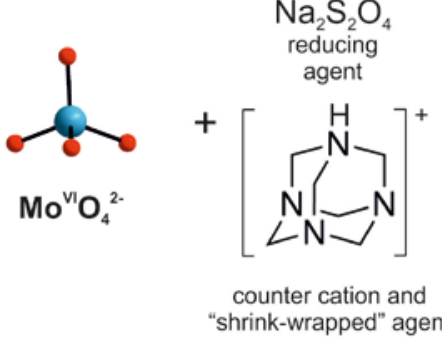

$\mathrm{Mov}^{\mathrm{v}} \mathrm{O}_{6}$

$\mathrm{Mo}^{\mathrm{v}} \mathrm{O}_{6}$

Figure 2 | Schematic representation of reduced isopolymolybdates formation. a | UV-induced reduction of 171 heptamolybdate. ${ }^{21,22} \mathbf{b}$ | Formation of the reduced $x$-type octomolybdate starting from $\alpha$-octomolybdate. ${ }^{52} \mathbf{c} \mid$ Formation of 172 the "shrink-wrapped" anion $\left[\mathrm{H}_{2} \mathrm{Mo}_{4}{ }_{4} \mathrm{Mo}^{\mathrm{VI}}{ }_{12} \mathrm{O}_{52}\right]^{10-} .{ }^{54}$ 
174

175

176

177

178

179

180

181

182

183

184

185

186

187

188

189

190

191

192

193

194

195

196

197

198

199

200

201

202

203

204

205

206

207

208

209

The structure of decamolybdate is closely related to that of the well-known decatungstate $\left[\mathrm{W}_{10} \mathrm{O}_{32}\right]^{4-}(\mathrm{FIG} 1, \mathrm{a})$ and consists of two halves of five edge-sharing octahedral connected through four quasi-linear Mo-O-Mo bridges. The Hückel calculations demonstrate that the "blue" electrons are circulating around the eight equatorial molybdenum sites as the delocalization is strongly favored by the quasi-linear M-O-Mo bridges. ${ }^{51}$

In 1993, Khan and co-workers were the first to obtain $\left[\mathrm{Me}_{2} \mathrm{NH}_{2}\right]_{6}\left[\mathrm{H}_{2} \mathrm{Mo}^{\mathrm{V}}{ }_{12} \mathrm{O}_{28}(\mathrm{OH})_{12}\left(\mathrm{Mo}^{\mathrm{VI}} \mathrm{O}_{3}\right)_{4}\right]$ by hydrothermal synthesis starting from $\mathrm{Na}_{2} \mathrm{MoO}_{4}, \mathrm{MoO}_{3}, \mathrm{Mo}, \mathrm{C}\left(\mathrm{CH}_{2} \mathrm{OH}\right)_{4},\left(\mathrm{Et}_{4} \mathrm{~N}\right) \mathrm{Cl}, \mathrm{Me}_{3} \mathrm{NH}$ and $\mathrm{H}_{2} \mathrm{O}^{55}$ The high degree of reduction of the central $\varepsilon$-Keggin (BOX 1) core $\left\{\mathrm{Mo}^{\mathrm{V}}{ }_{12} \mathrm{O}_{40}\right\}$ significantly increases the basicity of the oxygen atoms on the surface, which allows the aggregation of four electrophilic $\left\{\mathrm{Mo}^{\mathrm{V}} \mathrm{O}_{3}\right\}$ units. The remarkable flexibility of the host $\varepsilon$-Keggin cage is demonstrated by encapsulation of two protons. Later Yamase et al. showed that $\left[\mathrm{H}_{2} \mathrm{Mo}^{\mathrm{V}}{ }_{12} \mathrm{O}_{28}(\mathrm{OH})_{12}\left(\mathrm{Mo}^{\mathrm{VI}} \mathrm{O}_{3}\right)_{4}\right]^{6-}$ can also be formed by reduction in tumor cells from heptamolybdate and confirmed their prediction by long-term photolysis of $\left[{ }^{\prime} \mathrm{PrNH}_{3}\right]_{6}\left[\mathrm{Mo}_{7} \mathrm{O}_{24}\right] \cdot 3 \mathrm{H}_{2} \mathrm{O}$ in aqueous solutions at $\mathrm{pH}$ 5-6 yielding the same electron rich anion. ${ }^{38,53}$ $\left[\mathrm{H}_{2} \mathrm{Mo}_{12}^{\mathrm{V}} \mathrm{O}_{28}(\mathrm{OH})_{12}\left(\mathrm{Mo}^{\mathrm{V} / \mathrm{O}_{3}}\right)_{4}\right]^{6-}$ depressed the proliferation of human cancer cells such as AsPC-1 $\left(\mathrm{IC}_{50}=175 \mu \mathrm{g} \cdot \mathrm{ml}^{-1}\right)$ pancreatic and MKN-45 $\left(\mathrm{IC}_{50}=40 \mathrm{\mu g} \cdot \mathrm{ml}^{-1}\right)$ gastric cells in vitro and in vivo. ${ }^{39}$ Considering the possibility of photoreduced product formation in biological systems some of the anti-tumour activity of heptamolybdate can probably be traced back to its reduced species. ${ }^{39}$

The controlled hydrothermal oxidization of the triangular incomplete cuboidal $\left[\mathrm{Mo}^{\mathrm{IV}}{ }_{3} \mathrm{O}_{4}\left(\mathrm{H}_{2} \mathrm{O}\right)_{9}\right]^{4+}$ precursor in acidic solution, which was synthesized according to Cotton procedure, ${ }^{56}$ yielded the mixed-valence $\mathrm{Mo}^{\mathrm{IV}}-\mathrm{Mo}^{\mathrm{VI}}$ $\left[\mathrm{H}_{4} \mathrm{Mo}_{6}{ }_{6}^{\mathrm{IV}} \mathrm{Mo}_{7}^{\mathrm{VI}} \mathrm{O}_{36} \mathrm{Py}_{6}\right] \cdot \mathrm{H}_{2} \mathrm{py}_{3} \cdot 2 \mathrm{H}_{2} \mathrm{O}$ (py - pyridine), in which the anion possesses a $\beta$-Keggin structure with two $\left[\mathrm{Mo}^{\mathrm{IV}}{ }_{3} \mathrm{O}_{4}\right.$ ] fragments. ${ }^{57}$ The described anion exhibits Mo-Mo distances ranging from 2.5131(9) to 2.5318(9) $\AA$, which is unusually short for POMos. These short distances are unequivocally indicative of the existence of two Mo-Mo bonded $\left[\mathrm{Mo}^{\mathrm{IV}}{ }_{3} \mathrm{O}_{4}\right.$ ] units and in agreement with bond distances in $\left[\mathrm{Mo}_{3}^{\mathrm{IV}} \mathrm{O}_{4}\left(\mathrm{H}_{2} \mathrm{O}\right)\right]^{4+}$. The only known polyoxoanion with $\mathrm{Mo}^{\mathrm{IV}}$ centres is $\left[\mathrm{H}_{4} \mathrm{Mo}_{6}{ }_{6} \mathrm{Mo}^{\mathrm{VI}}{ }_{7} \mathrm{O}_{36} \mathrm{Py}_{6}\right]^{2-}$ and it has six terminal pyridine groups stabilizing the six $\mathrm{Mo}^{\mathrm{iv}}$ ions. $^{57}$

\section{Isopolytungstates}

Among the highly diverse class of isopolytungstates, decatungstate $\left[\mathrm{W}^{\mathrm{V} /}{ }_{10} \mathrm{O}_{32}\right]^{4^{-}}$and metatungstate $\left[\mathrm{H}_{2} \mathrm{~W}^{\mathrm{V}}{ }_{12} \mathrm{O}_{40}\right]^{6-}$ are most susceptible to electron acceptance. Metatungstate demonstrated remarkable electron storage capacity as it can accommodate up to 24 electrons. ${ }^{58}$ Decatungstate can accept a maximum of two electrons. Up to now eight reduced isopolytungstates (IPTs), which accepted between one and up to six electrons, were crystallized and investigated by singlecrystal XRD (TABLE S1).

One-electron reduction of the Lindqvist anion $\left[\mathrm{W}_{6}{ }_{6}{ }_{19} \mathrm{O}_{19}\right]^{2-}$. Reduced IPTs of the Lindqvist-type anion with one accepted electron $\left[\mathrm{W}^{\mathrm{V}} \mathrm{W}_{5}^{\mathrm{V}} \mathrm{O}_{19}\right]^{3-}$ were synthesized hydrothermally in the presence of metallic $\mathrm{V}$ or Mo as reducing agent. ${ }^{58}$ The existence of the reduced tungsten sites was confirmed by manganometric titrations. ${ }^{59}$ EPR analysis showed that the extra electron in $\left[\mathrm{W}^{\mathrm{V}} \mathrm{W}_{5}^{\mathrm{V}}{ }_{5} \mathrm{O}_{19}\right]^{3-}$ is delocalized over all six $\mathrm{W}$ centers via intramolecular electron hopping between the metal centers resulting in a rapid conversion of $-\mathrm{W}^{\mathrm{V}}-\mathrm{O}-\mathrm{W}^{\mathrm{V}}-$ into $-\mathrm{W}^{\mathrm{V}}-\mathrm{O}-\mathrm{W}^{\mathrm{V}}-$ and so on ${ }^{48,59}$ Another procedure to obtain the reduced Lindqvist-type IPT is the synthesis of the electron donor-acceptor complex $(\mathrm{CpFeCp})_{3}\left[\mathrm{~W}^{\mathrm{V}} \mathrm{W}_{5}^{\left.\mathrm{V}{ }_{5} \mathrm{O}_{19}\right]}\left(\mathrm{CpFeCp}=\mathrm{Fe}\left(\mathrm{C}_{5} \mathrm{H}_{5}\right)_{2}\right)\right.$ from orthotungstate $\mathrm{WO}_{4}{ }^{2-}$ and ferrocene $\mathrm{Fe}\left(\mathrm{C}_{5} \mathrm{H}_{5}\right)_{2}$ with no other reducing agent demonstrating that ferrocene acts as an effective agent to reduce $W^{\mathrm{VI}}$ to $\mathrm{W}^{\mathrm{V}}{ }^{60}$ 

with two non-exchangeable protons in a tetrahedral cavity, which is formed by four trinuclear capping units. In 1976, Launay showed that metatungtate $\left[\mathrm{H}_{2} \mathrm{~W}^{\mathrm{V} 1}{ }_{12} \mathrm{O}_{40}\right]^{6-}$ can be reduced by controlled potential electrolysis to yield the brown form. ${ }^{58}$ In these brown compounds $n$ (number of electrons introduced) is a multiple of 6 , such as in the following species $\mathrm{H}_{8}\left[\mathrm{H}_{2} \mathrm{~W}_{12} \mathrm{O}_{40}\right]^{4-}$ $(n=6), \mathrm{H}_{18}\left[\mathrm{H}_{2} \mathrm{~W}_{12} \mathrm{O}_{40}\right](n=12)$ and $\mathrm{H}_{36}\left[\mathrm{HW}_{12} \mathrm{O}_{40}\right]^{5+}(n=24)$, which could be isolated as solids. ${ }^{58,61,62}$ According to spectral and electrochemical properties, it was suggested that the total reduction process involves the transfer of 6 electrons and 6 protons, which is consistent with the localisation of the accepted electrons within a single trinuclear cap $\mathrm{W}^{\mathrm{IV}}{ }_{3}$, where the terminal oxo ligands are protonated to aqua ligands: $\left(\mathrm{W}^{\mathrm{VI}}=\mathrm{O}\right)_{3}+6 \mathrm{e}^{-}+6 \mathrm{H}^{+} \rightarrow\left(\mathrm{W}^{\mathrm{IV}} \leftarrow \mathrm{OH}_{2}\right)_{3}{ }^{63}$ with the $\alpha$-Keggin (BOX 1) anion $\mathrm{H}_{n}\left[\left\{\mathrm{~W}^{\mathrm{IV}}{ }_{3}\left(\mathrm{OH}_{2}\right)_{3}\right\} \mathrm{W}^{\mathrm{V}}{ }_{9} \mathrm{O}_{34}(\mathrm{OH})_{3}\right]^{(5-n)-}(\mathrm{n}=1,2)$ and ${ }^{183} \mathrm{~W}^{-\mathrm{NMR}^{17}}$ and XPS investigations ${ }^{61}$. The trinuclear caps $\mathrm{W}_{3}^{\mathrm{IV}}$ of the Keggin structure are proposed to be reduced sequentially. ${ }^{63}$ The $6 \mathrm{e}^{-}$reduced anion $\left[\mathrm{H}_{2}\left\{\mathrm{~W}_{3}^{\mathrm{IV}}\left(\mathrm{OH}_{2}\right)_{3}\right\} \mathrm{WV}_{9}^{\mathrm{VI}} \mathrm{O}_{34}(\mathrm{OH})_{3}\right]^{3-}$ can undergo condensation in aqueous solution between $\mathrm{pH}=4$ and 6.5 forming the highlynuclearity reduced species $\left[\left(\mathrm{XO}_{4}\right) \mathrm{W}_{3}^{\mathrm{IV}} \mathrm{W}_{17}^{\mathrm{VI}} \mathrm{O}_{62} \mathrm{H}_{\mathrm{x}}\right]^{\mathrm{y}-}\left(\mathrm{X}=\mathrm{H}_{2}{ }^{2+}, \mathrm{B}^{3+}\right) \cdot{ }^{65}$

The 24-electron reduced POT $\left(\mathrm{NH}_{4}\right)_{6}\left[\mathrm{H}_{2} \mathrm{~W}^{\mathrm{VI}}{ }_{12} \mathrm{O}_{40}\right]$ yields a fuel cell electrocatalyst towards the oxidation of hydrogen in acid electrolyte. ${ }^{66}$ This activity may be caused by either the presence of $6 \mathrm{~d}$ vacant orbitals similar to the conventional $\mathrm{Pt}$ catalysts or reactivity of non-acidic protons in the structure. Moreover, electron- "tungsten brown" metatungstates with reduced three $\mathrm{W}^{\mathrm{IV}}$ caps exhibit some electrocatalytic activity.

One and two-electron reduction in catalytic active decatungstates. Decatungstate $\left[\mathrm{W}^{\mathrm{VI}}{ }_{10} \mathrm{O}_{32}\right]^{4-}$ is well-known for its high photocatalytic activity. ${ }^{67}$ The structure of $\left[\mathrm{W}^{\mathrm{VI}}{ }_{10} \mathrm{O}_{32}\right]^{4-}$ consists of two lacunary Lindquist $\left[\mathrm{W}_{5} \mathrm{O}_{14}\right]^{2-}$ fragments linked by four corner-sharing oxygens with an unusually wide-OAW angle of $178^{\circ}$

(FIG. 1 a). ${ }^{68}$ The one-electron-reduced complex $\left[\mathrm{W}^{\mathrm{V}} \mathrm{W}^{\mathrm{V} /}{ }_{9} \mathrm{O}_{32}\right]^{5-}$ was prepared by controlled-potential electrolysis of $\left[\mathrm{W}_{10} \mathrm{O}_{32}\right]^{4-}$ in $\mathrm{N}, \mathrm{N}$-dimethylformamide (DMF). ${ }^{69}$ Long-term UV irridation of the oxidized parent decatungstate leads to the formation of a mixture of protonated one- and two-electron reduced species, namely $\left[\mathrm{HW}^{\mathrm{V}} \mathrm{W}_{9}^{\mathrm{V}}{ }_{9} \mathrm{O}_{32}\right]^{4-}$ and $\left[\mathrm{H}_{2} \mathrm{~W}_{2}^{\mathrm{V}} \mathrm{W}^{\mathrm{V}}{ }_{8} \mathrm{O}_{32}\right]^{4-}$, respectively. ${ }^{70,71}$ The unprotonated two-electron reduced

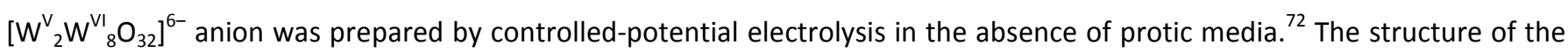
that in both the one- and two-electron reduced anions, $\left[\mathrm{W}^{\mathrm{V}} \mathrm{W}^{\mathrm{V} /} \mathrm{O}_{32}\right]^{5-}$ and $\left[\mathrm{W}^{\mathrm{V}}{ }_{2} \mathrm{~W}^{\mathrm{V} /}{ }_{8} \mathrm{O}_{32}\right]^{6-}$, repsecitvely, the extra electrons are principally located at the equatorial sites (four edge-shared within a plane octahedra) (FIG. 1 a).

Decatungstates have been successfully applied by Hill and co-workers ${ }^{27,73,74}$ during the homogeneous photocatalytic oxidation of various organic substrates, such as alkanes, alkenes, alcohols, and amines due to the wide range of redox potentials of $\left\{\mathrm{W}_{10} \mathrm{O}_{32}\right\}$, as well as the reversibility in their multielectron reductions. Mechanistic studies have shown that the same one-electron reduced form of decatungstate $\left[\mathrm{HW}^{\mathrm{V}} \mathrm{W}_{9}^{\mathrm{V}}{ }_{9} \mathrm{O}_{32}\right]^{4-}$ is formed during the catalytic oxidation, which may react quantitatively with oxygen to form hydrogen peroxide and/or organic hydroperoxides as final products. ${ }^{75-77}$

\section{Isopolyvanadates}


mostly of a variety of vanadium alkoxide structures. Up to now 22 reduced IPVs, which accept between one and six electrons, were crystallized and investigated by single-crystal XRD (TABLE S1).

Reduced and organically functionalized hexavanadates. The Lindqvist vanadium core $\left\{\mathrm{V}_{6} \mathrm{O}_{19}\right\}$ (FIG. $1 \mathrm{a}$ ) is unstable due to the high charge/volume ratio. The most high-valent $\left(V^{V}\right)$, mixed-valent $\left(V^{I V} / V^{V}, V^{\prime \prime \prime} / V^{I V}\right)$ or fully reduced $\left(V^{I V} ; V^{I V} / V^{\prime \prime \prime}\right)$ hexavanadates were obtained as alkoxo-derivatives, in which varying numbers of double bridged oxo groups of $\left\{\mathrm{V}_{6} \mathrm{O}_{19}\right\}$ are replaced by alkoxy oxygen donors of polyol ligands (FIG. 1 a). ${ }^{78}$ Zubieta et al. were successful in synthesizing a variety of hexavanadate derivatives with the help of trisalkoxo $\mu$-bridging moieties revealing a rich class of $V^{\mathrm{IV}} / \mathrm{V}^{\vee}$ mixed valence compounds. ${ }^{79-81}{ }^{T h e}$ oxovandium clusters can be formed under solvothermal conditions: 1) by a comproportionation reaction of precursors with vanadium atoms in oxidation states $+3\left(\mathrm{~V}_{2} \mathrm{O}_{3}\right)$ and $\left.+5\left(\mathrm{VO}_{3}{ }^{-}, \mathrm{V}_{2} \mathrm{O}_{5}\right)^{80} ; 2\right)$ by reducing the fully oxidized compound with reducing agents (1,2-diphenylhydrazine, $\mathrm{N}_{2} \mathrm{H}_{5} \mathrm{OH}$ etc. $)^{79,82}$; 3) by reaction of $\mathrm{VO}(\mathrm{OR})_{3}\left(\mathrm{R}=\mathrm{Me}\right.$, Et, Bu) with $\mathrm{BH}_{4}{ }^{-}$in methanol. ${ }^{83-87}$ The solvothermal reaction of $\mathrm{VOSO}_{4}$ with p-tert-butylcalix[4]arene in methanol under anaerobic conditions yielded the $\mathrm{V}^{\prime \prime \prime} / \mathrm{V}^{\mathrm{IV}}$ hexavanadate $\left[\mathrm{V}^{\mathrm{III}} \mathrm{V}_{5}{ }_{5} \mathrm{O}_{6}\left(\mathrm{OCH}_{3}\right)_{8}(\mathrm{calix})\left(\mathrm{CH}_{3} \mathrm{OH}\right)\right]^{-88}$. In each mixed-valence or fully reduced cluster six vanadium nuclei surround one oxo anion forming a nearly regular octahedron (FIG. 1 a). EPR studies and DFT calculations showed that the d-electrons of the $V^{\mathrm{IV}}$ nuclei can be extensively delocalized in the highly symmetrical $\left\{\mathrm{V}_{6} \mathrm{O}_{19}\right\}$ hexavanadate core. ${ }^{83,86}$ The magnetic exchange interactions between unpaired d-electrons in the Lindqvist core-structure are prone to geometric spin frustration. ${ }^{79}$ Recently, Matson et al. reported the synthesis and characterization of iron-substituted Lindqvist type alkoxo-vanadates $\left[\mathrm{V}_{3}^{\mathrm{IV}} \mathrm{V}_{2}^{\mathrm{V}} \mathrm{O}_{6}\left(\mathrm{OCH}_{3}\right)_{12} \mathrm{Fe}{ }^{\mathrm{III}} \mathrm{X}\right](\mathrm{X}=\mathrm{Cl} \text {, OTf, OTf - trifluoromethylsulfonate })^{89}$, which are capable to accept up to four electrons while remaining the +3 oxidation state of the iron atom. ${ }^{90}$

$\mathrm{Xu}$ et al. have studied the influence of five functionalized hexavanadates, including one reduced IPVs $\left[\mathrm{V}_{3}{ }_{3} \mathrm{~V}_{3}^{\mathrm{V}} \mathrm{O}_{10}(\mathrm{OH})_{3}\left(\left(\mathrm{OCH}_{2}\right)_{3} \mathrm{CNO}_{2}\right)_{2}\right]^{91}$, on $\mathrm{Na}^{+} / \mathrm{K}^{+}$-ATPase activity in vitro. ${ }^{40}$ Dose dependent $\mathrm{Na}^{+} / \mathrm{K}^{+}$-ATPase inhibition was obtained for all investigated compounds, however, the obtained results indicate that the most potent inhibitor is the reduced compound $\left(I C_{50}=(1.8 \pm 0.5) \cdot 10^{-5} \mathrm{~mol} \cdot \mathrm{L}^{-1}\right)$.

Classically functionalized and "wheel"-type decavanadates. Exploiting the hydrothermal synthetic procedure as in the case of alkoxohexavanadatates, Zubieta and co-workers obtained clusters based on the fully $\left\{\mathrm{V}^{\mathrm{IV}}{ }_{10} \mathrm{O}_{28}\right\}$ or partially $\left\{\mathrm{V}^{\mathrm{IV}} \mathrm{V}^{\mathrm{V}}{ }_{2} \mathrm{O}_{28}\right\}$ reduced cores with variable numbers of doubly and triply bridging oxo groups being replaced by the alkoxy oxygen donors of tris-alkoxy ligands (FIG. 1 a)..$^{81,86}$

In 1982, Heitner-Wirguin and co-workers firstly reported on the synthesis and structure of the mixed-valence wheellike decavanadate anion $\left[\left(\mathrm{V}^{\mathrm{IV}} \mathrm{O}\right)_{2} \mathrm{~V}_{8}^{\mathrm{V}} \mathrm{O}_{24}\right]^{4-}$, which was obtained by the hydrolytic dissociation of $\mathrm{V}^{\mathrm{IV}} \mathrm{O}(\mathrm{acac})_{2}$ in methylene chloride or chloroform in the presence of $\mathrm{Cu}^{\prime \prime}(\mathrm{acac})_{2}$ or $\mathrm{Zn}$ "(acac) ${ }_{2}{ }^{92.93}$ Later, an improved synthetic procedure, which does not require the use of $\mathrm{Cu}^{\prime \prime}(\mathrm{acac})_{2}$ or $\mathrm{Zn}{ }^{\prime \prime}(\mathrm{acac})_{2}$ anymore, was reported together with a magnetic susceptibility study by Baxter and Wolczanski. ${ }^{94,95}$ The structure of $\left[\left(\mathrm{V}^{\mathrm{V}} \mathrm{O}\right)_{2} \mathrm{~V}_{8}^{\mathrm{V}} \mathrm{O}_{24}\right]^{4-}$ is absolutely different from $\mathrm{d}^{0}$ decavanadate $\left[\mathrm{V}_{10}^{\mathrm{V}} \mathrm{O}_{28}\right]^{6-}$ and consist of the macrocyclic $\left[\mathrm{V}^{\mathrm{V}} \mathrm{O}_{3}\right]_{8}^{8-}$ ligand, which binds two vanadyl cations $\left[\mathrm{V}^{\mathrm{IV} O}\right]^{2+}$ at the center. The reaction of the macrocyclic $\left[\mathrm{V}^{\mathrm{V}} \mathrm{O}_{3}\right]_{8}^{8-}$ ligand with $\mathrm{Cu}^{\prime \prime}$ affords a heteropoly complex, namely $\left[\mathrm{Cu}_{2}{ }_{2} \mathrm{~V}_{8}^{\mathrm{V}} \mathrm{O}_{24}\right]^{4-}$, of which structure is similar to that of $\left[\left(\mathrm{V}^{\mathrm{V}} \mathrm{O}\right)_{2} \mathrm{~V}_{8}^{\mathrm{V}} \mathrm{O}_{24}\right]^{4-} .96$ The second synthetic way to obtain the wheel cluster $\left[\left(\mathrm{V}^{\mathrm{IV}} \mathrm{O}\right)_{2} \mathrm{~V}_{8}^{\mathrm{V}} \mathrm{O}_{24}\right]^{4-}$ is the condensation of $\left[\mathrm{V}_{5}^{\mathrm{V}} \mathrm{O}_{14}\right]^{3-}$ upon irradiation with visible light. ${ }^{97,98}$

\section{Reduced heteropolyanions}




\section{Box $1 \mid$ Keggin structure and its isomers}

The Keggin structure was first reported in 1933 during the analysis of 12-tungstophosphoric acid ${ }^{255}$ and has become the de facto emblem of POM chemistry. The bulk of publications in this field are devoted to Keggin type anions. This ion has the general formula $\left[\mathrm{XM}_{12} \mathrm{O}_{40}\right]^{\mathrm{n}-}$, where $\mathrm{X}$ is a heteroatom that is coordinated by four $\mathrm{O}$ atoms leading to its tetrahedral geometry, $M=M o$ or $W$, charges range from $n=2\left(X=S^{V I}{ }^{256}\right)$ to $n=7\left(X=C u^{\prime 257}\right)$. Investigations of the Keggin structure revealed five isomers, each resulting from $60^{\circ}$ rotation of one, two, three and four $\left\{\mathrm{M}_{3} \mathrm{O}_{13}\right\}$ triad units, respectively, leading to the $\alpha, \beta, \gamma, \delta$ and $\varepsilon$ isomers as reported by Baker and Figgis. ${ }^{258}$ The arrangements of the $\mathrm{M}_{3} \mathrm{O}_{13}$ triads affect the molecular orbital energies and the distances between metal centers, which also in turn affect the electrostatic repulsion. Thus, the stability of fully oxidized Keggin anions decreases in the order $\alpha<\beta<\gamma<\delta<\varepsilon$. The reduced clusters behave differently. The $\beta$ form becomes the most stable isomer after the acceptance of the second and fourth electron as the LUMO is lower than that in the $\alpha$ form. ${ }^{259}$ The $\psi$ isomer also has a low LUMO and gains stability upon reduction, but not enough to be competitive with the $\beta$ isomer. The other isomers, $\delta$ and $\varepsilon$, are much more unstable than $\alpha$ or $\beta$ in any reduction state and require transition metal support. ${ }^{259-261}$ Remarkably, in reduced Keggin POMs resistance to addenda atom substitution can increase due to the additional energy factor of orbital overlaps for the delocalization of the added electrons. Also addenda substitution for a lower charged metal increases total negative charge of the already reduced anion, which can lead to its instability. A general way to stabilize the Keggin anions with higher negative charges after reduction is to introduce electrophilic capping groups such as $\left\{\mathrm{V}^{\mathrm{V}} \mathrm{O}\right\}^{3+}$ or $\left\{\mathrm{V}^{\mathrm{IV}} \mathrm{O}\right\}^{2+}$. The structures, which are formed after such capping, have become known as "pseudo-Keggin" structures.

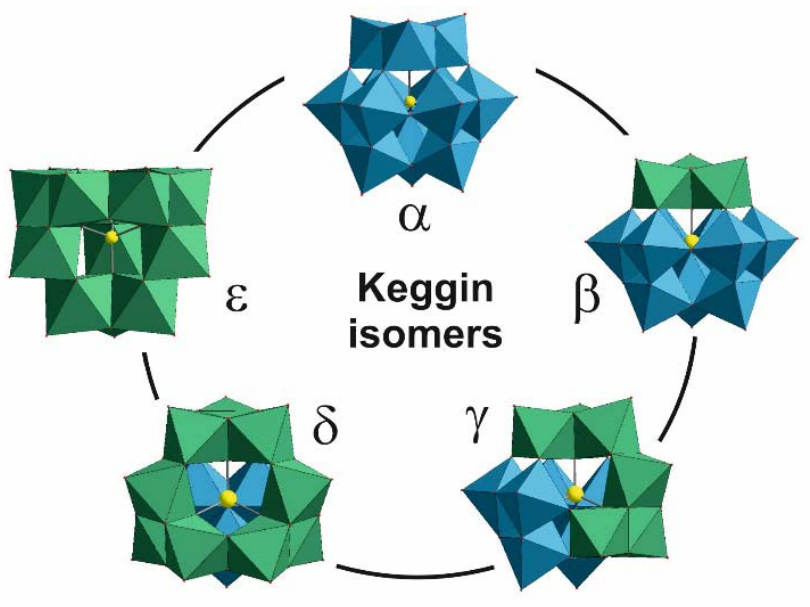

Electron accepting properties of Keggin-type polyoxomolybdates. The synthesis of the heteropoly acid from orthophosphate $\mathrm{PO}_{4}{ }^{3-}$ and molybdate $\mathrm{MoO}_{4}{ }^{2-}$ under acidic conditions and its subsequent reduction to form an intensely coloured phosphomolybdenum blue $\left[\mathrm{PMo}_{n}{ }_{n} \mathrm{Mo}^{\mathrm{VI}}{ }_{(12-n)} \mathrm{O}_{40}\right]^{(3+n)-}$ was firstly reported by Scheele in 1783 . However, its discovery is widely attributed to Berzelius in $1826 .{ }^{15}$ Especially the molybdate blues have long been used for colorimetric determination of trace levels of elements that readily form Keggin anions, e.g. for analysis of phosphates and silicates. 
So far seventeen reduced POMos of Keggin structure, which accept between one and up to twelve electrons, were crystallized and investigated by single-crystal XRD (TABLE S2).

The redox behavior of Keggin-type POMos is highly acid-dependent. ${ }^{10,99}$ Launary et al. reported on the pH effect of the first three reversible two-electron reductions of $\left[\mathrm{SiMo}^{\mathrm{VI}}{ }_{12} \mathrm{O}_{40}\right]^{4-}$. The two- electron waves are shifted to more negative potential when the $\mathrm{pH}$ is higher and they are eventually split into one-electron waves. This takes place at $\mathrm{pH} 2.4$ for the first, $\mathrm{pH} 9.5$ for the second and $\mathrm{pH} 13$ for the third wave giving rise to the formation of $\left[\mathrm{SiMo}^{\mathrm{V}} \mathrm{Mo}^{\mathrm{VI}}{ }_{11} \mathrm{O}_{40}\right]^{5-},\left[\mathrm{SiMo}_{2}{ }_{2} \mathrm{Mo}^{\mathrm{VI}}{ }_{10} \mathrm{O}_{40}\right]^{6-}$ and $\left[\mathrm{SiMo}_{3}^{\mathrm{V}} \mathrm{MoO}_{9}^{\mathrm{VI}} \mathrm{O}_{40}\right]^{4-}$, respectively. ${ }^{48,100}$

The reduced $\alpha$ - and $\beta$-Keggin POMos can be synthesized electrochemicaly ${ }^{101,102}$ or by hydrothermal reactions ${ }^{21,105-1122} 25$, 31, 103-107 Reduced POMos exhibiting the $\varepsilon$-Keggin structure can only be synthesized hydrothermally with the support of TM"units (TM - transition metal, e.g. $\mathrm{Ni}^{\mathrm{i}}, \mathrm{CO}^{\prime \prime}$ ). ${ }^{26,108-111}$ Organic ligands (e.g. 1,2-propanediamine) or reagents bearing a heteroatom (e.g. $\left.\mathrm{As}_{2} \mathrm{O}_{3}\right)^{109}$ can display reducing effects on the addenda atoms. A complex containing an $\varepsilon$-core is $\left[\mathrm{Na}\left(\mathrm{Mo}^{\mathrm{VI}} \mathrm{O}_{3}\right)_{4} \mathrm{Mo}_{12}^{\mathrm{V}}(\mathrm{OH})_{12} \mathrm{O}_{28}\right]^{7-}$ possessing Mo-capping units and a central cavity, which is capable of accommodating protons or metal cations. ${ }^{55}$ This compound was obtained in aqueous solution from heptamolybdate and phenylphosphonic acid with hydrazinium dichloride $\mathrm{N}_{2} \mathrm{H}_{4} \cdot 2 \mathrm{HCl}$ as reducing agent. The magnetic properties of electron-rich Keggin-type POMos were investigated and in the case of $\left[\mathrm{GeMo}_{8}^{\mathrm{V}} \mathrm{Mo}^{\mathrm{VI}}{ }_{4} \mathrm{O}_{40}\right]^{12-}$ and $\left[\left(\mathrm{As}^{\mathrm{V}} \mathrm{O}_{4}\right) \mathrm{Mo}_{8}^{\mathrm{V}} \mathrm{W}^{\mathrm{Vl}}{ }_{4} \mathrm{O}_{33}\left(\mu_{2}-\mathrm{OH}\right)_{3}\right]^{8-}$ the negative Weiss constants indicate the possible occurrence of weak antiferromagnetic interactions between the transition metal centers. ${ }^{109}$ On the other hand, the magnetic properties of the compound with fully reduced addenda atoms $\left[\mathrm{Mo}^{\mathrm{V}}{ }_{12} \mathrm{O}_{30}(\mu-\mathrm{OH})_{10} \mathrm{H}_{2}\left\{\mathrm{Ni}^{\prime \prime}{ }_{4}\left(\mathrm{H}_{2} \mathrm{O}\right)_{12}\right\}\right]$ (FIG. $3 \mathrm{a})^{26}$ are dominated by exchange interactions between the four $\mathrm{Ni}^{\prime \prime}$ centers, while the strong interactions between the $12 \mathrm{Mo}\left(4 \mathrm{~d}^{1}\right)$ centers result in six $\mathrm{Mo}^{\mathrm{V}}-\mathrm{Mo}^{\mathrm{V}}$ dumbbells with $-\mathrm{Wmo}$ single bonds as is the case $\operatorname{in}\left[\mathrm{Na}\left(\mathrm{Mo}^{\mathrm{VI}} \mathrm{O}_{3}\right)_{4} \mathrm{Mo}_{12}^{\mathrm{V}}(\mathrm{OH})_{12} \mathrm{O}_{28}\right]^{7-55}$

The Co"-capped $\varepsilon$-Keggin anion $\left[(\mathrm{Co} " \mathrm{bpy})_{2}\left(\mathrm{PMo}_{4}{ }_{4} \mathrm{Mo}^{\mathrm{V}}{ }_{8} \mathrm{O}_{40}\right)\right]^{3-}$ has been checked for catalyzing water oxidation to generate $\mathrm{O}_{2}$ under visible light irradiation using $\left[\mathrm{Ru}(\mathrm{bpy})_{3}\right]^{2+}$ as photosensitizer and $\mathrm{S}_{2} \mathrm{O}_{8}{ }^{2-}$ as the sacrificial electron acceptor. ${ }^{31}$ Although the stability of POMo under photocatalytic conditions was demonstrated by dynamic light scattering (DLS), extraction experiment, and UV-Vis and FT-IR spectroscopy, it should be noted that bipyridine and Co "'Co"-oxide, which can be formed under these conditions, are well established to be efficient water oxidation catalysts. A turnover number of up to $49 \mathrm{sec}^{-1}$ was observed by the authors, ${ }^{31}$ which shows that this reduced POMos could be an efficient visible light-driven catalysts for water oxidation. The photocatalytic water oxidation activity of $\left[(\mathrm{Co} " \mathrm{lbpy})_{2}\left(\mathrm{PMo}_{4}{ }_{4} \mathrm{Mo}^{\mathrm{VI}}{ }_{8} \mathrm{O}_{40}\right)\right]^{3-}$ resembles that of POMs with non- reduced addenda atoms. ${ }^{112}$

Nobel metal nanoparticles can be formed in water at room temperature in the presence of four electron-reduced Keggin POMo $\mathrm{H}_{7}\left[\beta-\mathrm{PMo}_{4}{ }_{4} \mathrm{Mo}^{\mathrm{VV}_{8}} \mathrm{O}_{40}\right]$ and are stable for several months. ${ }^{113-115}$ In this case the electron-rich POMos play the role of the reductant and stabilizer.

The salt of doubly reduced $\left[\mathrm{PMo}_{2}^{\mathrm{V}} \mathrm{Mo}^{\mathrm{VI}}{ }_{10} \mathrm{O}_{40}\right]^{5-}$ anion with benzimidazolium exhibited a dielectric anomaly, which was caused by electric dipole relaxation. ${ }^{116}$ This dipole relaxation can be explained by a hopping process of the blue electrons and a charge relaxation from a disproportionated structure to a fully delocalized structure due to distortion of the Keggin framework by intermolecular interaction.

POM-molecular cluster batteries based on $\left[\mathrm{PMo}^{\mathrm{VI}}{ }_{12} \mathrm{O}_{40}\right]^{3-}$ anion exhibit a large capacity of ca. $270(\mathrm{~A} \mathrm{~h}) / \mathrm{kg}$ in a voltage range between 1-5-4.0 $\mathrm{V}$ due to their ability to reversibly accept 24 -electrons during charging/discharging process. ${ }^{41}$ 
Electron accepting properties of Keggin-type polyoxotungstates. In 1960-1970 Pope and co-workers laid the foundation for the investigation of the reduction processes in Keggin-type heteropolytungstates (HPT). ${ }^{117,118}$ and unveiled the formation of heteropoly "browns" with $\mathrm{W}$ in the oxidation state $+4 .{ }^{17,18}$ They demonstrated that the electrons can be accepted by Keggin POTs $\left[\mathrm{XW}_{12} \mathrm{O}_{40}\right]^{\mathrm{n}-}\left(\mathrm{X}=\mathrm{P}^{\vee}, \mathrm{Si}^{\mathrm{IV}}, \mathrm{Fe}^{\mathrm{III}}, \mathrm{Co}^{\prime \prime}\right)$ without protonation until the total charge of the reduced species is-6 in acidic media and -8 in neutral media. Further reduction is then always accompanied by protonation keeping the overall ionic charge at -6 or -8. So far eleven reduced HPTs exhibiting the Keggin structure $\left\{\mathrm{XW}^{\mathrm{V} / \mathrm{V} I}{ }_{12} \mathrm{O}_{40}\right\}$, which accept between one and up to six electrons, were crystallized and investigated by single-crystal XRD (TABLE S2).

Reduced Keggin type POTs could be so far synthesized electrochemically ${ }^{123-125}$ 117-119 or under hydrothermal conditions. ${ }^{-106,120-123}$ One-electron reduced POTs were obtained at $\mathrm{pH}=4.3-5.5$, whereas the higher reduced electron-rich Keggin POTs were obtained at higher $\mathrm{pH}$. As previously noted the "blue" electrons do not alter the crystal structure of the parent POT anion. Detailed analysis of structural parameters of $\alpha-\left[\mathrm{CO}^{\prime \prime} \mathrm{W}^{\mathrm{VI}}{ }_{12} \mathrm{O}_{40}\right]^{6-}$ and $\alpha-\left[\mathrm{Co}^{\prime \prime} \mathrm{W}_{2}^{\mathrm{V}} \mathrm{W}^{\mathrm{VI}}{ }_{10} \mathrm{O}_{40}\right]^{8-}$ showed that except for a shortening of each centrat $\complement_{0}$ tetrahedral distance by $0.03 \AA$ and a consequent corresponding increase in

a

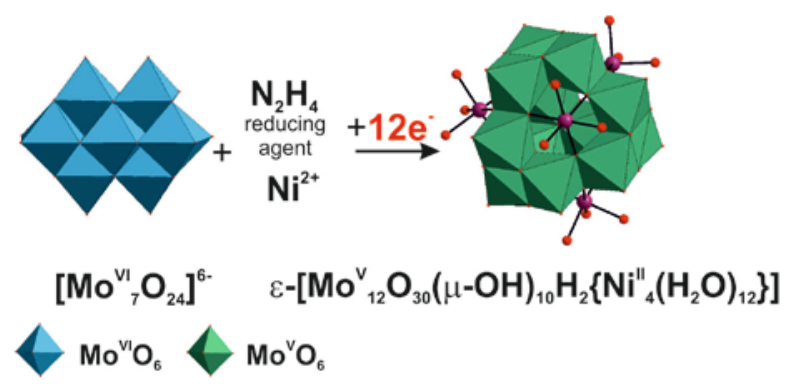

C

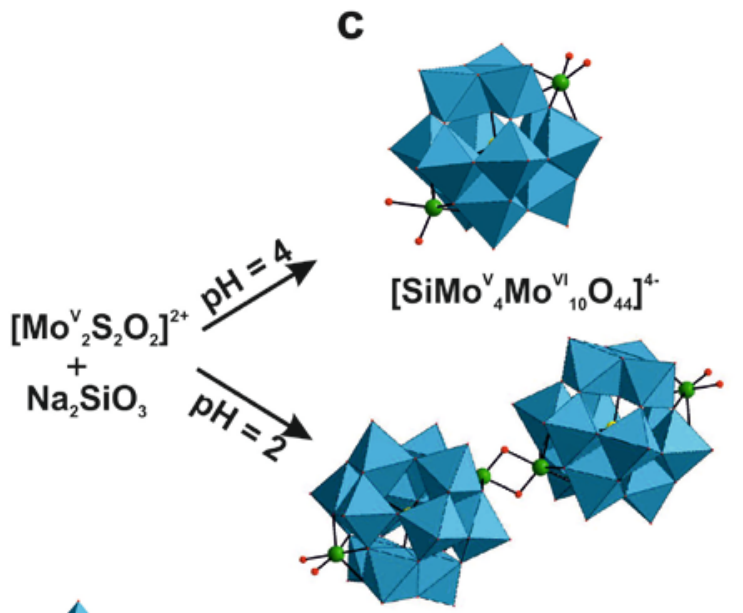

b

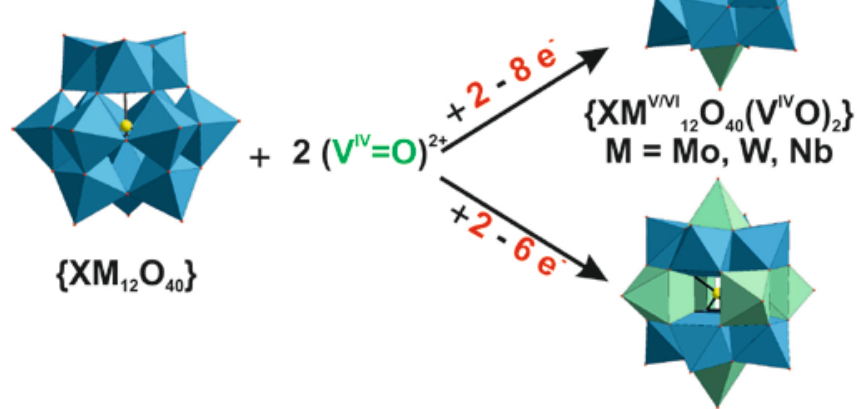

d $\quad\left\{\mathrm{XMo}^{\mathrm{V} / \mathrm{N}} \mathrm{V}^{\mathrm{V} / \mathrm{VI}} \mathrm{O}_{40}\left(\mathrm{~V}^{\mathrm{iV} O}\right)_{2}\right\}$

$$
\mathrm{Mo}^{\mathrm{v}} \mathrm{O}_{6} \odot \mathrm{Mo}^{\mathrm{v}} \quad\left[\mathrm{Si}_{2} \mathrm{Mo}^{\mathrm{v}}{ }_{14} \mathrm{Mo}^{\mathrm{vv}}{ }_{14} \mathrm{O}_{84}\left(\mathrm{H}_{2} \mathrm{O}\right)_{2}\right]^{6-}
$$

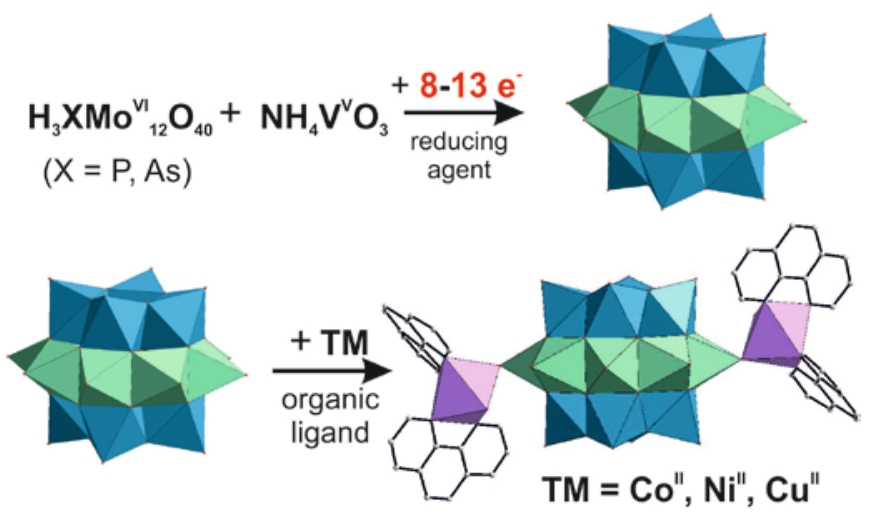

Figure 3 | Synthesis of electron-rich POMs based on the Keggin anion. a | Schematic representation of the formation process 
POMs formation. $\mathbf{c} \mid \mathrm{pH}$-depended formation of monomeric $\left[\mathrm{SiMo}_{4}^{\mathrm{V}} \mathrm{Mo}^{\mathrm{VV}}{ }_{10} \mathrm{O}_{44}\right]^{4-}$ and dimeric $\left[\mathrm{Si}_{2} \mathrm{Mo}_{14}^{\mathrm{V}} \mathrm{Mo}^{\mathrm{Vv}}{ }_{14} \mathrm{O}_{84}\left(\mathrm{H}_{2} \mathrm{O}\right)_{2}\right]^{6-}$ bicapped anions. ${ }^{152} \mathbf{d}$ |Schematic representation of the formation of transition metal supported tetra-capped anion (e.g. $\left[\mathrm{AsMo}{ }_{6}{ }_{6} \mathrm{Mo}_{2}{ }_{2} \mathrm{~V}^{\mathrm{IV}}{ }_{8} \mathrm{O}_{44}\right]^{5-}$ connected covalently with two $\left.\left\{\mathrm{Co}(\text { phen })_{2}\left(\mathrm{H}_{2} \mathrm{O}\right)\right\}\right) .{ }^{155}$

Using ${ }^{27} \mathrm{Al}$ NMR Hill et al. demonstrated the defined electron exchange between a fully oxidized $\alpha-\left[\mathrm{Al}^{\mathrm{III}} \mathrm{W}^{\mathrm{Vl}}{ }_{12} \mathrm{O}_{40}\right]^{5-}$ and

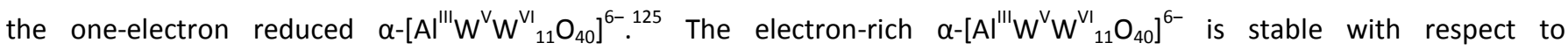
disproportionation, structural isomerization and hydrolysis (from $\mathrm{pH} 0$ to 7). In addition, it remains unprotonated over a wide $\mathrm{pH}$ range $(\mathrm{pH} 1.8$ to 7.5$)$ and is free of $\mathrm{Na}^{+}$ion pairing with $\mathrm{Na}^{+}(\mathrm{C}>1 \mathrm{M})$.

Stability of the $\left[\mathrm{SiW}_{3}^{\mathrm{IV}} \mathrm{W}^{\mathrm{VI}}{ }_{9} \mathrm{O}_{40}\right]^{10-}$ "brown" anion in acid solution depends on the nature of the Keggin isomer and decreases in the order $\alpha>\beta>\gamma$, which can be correlated with the structural modifications induced by rotation of the $\left\{\mathrm{W}_{3}^{\mathrm{IV}} \mathrm{O}_{13}\right\}$ groups. The $4 \mathrm{e}^{-}$blue anion $\left[\mathrm{SiW}_{4}^{\mathrm{V}} \mathrm{W}^{\mathrm{VI}}{ }_{8} \mathrm{O}_{40}\right]^{8-}$ is stable in acidic solution with the $\beta$-isomer being more stable than the corresponding $\alpha$ and $\gamma$ forms. ${ }^{126}$

Coronado and co-workers investigated the influence of the electron transfer on the magnetic properties of the twoelectron reduced $\left\{\mathrm{W}_{4} \mathrm{O}_{16}\right\}$ fragment of the $\alpha-\left[\mathrm{PW}_{2}^{\mathrm{V}} \mathrm{W}^{\mathrm{VI}}{ }_{10} \mathrm{O}_{40}\right]^{5-}$ anion. ${ }^{127}$ They showed that the electron transfer between edgesharing and corner-sharing $\mathrm{WO}_{6}$ octahedra have very close energy values and induce a large energy gap between the singlet ground state and the lowest triplet states. These data explain the diamagnetic properties of the mixed-valence Keggin ions reduced by two electrons and can be used for other electron-rich POM archetypes.

Neumann and co-workers have recently shown that $\mathrm{H}_{5}\left[\mathrm{PW}_{2}^{\mathrm{V}} \mathrm{W}^{\mathrm{V}}{ }_{10} \mathrm{O}_{40}\right]$ is a photoactive electron and proton donor by light-induced excitation of the intervalence charge transfer band. ${ }^{32}$ The reduced POT $\mathrm{H}_{5}\left[\mathrm{PW}^{\mathrm{V}}{ }_{2} \mathrm{WV}_{10}^{\mathrm{VI}} \mathrm{O}_{40}\right]$ was used to transfer electrons to the di-rhenium catalyst that catalyzes the selective reduction of $\mathrm{CO}_{2}$ to $\mathrm{CO}$.

The study of reoxidation of photoreduced $\left[\mathrm{PW}^{\mathrm{V}} \mathrm{W}^{\mathrm{VI}}{ }_{11} \mathrm{O}_{40}\right]^{4-}$ by hydrogen peroxide, peroxyacetic acid, peroxymonosulfate, peroxydisulfate and dioxygen $\left(\mathrm{O}_{2}\right)$ in the presence of the model pollutant 2-propanol under various conditions provide insight into POM-catalyzed redox reactions in water purification and selective redox applications. ${ }^{33} \mathrm{~A}$ unified chain reaction is proposed in which the rate-limiting step is outer-sphere one-electron transfer to oxidants yielding 'OX $\left({ }^{\circ} \mathrm{OH}, \mathrm{SO}_{4}{ }^{--}\right.$or $\left.\mathrm{CH}_{3} \mathrm{CO}_{2}{ }^{\circ}\right)$. The chain includes a number of $\left[\mathrm{PW}^{\mathrm{V}} \mathrm{W}^{\mathrm{VI}}{ }_{11} \mathrm{O}_{40}\right]^{4-}$-regenerating steps that, with some bulk oxidants, leads to further consumption of bulk oxidant and transformation of pollutant.

The conversions of the three types of olefins catalyzed by $\mathrm{NaCu}_{2}^{\prime}(\mathrm{tib})_{4}\left(\mathrm{H}_{2} \mathrm{O}\right)_{4}\left[\mathrm{H}_{2} \mathrm{PW}^{\mathrm{V}} \mathrm{W}^{\mathrm{VI}}{ }_{11} \mathrm{O}_{40}\right]\left[\mathrm{H}_{2} \mathrm{PW}^{\mathrm{VI}}{ }_{12} \mathrm{O}_{40}\right] \cdot 6 \mathrm{H}_{2} \mathrm{O}$ (tib 1,3,5-tris(1-imida-zolyl)benzene), are 98.3\% (thexene), 95.7\% (cyclo hexene), and 97.1\% (1-octene), indicating that this compound can be used as an effective catalyst for epoxidation. ${ }^{120}$

The photochemically reduced $\left(\lambda>320 \mathrm{~nm}\right.$, propan-2-ol as a sacrificial reagent) tungstosilicate, $\left[\mathrm{SiW}^{V} \mathrm{~W}^{\mathrm{V}}{ }_{111} \mathrm{O}_{40}\right]^{5-}$, was used to obtaine fine metal nanoparticles of $\mathrm{Ag}, \mathrm{Au}, \mathrm{Pd}$, and $\mathrm{Pt}$, by simple mixing of the corresponding metal ions with reduced polyoxometalates at room temperature. ${ }^{128}$

\section{Capped Keggin polyoxometalates}

The surface modification of a classical Keggin anion with other groups may adjust or ameliorate the physicochemical properties of the Keggin ion itself. Inorganic $\{\mathrm{VO}\}$ capped Keggin-type derivatives (FIG. 1 b) have been synthesized by hydrothermal technique. These compounds are mainly obtained as bi-capped and tetra-capped bivanadyl POMos, bi-capped 
378

379

380

381

382

383

384

385

386

387

388

389

390

391

392

393

394

395

396

397

398

399

400

401

402

403

404

405

406

407

408

409

410

411

412

413

414

bivanadyl POTs and polyoxoniobates (PONs), and bi-capped bimolybdenum and biantimony POMos do also exist. (TABLE S3, S4)

Redox-properties of bi-capped bivanadyl Mo and mixed Mo/V polyoxometalates. Highly reduced bi-capped bivanadyl mixvalence molybdenum Keggin anions $\left\{\mathrm{XMO}^{\mathrm{V} / \mathrm{NI}}{ }_{12} \mathrm{O}_{40}\left(\mathrm{~V}^{\mathrm{VV}} \mathrm{O}\right)_{2}\right\}(\mathrm{X}=\mathrm{Si}, \mathrm{P}, \mathrm{Ge}, \mathrm{As}, \mathrm{V})^{104,105,129-138}$ or molybdenum-vanadium anions $\left\{\mathrm{XMo}^{\mathrm{V} / \mathrm{VI}}{ }_{8} \mathrm{~V}^{\mathrm{IV} / \mathrm{V}}{ }_{4} \mathrm{O}_{40}\left(\mathrm{~V}^{\mathrm{IV}} \mathrm{O}\right)_{2}\right\}(\mathrm{X}=\mathrm{P}, \mathrm{V})^{103,139-147}$ were firstly presented by Hill et al. ${ }^{131}$ in 1996 and proved to be useful building blocks to construct multi-dimensional extended solid materials that show oxidative resistance and act as catalysts in homogeneous oxidation (FIG. 1 b; FIG. 3 b). 26 reduced bi-capped bivanadyl POMos and mixed POMo/Vs, which accept between two and eight electrons, were crystallized and investigated by single-crystal XRD (TABLE S3) up to now.

A number of bi-capped Keggin-type structures have been synthesized by hydrothermal reactions, sometimes supported by organic ligands (bipyridine, 1,10-phenanthroline etc) and transition metals ( $\mathrm{Co}^{11}{ }^{105} \mathrm{Cu}^{\prime}{ }^{137} \mathrm{Zn}^{\prime \prime}{ }^{134}$ etc). Under these conditions the reactions allow only little control over the stoichiometry or the degree of reduction.

Capping of the $\{\mathrm{VO}\}$ units on two opposite sides of $\alpha$-Keggin POMs results in an asymmetrical negative charge distribution and polarization of the POMo core making them attractive for asymmetric modification with transition metal cations (e.g. $\mathrm{Ni}^{11}{ }^{133} \mathrm{Cu}^{\prime}{ }^{137}{ }^{13}{ }^{11}{ }^{105}$ ). Moreover, the steric orientations of the coordination sites for the capped Keggin POMos are more flexible than those for the uncapped species.

The first reported bi-capped POMo, the $\left[\mathrm{PMo}_{6}{ }_{6} \mathrm{Mo}^{\mathrm{V} /}{ }_{6} \mathrm{O}_{40}\left(\mathrm{~V}^{\mathrm{IV}} \mathrm{O}\right)_{2}\right]^{5-}$ anion, ${ }^{131}$ can be best described as an $\alpha$-Keggin core $\left\{\mathrm{PMo}_{12} \mathrm{O}_{40}\right\}$ with $\{\mathrm{VO}\}$ units capping two opposite pits. Caps are formed through the ligation of four oxygen atoms originating from two opposite $\left\{\mathrm{Mo}_{4} \mathrm{O}_{4}\right\}$ faces to each $\{\mathrm{VO}\}$ unit in a square pyramidal manner (FIG. 3 b). DFT calculations ${ }^{132}$ confirmed Hill's suggestion that the metal centers in this reduced anion contain eight $d$ electrons: six are accommodated in three symmetry-adapted Mo orbitals, while the other two $d$ electrons are in quasi degenerate linear combinations of the $d$ vanadium orbitals.

By using the Wells-Dawson-type $\mathrm{POMo}_{6} \mathrm{P}_{2} \mathrm{Mo}_{18} \mathrm{O}_{62} \cdot \mathrm{nH}_{2} \mathrm{O}$ and $\mathrm{NH}_{4} \mathrm{VO}_{3}$ as starting material in a hydrothermal reaction it is possible to obtain another Mo-V bi-capped bivanadyl mixed Mo/V Keggin-type derivative, namely

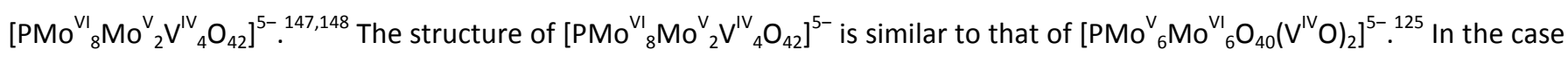
of bi-capped molybdenum-vanadium anions $\left\{\mathrm{XMo}^{\mathrm{V} / \mathrm{NI}}{ }_{8} \mathrm{~V}^{\mathrm{IV} / \mathrm{V}}{ }_{4} \mathrm{O}_{40}\left(\mathrm{~V}^{\mathrm{IV}} \mathrm{O}\right)_{2}\right\}(\mathrm{X}=\mathrm{P}, \mathrm{V}){ }^{103,139-147}$ the $\alpha$-Keggin core is based on a central $\left\{\mathrm{XO}_{4}\right\}$ tetrahedron surrounded by four corner sharing triads of $\left\{\mathrm{Mo}_{2} \mathrm{VO}_{13}\right\}$, which is composed of two $\left\{\mathrm{MoO}_{6}\right\}$ octahedra and one square $\left\{\mathrm{VO}_{5}\right\}$ pyramid (FIG. 3 b).

Generally, variable-temperature magnetic susceptibility measurements showed the presence of antiferromagnetic interactions among the reduced $\mathrm{Mo}^{\mathrm{V}}$ ions plus a paramagnetic contribution from the $\mathrm{V}^{\mathrm{IV}}$ ions in $\left\{\mathrm{XMo}{ }^{\mathrm{V} / \mathrm{VI}}{ }_{12} \mathrm{O}_{40}\left(\mathrm{~V}^{\mathrm{IV}} \mathrm{O}\right)_{2}\right\}(\mathrm{X}=\mathrm{Si}, \mathrm{P}$, $\mathrm{Ge}, \mathrm{As}) .{ }^{133,134,137,138}$ In addition, an antiferromagnetic interaction is possible between the cation (e.g. Co"I) and the $\mathrm{V}^{\mathrm{IV}}$ ions, which are directly linked through an oxygen bridge.

Studies of the electrochemical properties of compounds with $\left\{\mathrm{XMo}^{\mathrm{V} / \mathrm{NI}}{ }_{12} \mathrm{O}_{40}(\mathrm{VO})_{2}\right\}(\mathrm{X}=\mathrm{Si}, \mathrm{P}, \mathrm{Ge}, \mathrm{As})^{134,135,139}$ structure revealed similar redox behavior to the parent Keggin $\left\{\mathrm{XMo}_{12} \mathrm{O}_{40}\right\}$, that is, they undergo three two-electron reversible reductions of molybdenum. The $\mathrm{V}^{\mathrm{IV}} \mathrm{O}^{2+}$ caps have a slight effect on the electrochemical properties and no redox waves of $\mathrm{V}^{\mathrm{IV}}$ can be observed. ${ }^{134}$

Bi-capped anions $\left[\mathrm{PMo}^{\mathrm{V} / \mathrm{VI}}{ }_{12} \mathrm{O}_{40}\left(\mathrm{~V}^{\mathrm{VV}} \mathrm{O}\right)_{2}\right]^{\mathrm{n}-}$ with two localized spins have been proposed as qubits for molecular spintronics. ${ }^{35}$ Here, the molybdenum core acts as a reservoir for a variable number of delocalized electrons and exhibits weak 
magnetic coupling with the two $(\mathrm{VO})_{2}{ }^{+}$units. Through electrical manipulation of the molecular redox potential, the charge of the core can be changed, thus two-qubit gates and qubit readout can be implemented. ${ }^{35}$

The $\left[\mathrm{HPMO}{ }_{8}^{\mathrm{VI}} \mathrm{V}_{4}^{\mathrm{V}} \mathrm{O}_{40}\left(\mathrm{~V}^{\mathrm{IV}} \mathrm{O}\right)_{2}\right]^{2-}$-carbon paste electrode (CPE) exhibits bifunctional electrocatalytic activities, namely reduction of iodate $\mathrm{IO}_{3}{ }^{-}$and oxidation of ascorbic acid with electrocatalytic efficiency (CAT) of $57 \%$ and $43 \%$, respectively, which are considerably higher than the CAT values for $\mathrm{HPMO}{ }_{12}^{\mathrm{VV}} \mathrm{O}_{40}{ }^{2-}-\mathrm{CPE}(16 \%$ and $1 \%) .{ }^{139}$ Here and throughout it should be noted, that CPEs are quite unstable and some of POM electrochemical features can involve the CPE components.

Redox-properties of bi-capped bivanadyl polyoxotungstates and polyoxoniobates. The only two examples of reduced bicapped bivanadyl polyoxotungstates, $\left[\mathrm{V}^{\mathrm{IV}} \mathrm{W}_{2}^{\mathrm{V}} \mathrm{W}^{\mathrm{VI}}{ }_{10} \mathrm{O}_{40}\left(\mathrm{~V}^{\mathrm{IV}} \mathrm{O}\right)_{2}\right]^{2-149}$ and $\left[\mathrm{As}^{\mathrm{V}} \mathrm{W}^{\mathrm{V}}{ }_{4} \mathrm{~W}_{6}{ }_{6} \mathrm{~V}^{\mathrm{IV}}{ }_{4} \mathrm{O}_{42}\right]^{7-}$, ${ }^{122}$ have been reported recently (TABLE S3). Photocatalytic studies indicate that the compound $\left[\mathrm{Ni}^{\prime \prime} \mathrm{L}_{4} \mathrm{~V}^{\mathrm{IV}} \mathrm{W}^{\mathrm{VI}}{ }_{10} \mathrm{~W}_{2}{ }_{2} \mathrm{O}_{40}\left(\mathrm{~V}^{\mathrm{IV}} \mathrm{O}\right)_{2}\right] \quad(\mathrm{L}=1,4$-bis(imidazol-1ylmethyl)benzene) not only serves as an active photocatalyst for the degradation of dye molecules but also exhibits selective photocatalytic activity for the degradation of cationic dyes in aqueous solution. ${ }^{149}$ Furthermore, two bi-capped bivanadyl structures are known for polyoxoniobate: fully-oxidized $\left[\mathrm{V}^{\mathrm{V}} \mathrm{Nb}^{\mathrm{V}}{ }_{12} \mathrm{O}_{40}\left(\mathrm{~V}^{\mathrm{V}} \mathrm{O}\right)_{2}\right]^{9-}$ and the three-electron reduced $\left[\mathrm{V}^{\mathrm{IV}} \mathrm{Nb}_{12}^{\mathrm{V}} \mathrm{O}_{40}\left(\mathrm{~V}^{\mathrm{IV}} \mathrm{O}\right)_{2}\right]^{11-}{ }^{150,151}$ They were synthesized under similar hydrothermal conditions but for the synthesis of the reduced anion ethylenediamine was presented in the reaction mixture.

Redox-properties of bi-capped bimolybdenum and biantimony polyoxomolybdates. The formation of molybdenum-capped anions is also possible if no vanadium compound is present in the reaction mixture. Six reduced bimolybdenum and biantimony POMos, which accept between four and eight electrons, were crystallized and investigated by single-crystal XRD (TABLE S3).

Polyoxoanion $\left[\mathrm{SiMo}_{4}{ }_{4} \mathrm{Mo}^{\mathrm{VI}}{ }_{10} \mathrm{O}_{44}\right]^{4-152}$ which was synthesized by reaction of the oxothio precursor $\left[\mathrm{Mo}_{12} \mathrm{~S}_{12} \mathrm{O}_{12}(\mathrm{OH})_{12}\left(\mathrm{H}_{2} \mathrm{O}\right)_{6}\right]^{4-}$ with hydrochloric acid, silicate anions, and tetramethylammonium hydroxide under hydrothermal conditions, is capped by $\left\{\mathrm{Mo}^{\mathrm{VI}} \mathrm{O}_{2}\right\}$ subunits sharing two $\mathrm{O}$ atoms to form a dimer. At high temperature and low $\mathrm{pH}, \mathrm{a}$ hypothetical five-electron reduced-Keggin structure with two $\left\{\mathrm{Mo}^{\mathrm{V}} \mathrm{O}_{2}\right\}$ capping units is obtained. This electron-rich species dimerizes to form $\left[\mathrm{Si}_{2} \mathrm{Mo}_{14}^{\mathrm{V}}{ }_{14} \mathrm{Mo}^{\mathrm{VI}}{ }_{14} \mathrm{O}_{84}\left(\mathrm{H}_{2} \mathrm{O}\right)_{2}\right]^{6-}$ (FIG. $\left.3 \mathrm{c}\right) .{ }^{152}$

The $\left[\mathrm{AlMo}_{4}{ }_{4} \mathrm{MoO}_{8}{ }_{8} \mathrm{O}_{40}\left(\mathrm{Mo}^{\mathrm{VI}} \mathrm{O}_{2}\right)\right]^{5-153}$ and $\left[\left(\mathrm{As}^{\mathrm{V}} \mathrm{O}_{4}\right) \mathrm{Mo}^{\mathrm{VV}}{ }_{6} \mathrm{Mo}_{6}{ }_{6} \mathrm{O}_{35}\left(\mathrm{Mo}^{\mathrm{V}} \mathrm{O}_{2}\right]^{-154}\right.$ anions also demonstrate bi-capped Keggin structures. The attachment of capping units to the Keggin-type polyanion can be described as a Lewis-type interaction between the four-electron-reduced $\left\{\mathrm{XMo}_{4}{ }_{4} \mathrm{Mo}^{\mathrm{VV}}{ }_{8} \mathrm{O}_{40}\right\}$ species, acting as a base, and the $\left\{\mathrm{Mo}^{\mathrm{VI}} \mathrm{O}_{2}\right\}$ as Lewis acid, which exhibit a structure stabilizing effect.

The catalytic property of $\left[\left(\mathrm{As}^{\mathrm{V}} \mathrm{O}_{4}\right) \mathrm{Mo}_{6}{ }_{6}^{\mathrm{V}} \mathrm{Mo}_{6}{ }_{6} \mathrm{O}_{35}\left(\mathrm{Mo}^{\mathrm{V}} \mathrm{O}\right)_{2}\right]^{-153}$ has been explored showing that it is able to convert styrene to benzaldehyde (85.2\%). In the same time the catalytic properties of $\left[\mathrm{AlMo}_{4}{ }_{4} \mathrm{Mo}^{\mathrm{VI}}{ }_{8} \mathrm{O}_{40}\left(\mathrm{Mo}^{\mathrm{VI}} \mathrm{O}_{2}\right)\right]^{5-}{ }^{153}$ were evaluated in the oxidation of cyclohexanol to cyclohexanone. A conversion rate of $26.7 \%$ with a high selectivity of $98.5 \%$ for the conversion to cyclohexanone was reported. It has to be noted that a blank reaction without POMo gives only $4.2 \%$ of conversion.

POMs containing antimony oxide units often play an important role in heterogeneous oxidation catalysis. Moreover, antimony cations also have a stabilizing effect on polyoxometalates at high temperatures. ${ }^{154}$ The bi-capped antimony $\alpha$ Keggin anion $\left[\mathrm{PMO}_{5}{ }_{5} \mathrm{Mo}^{\mathrm{VI}}{ }_{7} \mathrm{Sb}_{2}{ }_{2} \mathrm{O}_{40}\right]^{2-}$ can be synthesized either under hydrothermal conditions in the system of $\mathrm{Sb}_{2} \mathrm{O}_{3}-\left(\mathrm{NH}_{4}\right)_{6} \mathrm{Mo}_{7} \mathrm{O}_{24}-\mathrm{H}_{3} \mathrm{PO}_{4}-$ en $-\mathrm{H}_{2} \mathrm{O}{ }^{155,156}$ or by reduction of $\left(\mathrm{Bu}_{4} \mathrm{~N}\right)_{3}\left[\mathrm{PMo}_{12} \mathrm{O}_{40}\right]$ with six mole-equivalents of $\mathrm{Na} / \mathrm{Hg}$ 
451 amalgam in the presence of two mole-equivalents of $\mathrm{SbCl}_{3}$ following to the scheme: ${ }^{104}$ $452 \quad\left[\mathrm{PMo}_{12} \mathrm{O}_{40}\right]^{3-}+2 \mathrm{SbCl}_{3}+6 \mathrm{e} \rightarrow\left[\mathrm{PMo}_{12} \mathrm{O}_{40} \mathrm{Sb}_{2}\right]^{3-}+6 \mathrm{Cl}^{-}$.

453 Redox-properties of tetra-capped pseudo-Keggin polyoxoanions. In contrast to bi-capped Keggin systems tetra-capped 454 structures of electron-rich POMs are known only for mixed Mo/V systems with the general formula $\left\{\mathrm{XMo}_{8}^{\mathrm{V} / \mathrm{VI}} \mathrm{V}_{8}^{\mathrm{V} / \mathrm{VV}}\right\}, \mathrm{X}=\mathrm{P}, \mathrm{V}$, 455 As (FIG. 1 b; FIG. 4 d). ${ }^{103,122,157-165} 19$ reduced tetra-capped pseudo Keggin polyoxoanions, which accept between eight and 456 thirteen electron, were crystallized and investigated by single-crystal XRD so far (TABLE S4).

All tetra-capped compounds are synthesized in a similar fashion. When applying hydrothermal synthesis, the 458 heteropolyacids $\mathrm{H}_{3} \mathrm{XMo}_{12} \mathrm{O}_{40}(\mathrm{X}=\mathrm{P}, \mathrm{As})$ and $\mathrm{NH}_{4} \mathrm{~V}^{\mathrm{V}} \mathrm{O}_{3}$ are often used as the starting material. Wang and coworkers pointed out 459 that the use of $\mathrm{NH}_{4} \mathrm{VO}_{3}$ as precursor in the transformation reaction of the Keggin into the pseudo-Keggin structure may 460 increase the negative charge density on the external oxygen atoms leading to a more reactive POM anion. ${ }^{159}$ Using $461 \quad \mathrm{H}_{2} \mathrm{C}_{2} \mathrm{O}_{4} \cdot 2 \mathrm{H}_{2} \mathrm{O}$ during the synthesis not only decreases the $\mathrm{pH}$ of the reaction system but also can act as a reducing agent. ${ }^{157}$ $462 \quad\left[\left(\mathrm{XO}_{4}\right) \mathrm{Mo}^{\mathrm{V} / \mathrm{VI}}{ }_{8} \mathrm{~V}_{8}^{\mathrm{IV}}{ }_{8} \mathrm{O}_{40}\right]^{\mathrm{n}-}$ is structurally based on the $\alpha$-Keggin $\left\{\left(\mathrm{PO}_{4}\right) \mathrm{Mo}^{\mathrm{V} / \mathrm{VI}}{ }_{8} \mathrm{~V}^{\mathrm{IV}}{ }_{4} \mathrm{O}_{36}\right\}$ (FIG. $\left.1 \mathrm{~b}\right)$ archetype containing four 463 additional five-coordinated terminal $\mathrm{V}^{\mathrm{IV}} \mathrm{O}^{2+}$ units. One distorted and disordered $\mathrm{XO}_{4}{ }^{3-}(\mathrm{X}=\mathrm{P}, \mathrm{V}, \mathrm{As})$ tetrahedron lies inside the 464 host cavity. The Mo ions are all six-coordinated resulting in an octahedral geometry. Each vanadium ion possesses a distorted $465\left\{\mathrm{VO}_{5}\right\}$ square pyramidal geometry with eight vanadium ions forming the central belt by sharing edges of $\left\{\mathrm{VO}_{5}\right\} \mathrm{square}$ 466 pyramids. There are two $\left\{\mathrm{Mo}_{4} \mathrm{O}_{18}\right\}$ rings by common edges above and below the $\mathrm{V}_{8}$ belt. The assignments of the oxidation 467 state for the molybdenum and vanadium ions are consistent with their coordination geometry and confirmed by bond 468 valence sum calculations. In most of the cases the transition metal ( $\mathrm{Co}$ ", $\mathrm{Ni}$ " or $\mathrm{Cu}^{\prime \prime}$ ) complexes do covalently link to the anion 469 via terminal capping $V^{\mathrm{IV}}=0$ groups (FIG. $3 \mathrm{~d}$ ).

$470 \quad$ An Ab Initio and DFT study of $\left[\mathrm{PMo}_{2}{ }_{2} \mathrm{Mo}_{6}{ }_{6} \mathrm{~V}_{4}{ }_{4} \mathrm{O}_{40}\left(\mathrm{~V}^{\mathrm{IV}} \mathrm{O}\right)_{4}\right]^{5-}$ shows that six of ten accepted electrons are delocalized 471 over the $\mathrm{V}_{8}$-ring, whereas the remaining electrons are deloclaized over the Mo centers. ${ }^{166}$ As with bi-capped anions, variable472 temperature magnetic susceptibility measurements were performed and show the presence of antiferromagnetic 473 interactions betweem the reduced $\mathrm{Mo}(\mathrm{V})$ and $\mathrm{V}(\mathrm{IV})$ atoms. ${ }^{157-160}$

\section{Wells-Dawson-type polyoxometalates}

So far eight reduced POMos, two reduced POTs and three mixed-metal (Mo/W and V/Mo) POMs of Wells-Dawson structure, which accept between one and up to five electrons, were crystallized and investigated by single-crystal XRD so far 477 (Table S5).

478 Polyoxomolybdates exhibiting the Wells-Dawson structure. The one- and two electron reduction of $\alpha-\left[\mathrm{P}_{2} \mathrm{Mo}^{\mathrm{VI}}{ }_{18} \mathrm{O}_{62}\right]^{6-}$ in 479 acetonitrile leads to $\alpha-\left[\mathrm{P}_{2} \mathrm{Mo}{ }^{\mathrm{V}} \mathrm{Mo}^{\mathrm{VI}}{ }_{17} \mathrm{O}_{62}\right]^{7-}$ and $\alpha-\left[\mathrm{P}_{2} \mathrm{Mo}^{\mathrm{V}}{ }_{2} \mathrm{Mo}^{\mathrm{VI}}{ }_{17} \mathrm{O}_{62}\right]^{8-}$, which were confirmed by EPR and ${ }^{31} \mathrm{P}$ NMR studies. ${ }^{167}$ 480 The magnitudes of the EPR $g$ values suggest that the odd electron is either delocalized or is rapidly hopping between a mirror481 plane-related pair of equatorial $\mathrm{Mo}$ atoms. ${ }^{167}$ Electrolytic reduction of $\left[\left(\mathrm{P}_{2} \mathrm{O}_{7}\right) \mathrm{Mo}^{\mathrm{V}}{ }_{18} \mathrm{O}_{54}\right]^{4-}$ at $0.11 \mathrm{~V}$ in acetonitrile solution 482 yielded the green one-electron reduced species $\left[\left(\mathrm{P}_{2} \mathrm{O}_{7}\right) \mathrm{Mo}^{\mathrm{V}} \mathrm{Mo}^{\mathrm{V}}{ }_{17} \mathrm{O}_{54}\right]^{5-}$ and the blue two-electron-reduced species $483\left[\left(\mathrm{P}_{2} \mathrm{O}_{7}\right) \mathrm{Mo}_{2}{ }_{2} \mathrm{Mo}^{\mathrm{VI}}{ }_{16} \mathrm{O}_{54}\right]^{6-}$, of which formation was confirmed by ${ }^{31} \mathrm{P}$ NMR and EPR studies. ${ }^{168}$ Four compounds contain two or 484 three electron reduced Wells-Dawson anions $\left\{\mathrm{As}_{2} \mathrm{Mo}_{18} \mathrm{O}_{62}\right\}$, which are capped by a certain number of $\mathrm{Cu}^{\prime \prime}$ or $\mathrm{As}$ "I' species on 485 different coordination positions. These compounds were hydrothermaly synthesized by altering of the $\mathrm{pH}$ and the organic 486 ligand within the reaction system. ${ }^{169}$ 
Reduction by two or more electrons produces highly basic forms that have been isolated as protonated polyoxometalate salts. ${ }^{170}$ The dependence of the EPR line width on temperature for $\left[{ }^{n} \mathrm{Bu}_{4} \mathrm{~N}_{5}\left[\mathrm{H}_{3} \mathrm{~S}_{2} \mathrm{Mo}^{\mathrm{V}} \mathrm{Mo}^{\mathrm{VI}}{ }_{17} \mathrm{O}_{62}\right]\right.$ is consistent with the intermolecular thermal delocalization of the odd electron over the entire molecular framework in the temperature range from 77 to $253 \mathrm{~K}^{171}$ By reaction of $\left[{ }^{\mathrm{n}} \mathrm{Bu}_{4} \mathrm{~N}\right]_{4}\left[\mathrm{H}_{3} \mathrm{~S}_{2} \mathrm{Mo}^{\mathrm{VI}}{ }_{18} \mathrm{O}_{62}\right]$ with triphenylphosphine in acetonitrile the four-electron reduced $\alpha$-Wells-Dawson compound $\left[{ }^{n} \mathrm{Bu}_{4} \mathrm{~N}_{5}\left[\mathrm{H}_{3} \mathrm{~S}_{2} \mathrm{Mo}^{\mathrm{V}}{ }_{4} \mathrm{Mo}^{\mathrm{vv}}{ }_{12} \mathrm{O}_{62}\right] \cdot 4 \mathrm{MeCN}\right.$ was prepared. ${ }^{172}$ The most significant structural alterations, compared to the parent structure, are an increase in the Mo-Mo distances between corner-sharing $\mathrm{MoO}_{6}$ units in the equatorial belt by $0.066 \AA$ and a decrease in the Mo-O-Mo bond length connecting the two halves of the anion. $\left(\mathrm{C}_{16} \mathrm{H}_{18} \mathrm{~N}_{3} \mathrm{~S}\right)_{5}\left[\mathrm{~S}_{2} \mathrm{Mo}^{\mathrm{V}} \mathrm{Mo}_{17}{ }_{17} \mathrm{O}_{62}\right] \cdot \mathrm{CH}_{3} \mathrm{CN}$ was used to fabricate a modified carbon paste electrode (CPE) which exhibits five redox peaks in the potential range from $-300 \mathrm{mV}$ to $700 \mathrm{mV}$ exhibiting more positive first redox potentials than the $\left[\mathrm{P}_{2} \mathrm{Mo}^{\mathrm{VI}}{ }_{18} \mathrm{O}_{62}\right]^{6-}$ ion and in addition higher stability and electrocatalytic activity towards the reduction of nitrite, chlorate, bromate and hydrogen peroxide in acidic ( $\left.1 \mathrm{M} \mathrm{H}_{2} \mathrm{SO}_{4}\right)$ aqueous solution. ${ }^{34}$

$\alpha-\left[\left(\mathrm{SO}_{3}\right)_{2} \mathrm{Mo}_{2}{ }_{2} \mathrm{Mo}^{\mathrm{VI}}{ }_{16} \mathrm{O}_{54}\right]^{6-}$, which incorporates the pyramidal sulfite anion, was synthesized in the presence of an excess of triethanolamine (TEA) at pH 4.0 with $\mathrm{Na}_{2} \mathrm{~S}_{2} \mathrm{O}_{4}$ not only acting as reducing agentbut also as the source for the incorporated of $\mathrm{SO}_{3}{ }^{2-} \cdot{ }^{173}$ The electrochemistry of these two-electron rich anion has been investigated in aqueous media using cyclic and rotated disk voltammetry at glassy carbon electrodes and bulk electrolysis with a focus on the $\mathrm{pH}$-dependence for the oxidation to $\alpha-\left[\mathrm{Mo}_{18}^{\mathrm{VI}} \mathrm{O}_{54}\left(\mathrm{SO}_{3}\right)_{2}\right]^{4-}{ }^{174}$ In buffered media at $\mathrm{pH} \geq 4$, the cyclic voltammetric response for $\alpha$ $\left[\left(\mathrm{SO}_{3}\right)_{2} \mathrm{Mo}_{2}{ }_{2} \mathrm{Mo}_{16}{ }_{16} \mathrm{O}_{54}\right]^{6-}$ reveals two partially resolved one-electron oxidation processes corresponding to the sequential generation of $\alpha-\left[\left(\mathrm{SO}_{3}\right)_{2} \mathrm{Mo}^{\mathrm{V}} \mathrm{Mo}^{\mathrm{VI}}{ }_{17} \mathrm{O}_{54}\right]^{5-}$ and $\alpha-\left[\left(\mathrm{SO}_{3}\right)_{2} \mathrm{Mo}_{18}{ }_{18} \mathrm{O}_{54}\right]^{4-} \cdot{ }^{174} \alpha-\left[\left(\mathrm{SO}_{3}\right)_{2} \mathrm{Mo}_{2}{ }_{2} \mathrm{Mo}^{\mathrm{VI}}{ }_{16} \mathrm{O}_{54}\right]^{6-}$ was obtained during simple one-pot reaction because $\alpha-\left[\mathrm{Mo}_{18}^{\mathrm{VI}} \mathrm{O}_{54}\left(\mathrm{SO}_{3}\right)_{2}\right]^{4-}$ is slightly easier to reduce than the $\beta$-form. Furthermore, on a much longer bulk electrolysis timescale, $\beta \rightarrow \alpha$ isomerisation occurs showing that the reduced forms of the $\alpha$-isomer are thermodynamically favoured over the $\beta$ forms, which was shown by Cronin and co-workers. ${ }^{175}$ In aprotic acetonitrile $\beta$ $\left[\mathrm{Mo}_{18}{ }_{18} \mathrm{O}_{54}\left(\mathrm{SO}_{3}\right)_{2}\right]^{4-}$ is retained on the voltammetric timescale upon one- and two-electron reduction. $\alpha-\left[\left(\mathrm{SO}_{3}\right)_{2} \mathrm{Mo}^{\mathrm{VI}}{ }_{18} \mathrm{O}_{54}\right]^{4-}$ undergoes reduction slightly easier than the $\beta$ form.

\section{Box 2 |Wells-Dawson structure}

In 1892, Kehrmann described the synthesis of a Wells-Dawson-type phosphotungstate for the first time. ${ }^{261}$ However, Dawson published the first crystallographic study of this structure 60 years later. ${ }^{262}$ The general formula of the WellsDawson anion is $\left[\left(\mathrm{XO}_{4}\right)_{2} \mathrm{M}_{18} \mathrm{O}_{54}\right]^{\mathrm{n}-} ; \mathrm{M}=\mathrm{Mo}, \mathrm{W}$ and $\mathrm{X}=$ main-group element. The classical Wells-Dawson structure incorporates two tetrahedral anions such as $\mathrm{PO}_{4}{ }^{3-},{ }^{262} \mathrm{AsO}_{4}{ }^{3-},{ }^{263} \mathrm{SO}_{4}{ }^{2-170}$ or $\mathrm{ClO}_{4}{ }^{-178}$. There are only a few examples of $\left\{\mathrm{M}_{18}\right\}$ Wells-Dawson-like clusters that host non-tetrahedral anions, for example, a single pyramidal anion $\mathrm{BiO}_{3}{ }^{3-}{ }^{264}, \mathrm{AsO}_{3}{ }^{3-}{ }^{265}$ or $\mathrm{SO}_{3}{ }^{2-173}$ in each $\left\{\mathrm{M}_{9}\right\}$ unit, presumably due to size restrictions. A ditetrahedral anion $-\mathrm{P}_{2} \mathrm{O}_{7}{ }^{4-}{ }^{168}$ (two tetrahedral sharing one corner) was also observed in the centre of the structure. The structure, known as $\alpha$-Wells-Dawson isomer, possesses two identical "half units" of the central atom surrounded by nine octahedral units $\mathrm{XM}_{9} \mathrm{O}_{31}$ linked through oxygen atoms. The isomeric $\beta$-Wells-Dawson structure originates from the rotation of one half unit by $\pi / 3$ around the axis connecting both heteroatoms. Similarly to many heteropolyanions, the Wells-Dawson structure can be chemically manipulated to generate lacunary units by removing up to six $\mathrm{MO}_{6}$ octahedra, which gives $\mathrm{X}_{2} \mathrm{M}_{12}$ anion. The redox properties of Wells-Dawson 
polyoxometalates in aqueous media have received limited attention because of their low solubility and their instability under basic conditions. $^{266-268}$

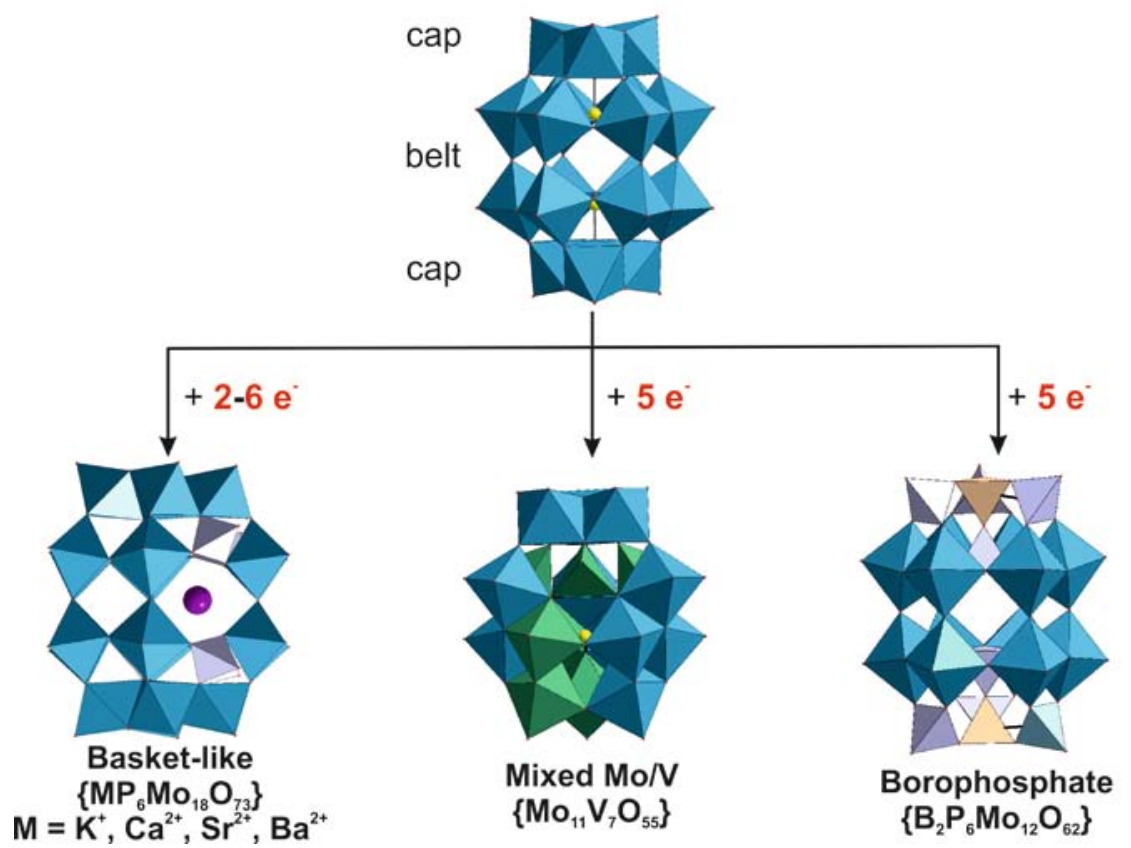

Color code: $\mathrm{MoO}_{6}$, blue octahedral; $\mathrm{PO}_{4}$, lilac terahedra; $\mathrm{VO}_{\mathrm{n}}$, green polyhedra; $\mathrm{S}$, yellow sphere.

511

512

513

514

515

516

517

518

519

520

521

522

523

524

525

526

527

528

529

530

Polyoxotungstates exhibiting the Wells-Dawson structure. $\alpha-\left[\left(\mathrm{SO}_{3}\right)_{2} \mathrm{~W}^{\mathrm{V}} \mathrm{W}^{\mathrm{VI}}{ }_{17} \mathrm{O}_{54}\right]^{5-}$ was obtained as $\operatorname{Pr}_{4} \mathrm{~N}^{+}(\operatorname{Pr}=\operatorname{propyl})$ salt by reducing the so-called "Trojan Horse" $\left[\left(\mathrm{SO}_{3}\right)_{2} \mathrm{~W}_{18}^{\mathrm{Vl}} \mathrm{O}_{56}\left(\mathrm{H}_{2} \mathrm{O}\right)_{2}\right]^{8-}$ cluster ${ }^{176}$ via a template orientation transformation. Cyclic voltammetry of $\alpha-\left[\left(\mathrm{SO}_{3}\right)_{2} \mathrm{~W}^{\mathrm{VI}}{ }_{18} \mathrm{O}_{54}\right]^{4-}$ and $\alpha-\left[\left(\mathrm{SO}_{3}\right)_{2} \mathrm{~W}^{\mathrm{V}} \mathrm{W}^{\mathrm{VI}}{ }_{17} \mathrm{O}_{54}\right]^{5-}$ in $\mathrm{CH}_{3} \mathrm{CN}$ produces evidence for an extensive series of reversible one-electron redox processes that are associated with the tungsten-oxo framework of the POT cluster. ${ }^{177}$ The encapsulated sulfite anions in the "Trojan Horse" $\left[\mathrm{W}^{\mathrm{VI}}{ }_{18} \mathrm{O}_{56}\left(\mathrm{SO}_{3}\right)_{2}\left(\mathrm{H}_{2} \mathrm{O}\right)_{2}\right]^{8-}$ cluster ${ }^{176}$ act as embedded reducing agents and are oxidized to sulfate when heated to over $400{ }^{\circ} \mathrm{C}$ according to the following reaction scheme: $\left[\left(\mathrm{S}^{\mathrm{IV}} \mathrm{O}_{3}\right)_{2} \mathrm{~W}^{\mathrm{VI}}{ }_{18} \mathrm{O}_{56}\right.$ $\left.\left(\mathrm{H}_{2} \mathrm{O}\right)_{2}\right]^{8-} \rightarrow\left[\left(\mathrm{S}^{\mathrm{VI}} \mathrm{O}_{4}\right)_{2} \mathrm{~W}_{4}{ }_{4} \mathrm{~W}^{\mathrm{VI}}{ }_{14} \mathrm{O}_{54}\left(\mathrm{H}_{2} \mathrm{O}\right)_{2}\right]^{8-}+2 \mathrm{H}_{2} \mathrm{O}$.

The only example of a Wells-Dawson-type anion with $\mathrm{ClO}_{4}{ }^{2-}$ as heteroatom was observed in $\left[{ }^{n} \mathrm{Bu}_{4} \mathrm{~N}_{3}\left[\mathrm{Cl}_{2} \mathrm{~W}^{\mathrm{V}} \mathrm{W}^{\mathrm{VI}}{ }_{17} \mathrm{O}_{62}\right]\right.$, which was obtained under UV irradiation from monomeric $\mathrm{WO}_{4}{ }^{2-}{ }^{178}$ The powder EPR spectrum of reduced tungstoperchlorate indicates the presence of $W^{V}$ and suggests that the unpaired electron may be delocalized over the $\mathrm{W}$ atoms in the anion network due to thermally activated electron hopping.

The potential photocatalyst for oxidative decomposition of methylene blue dye contains $\left[\mathrm{As}_{2} \mathrm{~W}^{\mathrm{V}}{ }_{2} \mathrm{~W}^{\mathrm{Vl}}{ }_{16} \mathrm{O}_{62}\right]^{8-}$, which is connected to eight copper ions and synthesized under hydrothermal conditions. ${ }^{179}$

Addenda priority for electron acceptance in mixed-metal Wells-Dawson polyoxometalates. Baker and co-workers investigated mixed Mo/W electron-rich anions and the derivatives of parent $\left[\mathrm{P}_{2} \mathrm{Mo}_{n} \mathrm{~W}_{18-n} \mathrm{O}_{62}\right]^{6-}(n=1-6)$ in aqueous solution using ${ }^{31} \mathrm{P}$ and ${ }^{183} \mathrm{~W}$ NMR as well as EPR in the 1980s. ${ }^{180-183}$ In 1983, Pope reported the synthesis of Wells-Dawson lacunary polyoxotungstates and vanadyl sulfate one-electron reduced anions $\left[\mathrm{P}_{2} \mathrm{~V}^{\mathrm{IV}} \mathrm{V}_{\mathrm{n}}{ }_{\mathrm{V}} \mathrm{W}_{18-\mathrm{n}} \mathrm{O}_{62}\right]^{(8+n)-}(\mathrm{n}=1,2) .{ }^{185}$ The electrochemisrtry of mono-substituted $V^{\mathrm{IV}}$ Wells-Dawson anions $\mathrm{V}\left\{\mathrm{X}_{\mathrm{k}} \mathrm{V}^{\mathrm{IV}} \mathrm{Mo}^{\mathrm{VI}}{ }_{\mathrm{n}} \mathrm{W}^{\mathrm{VI}}{ }_{17-\mathrm{n}} \mathrm{O}_{62}\right\}\left(\mathrm{X}=\mathrm{P}, \mathrm{As} ; \mathrm{k}=1,^{185} 2 ;^{187-189} ; \mathrm{n}=0,{ }^{187-189} 2^{186}\right)$ were investigated by Nadjo et al. These anions are efficient as electrocatalysts for the reduction of $\mathrm{NO}_{2}{ }^{-}$, oxidation of $\mathrm{L}_{-} \mathrm{cysteine}$ and 
531 as stabilizing agents for the preparation of $\mathrm{Pd}^{0}$ nanoparticles. ${ }^{187-189}$ However, so far no single crystal structure of this kind of 532 Wells-Dawson anion is reported.

Cronin and co-workers recently reported a new structural type that is related to the Wells-Dawson archetype in terms of the cage geometry but with seven of the metal centres having been changed to hetero-metals like in the case of $\left(\mathrm{NH}_{4}\right)_{7}\left[\left(\mathrm{SO}_{3}\right) \mathrm{Mo}^{\mathrm{VV}}{ }_{11} \mathrm{~V}_{5}^{\mathrm{V}} \mathrm{V}^{\mathrm{IV}}{ }_{2} \mathrm{O}_{52}\right] \cdot 12 \mathrm{H}_{2} \mathrm{O}$, where $7 \mathrm{Mo}$ atoms were changed to $\mathrm{V}^{\mathrm{IV} / \mathrm{V}}$. ${ }^{190}$ The $\mathrm{V}^{\mathrm{V}}$ is partially reduced to $\mathrm{V}^{\mathrm{IV}}$ by sulphite, which also acts as a heteroanion. The distorted egg-shaped capsule of the molybdovanadate-sulfite anion is built up of two different hemispheres. In the upper hemisphere, three edge-sharing $\mathrm{MoO}_{6}$ octahedra form the cap, which is connected to the belt via vertexes of alternating $\mathrm{V}^{\mathrm{V}} \mathrm{O}_{4}$ tetrahedra and $\mathrm{MoO}_{6}$ octahedra. The $\left\{\mathrm{M}_{6}\right\}$ belt at the bottom hemisphere is made of three sets of edge-sharing $\mathrm{MoO}_{6} / \mathrm{VO}_{6}$ octahedra interconnected within the framework to give three Mo-O- $\mathrm{V}$ moieties arranged in a ring-like structure. Finally, the $\left\{M_{3}\right\}$ cap at the bottom of the cluster contains two Mo and one $V$ position, respectively (BOX 2).

Reduced Basket-like polyoxomolybdates. As a unique class of unclassical POM, the basket-like archetype $\left\{\mathrm{M} \subset \mathrm{P}_{6} \mathrm{Mo}^{\mathrm{V} /{ }_{18}}{ }_{18} \mathrm{O}_{73}\right\}(\mathrm{M}=$ alkali metal, $\subset$ - covalently incorporated) represents mixed valence molybdates, which are obtained by two or more electron reductions from the corresponding $\mathrm{Mo}^{\mathrm{V}}$ of orthomolybdate $\mathrm{MoO}_{4}{ }^{2-}{ }^{191-196}$ or heptamolybdate $\mathrm{Mo}_{7} \mathrm{O}_{24}{ }^{6--197-201}$ (BOX 2). So far 31 reduced Basket-like polyoxoanions, which accept between two and six electrons, were crystallized and investigated by single-crystal XRD up to date (TABLE S6).

All basket-like POMos were obtained by hydrothermal synthesis using potassium ${ }^{191,192}$ or alkaline earth metals ${ }^{-193}{ }_{-}{ }^{201}$ $(\mathrm{Ca}, \mathrm{Sr}, \mathrm{Ba})$ as template agents to stabilize and induce polyanions formation. The organic ligands play an important role as reducing agents to reduce the $\mathrm{Mo}^{\mathrm{VI}}$ to $\mathrm{Mo}^{\mathrm{V}}$ centers in one pot reactions including $\{\mathrm{Mo}\}\left(\mathrm{MoO}_{3} / \mathrm{Mo} \mathrm{Na}_{2} \mathrm{MoO}_{4}\right.$ or $\left.\left(\mathrm{NH}_{4}\right)_{6} \mathrm{Mo}_{7} \mathrm{O}_{24}\right), \mathrm{H}_{3} \mathrm{PO}_{4}, \mathrm{MCl}_{2}(\mathrm{M}=\mathrm{Ca}, \mathrm{Sr}, \mathrm{Ba})$ or $\mathrm{KH}_{2} \mathrm{PO}_{4}$ and $\mathrm{H}_{2} \mathrm{O}$ leading to different dimensions or packing arrangements in the final hybrid materials. ${ }^{196,198-201}$

The basket-like polyoxoanion consists of two parts: the "handle" $\left\{\mathrm{P}_{4} \mathrm{Mo}_{4}\right\}$ unit and the "basket body" $\left\{\mathrm{P}_{2} \mathrm{Mo}_{14}\right\}$ segment (BOX 2). The lower $\left\{\mathrm{P}_{2} \mathrm{Mo}_{14} \mathrm{O}_{46}\right\}$ part is a tetravacant lacunary derivative of the Wells-Dawson anion $\left[\mathrm{P}_{2} \mathrm{Mo}_{18} \mathrm{O}_{62}\right]^{6-}$ formed by removal of four "belt" Mo octahedra, in which each of the fourteen Mo atoms has only one terminal, double-bonded oxygen atom and thus meets the criteria for receiving "blue" electrons. ${ }^{14}$ The upper part $\left\{\mathrm{P}_{2} \mathrm{Mo}_{4} \mathrm{O}_{27}\right\}$ is the handle of the basket formed by four $\mathrm{MoO}_{6}$ octahedra and four $\mathrm{PO}_{4}$ tetrahedra, in which each of the four Mo atoms has two terminal, doublebonded oxygen atoms. The $\left\{\mathrm{P}_{4} \mathrm{Mo}_{4}\right\}$ and the "basket body" $\left\{\mathrm{P}_{2} \mathrm{Mo}_{14}\right\}$ moieties are connected together through edge- and corner-sharing modes. The entire basket-shaped cluster possesses $C_{2 v}$ symmetry. The Mo-O bonds between $\left\{\mathrm{P}_{4} \mathrm{Mo}_{4}\right\}$ and $\left\{\mathrm{P}_{2} \mathrm{Mo}_{14}\right\}$ have longer distances and smaller bond orders in comparison to classical Wells-Dawson anion. As a result, the negative void formed by nine oxygen atoms of the two parts is large and can accommodate either alkali or alkaline earth metals.

Another example of Wells-Dawson derivative encapsulating alkali metal $\left[\mathrm{Na}\left(\mathrm{SO}_{3}\right)_{2}\left(\mathrm{PhPO}_{3}\right)_{4} \mathrm{Mo}_{4}{ }_{4} \mathrm{Mo}^{\mathrm{VI}}{ }_{14} \mathrm{O}_{49}\right]^{5-}$ was synthesized from $\mathrm{Na}_{2} \mathrm{MoO}_{4}, \quad \mathrm{Na}_{2} \mathrm{~S}_{2} \mathrm{O}_{4}$ and phenylphosphonic acid. ${ }^{202}$ Electrochemical investigations of $\left[\mathrm{Na}\left(\mathrm{SO}_{3}\right)_{2}\left(\mathrm{PhPO}_{3}\right)_{4} \mathrm{Mo}_{4}{ }_{4} \mathrm{Mo} \mathrm{V}_{14} \mathrm{O}_{49}\right]^{5-}$ showed three redox couples, in which the electrons were mainly delocalized over eight Mo sites. ${ }^{203}$ 
$568\left[\mathrm{Sr} \subset \mathrm{P}_{6}{ }_{6} \mathrm{Mo}^{\mathrm{V} /{ }_{18}}{ }_{18} \mathrm{O}_{73}\right]^{\mathrm{n}-}$ it has been noted that catalytic activities were enhanced with increasing extent of the anion 569 reduction. ${ }^{194,199}$ The basket-like POMos demonstrated superiority over other POM archetypes as catalysts in 570 photodegradation reaction due to their special structure, which makes electrons and holes migrate rapidly to the surface of 571 the basket cage, thus improving the photocatalytic activities significantly. ${ }^{200}$

572 Five-electron reduced Wells-Dawson-like borophosphate polyoxomolybdates. In 2002, Sevov and co-wokers reported 573 synthesis and structure of a new type of reduced borophosphate POMos. (TABLE S6). ${ }^{204}$ The polyanion $\left[\mathrm{B}_{2} \mathrm{P}_{8} \mathrm{Mo}_{12} \mathrm{O}_{59}(\mathrm{OH})_{3}\right]^{8-}$ is 574 structurally very closely related to that of the $\alpha$-Wells-Dawson anion $\left[\mathrm{P}_{2} \mathrm{Mo}_{18} \mathrm{O}_{62}\right]^{6-}$ and consist of two crystallographically 575 equivalent hemispheres of $\left[\mathrm{BP}_{4} \mathrm{Mo}_{6} \mathrm{O}_{31} \mathrm{H}_{1.5}\right]^{4-}$ that are linked together by six shared oxygen atoms (BOX 2).

There are two phosphate groups inside the cluster, which are situated near the centres of the molybdenum belts. The other six phosphate groups are part of the POM cage (addenda) sharing two vertexes with two edge-sharing molybdenum octahedra and one vertex with a borate tetrahedra. The two borate groups of the anion (one in each hemisphere) share all corners with three outer and one inner phosphate groups. The magnetic measurements indicate only one unpaired electron, so the five electrons from these atoms are delocalized over the cluster and four of them are paired. The substitution of the six terminal oxygen and hydroxyl groups of the outer phosphates in $\left[\mathrm{B}_{2} \mathrm{P}_{8} \mathrm{Mo}_{12} \mathrm{O}_{59}(\mathrm{OH})_{3}\right]^{8-}{ }^{204}$ with phenyl groups leads to $\left[\left(\mathrm{BPO}_{4}\right)_{2}\left(\mathrm{O}_{3} \mathrm{P}-\mathrm{Ph}\right)_{6} \mathrm{Mo}_{5}^{\mathrm{V}} \mathrm{Mo}^{\mathrm{VI}}{ }_{7} \mathrm{O}_{30}\right]^{5-}$ formation. ${ }^{205}$

\section{Anderson-like polyoxometalates}

584 While classical Anderson-type structure for POMos and POTs cannot be reduced as they contain type II POMs, one-pot solvothermal reaction with organic ligands and reducing agent leads to formation of fully reduced Anderson-like functionalized POVs and POMos. In these anions $V$ or Mo ions form double bonds only with one terminal oxygen and thus have free orbital to accept extra electron (FIG. 1 d). Up to now fourteen reduced Anderson-like POVs ${ }^{206-212}$ and seventeen POMos ${ }^{213-229}$, which accept six electrons, were crystallized and investigated by single-crystal XRD so far (TABLE S7).

In 1987 Huang et al. reported the first synthesis of hexanuclear oxovanadium (IV) anion $\left[\left(\mathrm{V}^{\mathrm{IV}} \mathrm{O}\right)_{6}\left(\mathrm{CO}_{3}\right)_{4}(\mathrm{OH})_{9}\right]^{5-}$ from 590 $\mathrm{VOCl}_{2}$ and $\mathrm{NH}_{4} \mathrm{HCO}_{3}$ under $\mathrm{CO}_{2}$ atmosphere. ${ }^{211}$ The $\left[\left(\mathrm{V}^{\mathrm{IV}} \mathrm{O}\right)_{6}\left(\mathrm{CO}_{3}\right)_{4}(\mathrm{OH})_{9}\right]^{5-}$ is consolidated by bridging hydroxo and carbonato groups, one of which is situated in the centre of the anion. Khan et al. synthesized a series of POVs polyoxocations $\left[\mathrm{MV}_{6}{ }_{6}^{\mathrm{IV}} \mathrm{O}_{6}\left\{\left(\mathrm{OCH}_{2} \mathrm{CH}_{2}\right)_{2} \mathrm{~N}\left(\mathrm{CH}_{2} \mathrm{CH}_{2} \mathrm{OH}\right)\right\}_{6}\right]^{\mathrm{nt}}(\mathrm{M}=\mathrm{Li}, \mathrm{Na}, \mathrm{Mg}, \mathrm{Mn}, \mathrm{Fe}, \mathrm{Co}, \mathrm{Ni}){ }^{206}$ The cyclic fragment $\left\{\mathrm{MV}_{6} \mathrm{~N}_{6} \mathrm{O}_{18}\right\}$ adopts the Anderson-type structure: ${ }^{230}$ by exhibiting a ring of six $\mathrm{VO}_{5} \mathrm{~N}$ octahedral linked to a central $\mathrm{MO}_{6}(\mathrm{M}=\mathrm{Li}, \mathrm{Na}, \mathrm{Mg}, \mathrm{Mn}, \mathrm{Co}, \mathrm{Ni})$ unit (FIG. 1 d).

Four Anderson-like alkoxo-POVs anions $\left[\mathrm{V}_{6}^{\mathrm{IV}} \mathrm{O}_{6}\left(\mathrm{OCH}_{3}\right)_{9}\left(\mu_{6}-\mathrm{SO}_{4}\right)(\mathrm{COO})_{3}\right]^{2-}$ can serve as 3-connected second building units that assemble with dicarboxylate or tricarboxylate ligands to form a new family of metal organic tetrahedrons $\left\{\left[\mathrm{V}_{6} \mathrm{O}_{6}\left(\mathrm{OCH}_{3}\right)_{9}\left(\mathrm{SO}_{4}\right)\right]_{4}(\mathrm{~L})_{6}\right\}^{8-}\left(\mathrm{L}=\mathrm{BDC}, \mathrm{BDC}-\mathrm{NH}_{2}, \mathrm{BDC}-\mathrm{Br}\right){ }^{210}$ The similar behaviour demonstrated vanadium(V)-centered anion $\left[\mathrm{V}_{6}^{\mathrm{V}}{ }_{6} \mathrm{O}_{6}\left(\mathrm{OCH}_{3}\right)_{9}\left(\mathrm{~V}^{\mathrm{V}} \mathrm{O}_{3}\right)\left(\mathrm{H}_{2} \mathrm{O}\right)(\mathrm{COO})_{3}\right]^{-}$, adopting discrete truncated tetrahedral cage geometry. ${ }^{209}$

The synthesis of new families of functionalized POMos with cyclic cores of $\mathrm{Mo}^{\mathrm{V}}$ and localized Mo-Mo bonds was initiated by Haushalter and Lai ${ }^{213-217}$ and developed by several groups. The fully-oxidized class with the general formula $\left\{\mathrm{X}_{4} \mathrm{Mo}_{6}{ }_{6} \mathrm{E}_{6}\right\}$ (FIG. $1 \mathrm{~d}$ ) can accommodate various central and peripheral $X$ groups such as $\left\{\mathrm{PO}_{4}\right\},\left\{\mathrm{C}_{6} \mathrm{H}_{5} \mathrm{PO}_{3}\right\},\left\{\mathrm{C}_{6} \mathrm{H}_{5} \mathrm{AsO}_{3}\right\}$ and $602\left\{\mathrm{CO}_{3}\right\}$. The system was later extended to the oxothio chemistry by the synthesis of anions such as $\left[\mathrm{X}_{4} \mathrm{Mo}_{6} \mathrm{~S}_{6} \mathrm{O}_{6}\left(\mathrm{OH}_{3}\right]^{5-}\right.$ $603\left(\mathrm{X}=\mathrm{HPO}_{4}, \mathrm{HAsO}_{4}\right)^{220,221}$ where six sulfur atoms were inserted in the bridging positions of the dimolybdenum pairs. 
The hydroxyphospate anions $\left[\mathrm{Mo}_{6}^{\mathrm{V}} \mathrm{P}_{4} \mathrm{X}_{31}\right]^{\mathrm{n}-}(\mathrm{X}=\mathrm{O}, \mathrm{OH})$ tend to form dimers through joined metal ions $\left(\mathrm{Na},{ }^{214,218,222}\right.$, $\left.\mathrm{Mn}^{11223}, \mathrm{Co}^{11224}, \mathrm{Ni}^{11225,226}, \mathrm{Zn}^{11215}, \mathrm{Fe}^{111},{ }^{216} \mathrm{Cd}^{\prime \prime},{ }^{219,226}\right)$. The $\mathrm{Mo}^{\mathrm{V}}$ centers of the $\left\{\mathrm{Mo}_{6}{ }_{6} \mathrm{O}_{24}\right\}$ core exhibit strongly interacting pairs

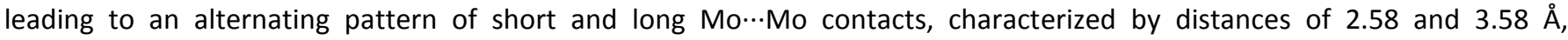
respectively. ${ }^{218}$ These anions exhibit reversible redox behaviour and are active catalysts for the reduction of $\mathrm{Fe}^{\mathrm{III}}$ in solution, ${ }^{226}$ nitrite, hydrogen peroxide and ascorbic acid ${ }^{224}$ and for the oxidation of acetaldehyde with $\mathrm{H}_{2} \mathrm{O}_{2} .{ }^{223}$

The hydrothermal synthesis of the molybdenum transition metal phosphate system can not only lead to the formation of the $\left\{\mathrm{P}_{4} \mathrm{Mo}_{6}{ }_{6}^{\mathrm{V}}\right\}$ family but also to wheel-like structures $\left\{\mathrm{Mo}_{16}{ }_{16} \mathrm{M}_{\mathrm{x}} \mathrm{P}_{26}\right\}\left(\mathrm{x}=16-\mathrm{M}=\mathrm{Co}^{112}{ }^{227}, \mathrm{Ni}^{11}{ }^{228} ; \mathrm{x}=14-\mathrm{M}=\mathrm{Ni}^{11}{ }^{229}\right)$ with a strong $\mathrm{M}^{\prime \prime}-\mathrm{M}^{\prime \prime}$ antiferromagnetic interactions (for $\mathrm{Ni}^{\prime \prime} \mathrm{g}=2.25$ and $\mathrm{J}=-24.3 \mathrm{~cm}^{-1228}$ ).

\section{Vanadates of the $\left\{\mathrm{V}_{\mathbf{1 8}} \mathrm{O}_{\mathbf{4 2}}\right\}$ archetypes}

614 The mixed-valence vanadium isopolyanions form a structurally unusually versatile cluster family due to the variation in the amount of $V^{\mathrm{IV}}$ and $\mathrm{V}^{\mathrm{V}}$ and the coordination geometries of the $\mathrm{V}$ centers (tetrahedral $\mathrm{V}^{\mathrm{V}}$, tetragonal-pyramidal $\mathrm{V}^{\mathrm{IV}} / \mathrm{V}^{\mathrm{V}}$, and octahedral $V^{I V} / V^{V}$ ). The formation of supramolecular host-guest complexes with interesting topologies is possible by linking of $\mathrm{O}_{4} \mathrm{~V}=\mathrm{O}$ square pyramids sharing corners and edges via their basal oxo groups, which was demonstrated by the structures of $\left\{V^{I V}{ }_{18} \mathrm{O}_{42}\right\}$ and $\left\{\mathrm{V}^{\mathrm{IV} /{ }_{15} \mathrm{O}_{36}}\right.$ (FIG. $1 \mathrm{~d}$ ). ${ }^{231-234}$ These compounds demonstrate a very strong antiferromagnetic coupling via the $\mu$ oxo groups, while their frontier orbitals strongly interact with the single-occupied molecular orbitals of the involved vanadyl groups $(S=1 / 2)$ and thus act as very efficient superexchange ligands. ${ }^{235}$ However, excited multiplet magnetic states can only be populated significantly at very high temperatures at which the related compounds might already decompose, thus inhibiting their experimental characterization. To partially overcome this obstacle the introduction of non-magnetic spacer groups connected to the POV can be applied. Since the discovery of the arsenato-polyoxovanadate compound $\mathrm{K}_{6}\left[\mathrm{As}_{6} \mathrm{~V}^{\mathrm{IV}}{ }_{15} \mathrm{O}_{42}\left(\mathrm{H}_{2} \mathrm{O}\right)\right] \cdot 8 \mathrm{H}_{2} \mathrm{O}{ }^{236}$ a great number of $\mathrm{As}, \mathrm{Sb}$, $\mathrm{Si}$ and Ge derivatives of the isopolyoxovanadate $\left\{\mathrm{V}_{18} \mathrm{O}_{42}\right\}$ archetype were reported. ${ }^{237-246}$

In this review we provide a brief overall picture of this type of POVs. The structural aspects, key properties and synthetic routes of Si-POVs, Ge-POVs, As-POVs and Sb-POVs, of which central structural motifs are typically derived from the $\left\{\mathrm{V}_{18} \mathrm{O}_{42}\right\}$ archetype, were reviewed recently. ${ }^{247}$

A typical example for host systems for small guests are polyvanadate cluster anions with an approximately spherical $\left\{\mathrm{V}_{18} \mathrm{O}_{42}\right\}$ shell, which can be synthesized under relatively mild conditions applying an inert atmosphere. ${ }^{232,234}$ Interestingly, the $\left\{\mathrm{V}_{18} \mathrm{O}_{42}\right\}$ shell can exist as two different structural types: either with a distorted rhombicuboctahedron or a so-called pseudorhombicuboctahedron (the "14th Archimedean body") geometry (FIG. 1 d). The first type has $T_{d}$ symmetry and can be regarded as an enlarged Keggin ion, in which all square planes of the rhombicuboctahedron are spanned by the 24 innershell $\mu_{3}$-oxygen atoms, which in turn are capped by $\{\mathrm{VO}\}$ units. The second type has an idealized $D_{4 d}$ symmetry. ${ }^{234}$

The spherical $\left\{\mathrm{V}_{18} \mathrm{O}_{42}\right\}$ shell principally represents a kind of container that can incorporatedifferent species below a critical sizesuch as $\mathrm{H}_{2} \mathrm{O}$, halides, formate or nitrite. The type of encapsulation can depend on the $\mathrm{pH}$ value: in a highly basic medium ( $\mathrm{pH}$ 14) only a $\mathrm{H}_{2} \mathrm{O}$ molecule is enclosed, whereas at lower $\mathrm{pH}$ values anionic species are preferentially encapsulated. $232,234,248,249$ 
There are three types of $\left\{\mathrm{X}_{2 \mathrm{x}} \mathrm{V}_{18-\mathrm{x}} \mathrm{O}_{42}\right\}$ structures with $\mathrm{x}$ being 2, 3 or 4. The first described $\left[\mathrm{As}^{\mathrm{II \prime \prime}}{ }_{6} \mathrm{~V}^{\mathrm{IV}}{ }_{15} \mathrm{O}_{42}\left(\mathrm{H}_{2} \mathrm{O}\right)\right]^{6-}$ anion ${ }^{236}$ as well as other $\left\{\mathrm{X}_{6} \mathrm{~V}_{15}\right\}\left(\mathrm{X}=\mathrm{Sb},{ }^{237,238} \mathrm{Ge},{ }^{240}\right.$ and $\mathrm{Si}^{237}$ ) derivatives have crystallographic $D_{3}$ symmetry and consist of 15 distorted tetragonal $\mathrm{VO}_{5}$ pyramids and 6 trigonal $\mathrm{XO}_{3}$ pyramids (FIG. 1 d). The $15 \mathrm{VO}_{5}$ pyramids are linked via vertices and edges to each other and are connected to the $\mathrm{XO}_{3}$ groups solely through vertices. Two neighboring $\mathrm{XO}_{3}$ groups are joined via an oxygen bridge forming a handle-like $\mathrm{X}_{2} \mathrm{O}_{5}$ moiety. The structure of the clusters can be regarded as consisting of three different layers: \{six corner- and edge-sharing $\mathrm{VO}_{5}$ square pyramids $\}-\left\{\mathrm{V}_{3} \mathrm{X}_{6} \mathrm{O}_{28}\right\}-$ six corner- and edge-sharing $\mathrm{VO}_{5}$ square pyramids $\}$.

The structures of $\left\{\mathrm{X}_{4} \mathrm{~V}_{16}\right\}$ and $\left\{\mathrm{X}_{8} \mathrm{~V}_{14}\right\}\left(\mathrm{X}=\mathrm{As},{ }^{239,241} \mathrm{Sb}^{242,243} \mathrm{Ge}^{246}\right.$ and $\left.\mathrm{Si}^{, 244,245}\right)$ are built on the same principal as $\left\{\mathrm{V}_{15} \mathrm{X}_{6}\right\}$, that is, by replacing two diagonal $\mathrm{VO}_{5}$ square pyramids with two $\mathrm{X}_{2} \mathrm{O}_{5}$ groups.

The geometrically frustrated structure of $\left\{\mathrm{V}^{\mathrm{IV}}{ }_{15} \mathrm{As}^{\mathrm{II \prime}}{ }_{6}\right\}$ exhibits highly interesting magnetic and redox properties. The triangle is sandwiched by two smaller $V_{6}{ }_{6}$ hexagons (FIG. 1 d). The 15 spins $(S=1 / 2)$ are coupled by antiferromagnetic superexchange and Dzyaloshinsky-Moriya interactions via different pathways, which results in a collective low spin ground state with $S=1 / 2 .{ }^{36}$ Studies of the adiabatic magnetization and quantum dynamics show that the $\left\{\mathrm{As}^{\mathrm{III}}{ }_{6} \mathrm{~V}^{\mathrm{IV}}{ }_{15}\right\}$ cluster can act as a qubit with relatively long coherence lifetimes and exhibits phonon bottleneck-induced magnetization hysteresis. ${ }^{36,235,250,251}$

\section{Conclusions and outlook}

The majority of studies in the area of electron-rich POMs has hitherto been focused on bulk synthesis and characterisation, however, great progress has been made recently in investigating their potentials as catalysts (see e.g. ref new computational methodologies to investigate and understand the mechanisms of POM reduction is gaining momentum. ${ }^{132,166,252}$ There is considerable interest in the integration of electron-rich POMs into biological systems as they were shown to exhibit enhanced biological activity in comparison to their oxidized parent structures. For example, tuning of redox state of Keggin mixed-metal Mo/V POMs is a dominating factor in the functionality of chemical and biological selfdetoxifying materials. ${ }^{253}$ Gaining real-time information about the properties of the different redox states (e.g., their optical properties via spectro- electrochemical methods) is of high interest.

Despite a number of crucial challenges at both the fundamental and applied levels, the structural characteristics of reduced POMs are highly advantageous and an enormous future potential exists to revolutionize a number of research fields such as electro- and photocatalysis, magnetochemistry, nanochemistry and biology, amongst others.

\section{Acknowledgements}


6732 Wang, S. S. \& Yang, G. Y. Recent advances in polyoxometalate-catalyzed reactions. Chem. Rev. 115, 4893-4962 (2015).

6743 Lv, H. et al. Polyoxometalate water oxidation catalysts and the production of green fuel. Chem. Soc. Rev. 41, 7572-89 675 (2012).

6764 Yamase, T. \& Pope, M. T. in Polyoxometalate chemistry for nano-composite design; (Kluwer, Dordrecht, 2002). .

6775 Sarafianos, S. G., Kortz, U., Pope, M. T. \& Modak, M. J. An analysis with HIV-1 reverse transcriptase indicates specificity 678 for the DNA-binding cleft. Reactions 626, 619-626 (1996).

6796 Rhule, J. T., Hill, C. L., Judd, D. \& Schinazi, R. F. Polyoxometalates in Medicine. Chem. Rev. 98, $327-358$ (1998)7.

6807 Bijelic, A. \& Rompel, A. The use of polyoxometalates in protein crystallography - An attempt to widen a well-known 681 bottleneck. Coord. Chem. Rev. 299, 22-38 (2015).

6828 Bijelic, A. \& Rompel, A. Ten good reasons for the use of the tellurium-centered Anderson-Evans polyoxotungstate in 683 protein crystallography. Acc. Chem. Res. 50, 1441-1448 (2017).

6849 Molitor, C., Bijelic, A. \& Rompel, A. The potential of hexatungstotellurate(VI) to induce a significant entropic gain during 685 protein crystallization. IUCrJ 4, 734-740 (2017) .

686

10 Sadakane, M. \& Steckhan, E. Electrochemical properties of polyoxometalates as electrocatalysts. Chem. Rev. 98, 219-237 687 (1998).

688

11 Proust, A., Thouvenot, R. \& Gouzerh, P. Functionalization of polyoxometalates: towards advanced applications in catalysis 689

690

691

692

693

694

695

696 and materials science. Chem. Commun. 16, 1837-1852 (2008).

12 Clemente-Juan, J. M., Coronado, E. \& Gaita-Ariño, A. Magnetic polyoxometalates: from molecular magnetism to molecular spintronics and quantum computing. Chem. Soc. Rev. 41, 7464-7478 (2012).

13 Botar, B., Ellern, A., Hermann, R. \& Kögerler, P. Electronic control of spin coupling in keplerate-type polyoxomolybdates. Angew. Chemie - Int. Ed. 48, 9080-9083 (2009).

14 Baker, L. C. W. \& Glick, D. C. Present general status of understanding of heteropoly electrolytes and a tracing of some major highlights in the history of their elucidation. Chem. Rev. 98, 3-50 (1998).

15 Müller, A. \& Serain, C.Soluble Molybdenum Bluess“des Pudels Kern”. Acc. Chem. Res. 33, 2-10 (2000).

697

16 Müller, A. et al. $\left[\mathrm{Mo}_{154}(\mathrm{NO})_{14} \mathrm{O}_{420}(\mathrm{OH})_{28}\left(\mathrm{H}_{2} \mathrm{O}\right)_{70}\right]^{(25 \pm 5)-}$ : A water-soluble big wheel with more than 700 atoms and a relative 698 molecular mass of about 24 000. Angew. Chemie Int. Ed. English 34, 2122-2124 (1995).

699

17 Piepgrass, K. \& Pope, M. T. Oxygen atom transfer chemistry of heteropolytungstate 'browns' in nonaqueous solvents. J. 700 Am. Chem. Soc. 111, 753-754 (1989).

701

18 Piepgrass, K. \& Pope, M. T. Heteropoly' brown' as class I mixed valence (W (IV, VI)) complexes. Tungsten-183 NMR of W 702 (IV) trimers. J. Am. Chem. Soc. 109, 1586-1587 (1987).

703

19 Pope, M. T. Heteropoly and isopoly anions as oxo complexes and their reducibility to mixed-valence blues. Inorg. Chem.

704 11, 1973-1974 (1972).

705

20 Nomiya, K. \& Miwa, M. Structural stability index of heteropoly- and isopoly-anions. Polyhedron 3, 341-346 (1984).

706

21 Yamase, T.Photo- and electrochromism of polyoxometalates and related materials. Chem. Rev. 98, 307-325 (1998). .

707

22 Yamase, T. Photochemical studies of the alkylammonium molybdates. Part 6. Photoreducible octahedron site of 708 $\left[\mathrm{Mo}_{7} \mathrm{O}_{24}\right]^{6-}$ as determined by electron spin resonance. Dalton Trans., 1987-1991 (1982).

23 Aparicio, P. A., Poblet, J. M. \& Lõpez, X. Tungsten redox waves in $\left[\mathrm{XMW}_{11} \mathrm{O}_{40}\right]^{\mathrm{n}-}(\mathrm{X}=\mathrm{P}, \mathrm{Si}, \mathrm{Al}$ and $\mathrm{M}=\mathrm{W}, \mathrm{Mo}, \mathrm{V}, \mathrm{Nb}, \mathrm{Ti})$ 
Keggin compounds - Effect of localised/delocalised charges. Eur. J. Inorg. Chem. 1910-1916 (2013).

24 Maeda, K., Katano, H., Osakai, T., Himeno, S. \& Saito, A. Charge dependence of one-electron redox potentials of Keggintype heteropolyoxometalate anions. J. of Electroanal. Chem., 389, 167-173 (1995).

25 Tian, A.-X. et al. A series of polyoxometalate-based compounds including infinite $\mathrm{Ag}$ belts and circles constructed by two tolyl-1H-tetrazole isomers. RSC Adv. 5, 53757-53765 (2015).

26 Müller, A. et al. [Mo(V) $\left.)_{12} \mathrm{O}_{30}\left(\mu_{2}-\mathrm{OH}\right)_{10} \mathrm{H}_{2}\left\{\mathrm{Ni}(\mathrm{II})\left(\mathrm{H}_{2} \mathrm{O}\right)_{3}\right\}_{4}\right]$, a highly symmetrical $\varepsilon$-Keggin unit capped with four $\mathrm{Ni}(\mathrm{II})$ centers: Synthesis and magnetism. Inorg. Chem. 39, 5176-5177 (2000).

27 Renneke, R. F., Pasquali, M. \& Hill, C. L. Polyoxometalate systems for the catalytic selective production of nonthermodynamic alkenes from alkanes. nature of excited-state deactivation processes and control of subsequent thermal processes in polyoxometalate photoredox chemistry. J. Am. Chem. Soc. 112, 6585-6594 (1990).

28 Papaconstantinou, E. Photochemistry of polyoxometallates of molybdenum and tungsten and/or vanadium. Chem. Soc. Rev. 18, 1-31 (1989).

29 Bagherjeri, F. A. et al. Mixed-Metal hybrid polyoxometalates with amino acid ligands: electronic versatility and solution properties. Inorg. Chem. 55, 12329-12347 (2016).

30 Poblet, J. M., Lopez, X. \& Bo, C. Ab initio and DFT modelling of complex materials: towards the understanding of electronic and magnetic properties of polyoxometalates. Chem. Soc. Rev. 32, 297-308 (2003).

31 Zhang, C. et al. A hybrid polyoxometalate-organic molecular catalyst for visible light driven water oxidation. Chem. Commun. (Camb). 50, 11591-4 (2014).

32 Haviv, E., Shimon, L. J. W. \& Neumann, R. Photochemical reduction of $\mathrm{CO}_{2}$ with visible light using a polyoxometalate as photoreductant. Chem. Eur. J., 23, 92-95 (2016).

33 Yang, B., Pignatello, J. J., Qu, D. \& Xing, B. Reoxidation of photoreduced polyoxotungstate $\left(\left[\mathrm{PW}_{12} \mathrm{O}_{40}\right]^{4-}\right)$ by different oxidants in the presence of a model pollutant. Kinetics and reaction mechanism. J. Phys. Chem. A 119, 1055-1065 (2015).

34 Cao, G. et al. Organic-inorganic heteropoly blue based on Dawson-type molybdosulfate and organic dye and its characterization and application in electrocatalysis. Electrochim. Acta 106, 465-471 (2013).

35 Lehmann, J., Gaita-Ariño, A., Coronado, E. \& Loss, D. Spin qubits with electrically gated polyoxometalate molecules. Nat. Nanotechnol. 2, 312-317 (2007).

36 Bertaina, S. et al. Quantum oscillations in a molecular magnet. Nature 453, 203-206 (2008).

37 Wang, Y. \& Weinstock, I. A. Polyoxometalate-decorated nanoparticles. Chem. Soc. Rev. 41, 7479-7496 (2012).

38 Yamase, T. Anti-tumor, -viral, and -bacterial activities of polyoxometalates for realizing an inorganic drug. J. Mater. Chem. 15, 4773 (2005).

39 Ogata, A. et al. Antitumour effect of polyoxomolybdates: induction of apoptotic cell death and autophagy in in vitro and in vivo models. Br. J. Cancer 98, 399-409 (2008).

$40 \mathrm{Xu}, \mathrm{X}$. et al. A combined crystallographic analysis and ab initio calculations to interpret the reactivity of functionalized hexavanadates and their inhibitor potency toward Na+/K+-ATPase. J. Inorg. Biochem. 161, 27-36 (2016).

41 Wang, H. et al. In operando X-ray absorption fine structure studies of polyoxometalate molecular cluster batteries: Polyoxometalates as electron sponges. J. Am. Chem. Soc. 134, 4918-4924 (2012).

42 Kortz, U. et al. Polyoxometalates: Fascinating structures, unique magnetic properties. Coord. Chem. Rev. 253, 2315-2327 
(2009).

748

749

750

751

752

753

754

755

756

757

758

759

760

761

762

763

764

765

766

767

768

769

770

771

772

773

774

775

776

777

778

779

780

781

782

783
43 Müller, A. \& Roy, S. En route from the mystery of molybdenum blue via related manipulatable building blocks to aspects of materials science. Coord. Chem. Rev. 245, 153-166 (2003).

44 Müller, A. \& Gouzerh, P. From linking of metal-oxide building blocks in a dynamic library to giant clusters with unique properties and towards adaptive chemistry. Chem. Soc. Rev. 41, 7431-7463 (2012).

45 Hill, C. L. et al. Catalytic photochemical oxidation of organic substrates by polyoxometalates. picosecond spectroscopy, photochemistry, and structural properties of charge-transfer complexes between heteropolytungstic acids and dipolar organic compounds. J. Am. Chem. Soc. 110, 5471-5419 (1988).

46 Le Maguers, P., Hubig, S. M., Lindeman, S. V., Veya, P. \& Kochi, J. K. Novel charge-transfer materials via cocrystallization of planar aromatic donors and spherical polyoxometalate acceptors. J. Am. Chem. Soc. 122, 10073-10082 (2000).

47 Buckley, R. I. \& Clark, R. J. H. Structural and electronic properties of some polymolybdates reducible to molybdenum blues. Coord. Chem. Rev. 65, 167-218 (1985).

48 Sanchez, C., Livage, J., Launay, J. P., Fournier, M. \& Jeannin, Y. Electron delocalization in mixed-valence molybdenum polyanions. J. Am. Chem. Soc. 104, 3194-3202 (1982).

49 Che, M., Fournier, M. \& Launay, J. P. The analog of surface molybdenyl ion in $\mathrm{Mo} / \mathrm{SiO}_{2}$ supported catalysts: The isopolyanion $\mathrm{Mo}_{6} \mathrm{O}_{19}{ }^{3-}$ studied by EPR and UV-visible spectroscopy. Comparison with other molybdenyl compounds. J. Chem. Phys. 71, 1954-1960 (1979).

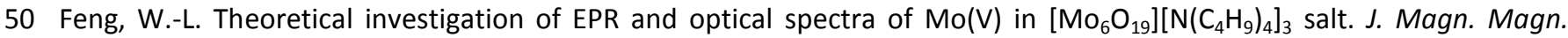
Mater. 324, 4061-4063 (2012).

51 Proust, A., Robert, F., Gouzerh, P., Chen, Q. \& Zubieta, J. Reduced nitrosyl polyoxomolybdates with the hitherto unknown decamolybdate $\mathrm{Y}$ structure: Preparation and crystal and electronic structures of the two-electron reduced $\left[\mathrm{Mo}_{10} \mathrm{O}_{25}(\mathrm{OMe})_{6}(\mathrm{NO})\right]^{-}$and the four-electron reduced $\left[\mathrm{Mo}_{10} \mathrm{O}_{24}(\mathrm{OMe})_{7}(\mathrm{NO})\right]^{2-}$. J. Am. Chem. Soc. 119, 3523-3535 (1997).

52 Wang, L. et al. $\chi$-octamolybdate $\left[\mathrm{Mo}_{4}{ }_{4} \mathrm{MoO}_{4}{ }_{4} \mathrm{O}_{24}\right]^{4-}$ : An unusual small polyoxometalate in partially reduced form from nonaqueous solvent reduction. Chem. - A Eur. J. 17, 4796-4801 (2011).

53 Yamase, T. \& Ishikawa, E. Photoreductive self-assembly from $\left[\mathrm{Mo}^{\mathrm{VI}} \mathrm{O}_{24}\right]^{6-}$ to Anti-Tumoral $\left[\mathrm{H}_{2} \mathrm{Mo}_{12}^{\mathrm{V}} \mathrm{O}_{28}(\mathrm{OH})_{12}\left(\mathrm{Mo}^{\mathrm{VI}} \mathrm{O}_{3}\right)_{4}\right]^{6-}$ in aqueous media. Bull. Chem. Soc. Jpn. 81, 983-991 (2008).

54 Long, D. L., Kögerler, P., Farrugia, L. J. \& Cronin, L. Restraining symmetry in the formation of small polyoxomolybdates: Building blocks of unprecedented topology resulting from 'shrink-wrapping' $\left[\mathrm{H}_{2} \mathrm{Mo}_{16} \mathrm{O}_{52}\right]^{10-}$ type clusters. Angew. Chemie - Int. Ed. 42, 4180-4183 (2003).

55 Khan, M. I. et al. Cation Inclusion within the mixed-valence polyanion cluster $\left[\left(\mathrm{Mo}^{\mathrm{V}} \mathrm{O}_{3}\right)_{4} \mathrm{Mo}^{\mathrm{V}}{ }_{12} \mathrm{O}_{28}(\mathrm{OH})_{12}\right]^{8-}$ : syntheses and structures of $\left(\mathrm{NH}_{4}\right)_{7}\left[\mathrm{NaMo}_{16}(\mathrm{OH})_{12} \mathrm{O}_{40}\right] 4 \mathrm{H}_{2} \mathrm{O}$ and $\left(\mathrm{Me}_{2} \mathrm{NH}_{2}\right)_{6}\left[\mathrm{H}_{2} \mathrm{Mo}_{16}(\mathrm{OH})_{12} \mathrm{O}_{40}\right]$. Angew. Chemie Int. Ed. 32, 1780-1782 (1993).

56 Cotton, F. A., Marler, D. O. \& Schwotzer, W. New routes to the preparation of the aquomolybdenum (IV) ion by comproportionation reactions. Inorg. Chem., 23, 3671-3673 (1984).

57 Chen, W.-P., Sang, R.-L., Wang, Y. \& Xu, L. An unprecedented $\left[\mathrm{Mo}_{3}^{\mathrm{IV}} \mathrm{O}_{4}\right]$-incorporated polyoxometalate concomitant with $\mathrm{MoO}_{2}$ nucleophilic addition. Chem. Commun. 49, 5883 (2013). 
58 Launay, J. P. Reduction de l'ion metatungstate: Stades eleves de reduction de $\mathrm{H}_{2} \mathrm{~W}_{12} \mathrm{O}_{40}{ }^{6-}$, derives de l'ion $\mathrm{HW}_{12} \mathrm{O}_{40}{ }^{7-}$ et discussion generale. J. Inorg. Nucl. Chem. 38, 807-816 (1976).

59 Khan, I. M., Cevik, S., Doedens, R. J. \& O'Connor, C. J. Hydrothermal synthesis and characterization of mixed-valence hexatungstates: crystal structures of $\left[\left(\mathrm{C}_{2} \mathrm{H}_{5}\right)_{4} \mathrm{~N}\right]_{3}\left[\mathrm{~W}^{\mathrm{V}} \mathrm{W}_{5}^{\mathrm{V} /} \mathrm{O}_{19}\right] \cdot 0.5 \mathrm{H}_{2} \mathrm{O}$ and $[\mathrm{H} 3 \mathrm{~N}(\mathrm{CH} 2) 2 \mathrm{NH} 3] 2$ $\left[\mathrm{W}^{\mathrm{V}} \mathrm{W}_{5}{ }^{\mathrm{Vl}} \mathrm{O}_{19}\right] \cdot\left[\mathrm{H}_{2} \mathrm{~N}\left(\mathrm{CH}_{2}\right)_{2} \mathrm{NH}_{2}\right] \mathrm{Cl} \cdot 8 \mathrm{H}_{2} \mathrm{O}$. Inorganica Chim. Acta 277, 69-75 (1998).

60 Yang, W. B. et al. Synthesis, structural characterization, and magnetic properties of a new charge-transfer salt composed of polyoxotungstate acceptors $\left[\mathrm{W}^{\mathrm{V}} \mathrm{W}^{\mathrm{Vl}}{ }_{5} \mathrm{O}_{19}\right]^{3-}$ and cationic ferrocenyl $\mathrm{CpFe}{ }^{+} \mathrm{Cp}$ donors. J. Clust. Sci. 14, 421-430 (2003).

61 Kazansky, L. P. \& Launay, J. P. X-ray photoelectron study of mixed valence metatungstate anions. Chem. Phys. Lett., 51, 242-245 (1977).

62 Smith, S. P. E. \& Christian, J. B. Mechanism of the coupled 24-electron reduction and transformations among the 'blues', the 'browns' and the 'reds' of ammonium metatungstate. Electrochim. Acta 53, 2994-3001 (2008).

63 Bond, A. M., Boskovic, C., Sadek, M. \& Brownlee, R. T. C. Electrosynthesis and solution structure of six-electron reduced forms of metatungstate, $\left[\mathrm{H}_{2} \mathrm{~W}_{12} \mathrm{O}_{40}\right]^{6-}$. J. Chem. Soc. Dalt. Trans. 2, 187-196 (2001).

64 Jeannin, Y., Launay, J. P. \& Sedjadi, M. A. S. Crystal molecular structure of the six-electron-reduced form of metatungstate $\mathrm{Rb}_{4} \mathrm{H}_{8}\left(\mathrm{H}_{2} \mathrm{~W}_{12} \mathrm{O}_{40}\right)\left(\mathrm{H}_{2} \mathrm{O}\right)_{18}$ occurrence of a metal-metal bonded subcluster in a heteropolyanion framework. Inorg. Chem. 19, 2933-2935 (1980).

65 Dickman, M. H. et al. Polyoxometalates from heteropoly 'brown' precursors. A new structural class of mixed valence heteropolytungstates, $\left[\left(\mathrm{XO}_{4}\right) \mathrm{W}^{\mathrm{IV}}{ }_{3} \mathrm{~W}^{\mathrm{V}}{ }_{17} \mathrm{O}_{62} \mathrm{H}_{\mathrm{x}}\right]^{\mathrm{n}-}$. J. Chem. Soc. Dalt. Trans. 149-154 (2000).

66 Christian, J. B., Smith, S. P. E., Whittingham, M. S. \& Abruña, H. D. Tungsten based electrocatalyst for fuel cell applications. Electrochem. commun. 9, 2128-2132 (2007).

67 Tanielian, C. Decatungstate Photocatalysis. Coord. Chem. Rev. 178, 1165-1181 (1998).

68 Fuchs, J., Hartl, H., Schiller, W. \& Gerlach, U. Die Kristallstruktur des Tributylammoniumdekawolframats $\left[\left(\mathrm{C}_{4} \mathrm{H}_{9}\right)_{2} \mathrm{NH}\right]_{4} \mathrm{~W}_{10} \mathrm{O}_{32}$. Acta Crystallogr. Sect. B Struct. Crystallogr. Cryst. Chem. 32, 740-749 (1976).

69 Chemseddine, A., Sanchez, C., Livage, J., Launay, J. P. \& Fournier, M. Electrochemical and photochemical reduction of decatungstate: a reinvestigation. Inorg. Chem. 23, 2609-2613 (1984).

70 Yamase, T. Involvement of hydrogen-bonding protons in delocalization of the paramagnetic electron in a single crystal of photoreduced decatungstate. J. Chem. Soc. Dalton Trans., 1597-1604 (1987).

71 Sasaki, Y., Yamase, T., Ohashi, Y. \& Sasada, Y. Structural retention of decatungstate upon photoreduction. Bulletin of the Chemical Society of Japan 60, 4285-4290 (1987).

72 Duncan, D. C. \& Hill, C. L. Synthesis and characterization of the mixed-valence diamagnetic two-electron-reduced isopolytungstate $\left[\mathrm{W}_{10} \mathrm{O}_{32}\right]^{6-}$. Evidence for an asymmetric d-electron distribution over the tungsten sites. Inorg. Chem. 35, 5828-5835 (1996).

73 Combs-Walker, L.A. \& Hill, C. L. Use of excited-state and ground-state redox properties of polyoxometalates for selective transformation of unactivated carbon-hydrogen centers remote from the functional group in ketones. J. Am. Chem. Soc. 114, 938-946 (1992).

74 Sattari D. \& Hill, C. L. Catalytic carbon-halogen bond cleavage chemistry by redox-active polyoxometalates. J. Am. Chem. Soc. 115, 4649-4651 (1993). 
821

822

823

824

825

826

827

828

829

830

831

832

833

834

835

836

837

838

839

840

841

842

843

844

845

846

847

848

849

850

851

852

853

854

855

856

857

75 Tzirakis, M. D., Lykakis, I. N. \& Orfanopoulos, M. Decatungstate as an efficient photocatalyst in organic chemistry. Chem. Soc. Rev. 38, 2609-21 (2009).

76 Duncan, D. C. \& Fox, M. A. Early events in decatungstate photocatalyzed oxidations: a nanosecond laser transient absorbance reinvestigation. J. Phys. Chem. A 5639, 4559-4567 (1998).

77 Tanielian, C., Seghrouchni, R. \& Schweitzer, C. Decatungstate photocatalyzed electron-transfer reactions of alkenes. Interception of the geminate radical ion pair by oxygen. J. Phys. Chem. A 107, 1102-1111 (2003).

78 Khan, M. I. \& Zubieta, J. Oxovanadium and oxomolybdenum clusters and solids incorporating oxygen-donor ligands Progr. Inorg. Chem., 43, 1-149 (1995).

79 Chen, Q. et al. Coordination-compounds of polyoxovanadates with a hexametalate core - chemical and structural characterization of $\left[\mathrm{V}_{6}^{\mathrm{V}} \mathrm{O}_{13}\left\{\left(\mathrm{OCH}_{2}\right)_{3} \mathrm{CR}\right\}_{2}\right]^{2-}, \quad\left[\mathrm{V}_{6}^{\mathrm{V}} \mathrm{O}_{11}(\mathrm{OH})_{2}\left\{\left(\mathrm{OCH}_{2}\right)_{3} \mathrm{CR}\right\}_{2}\right], \quad\left[\mathrm{V}^{\mathrm{IV}}{ }_{4} \mathrm{~V}_{2}^{\mathrm{V}} \mathrm{O}_{9}(\mathrm{OH})_{4}\left\{\left(\mathrm{OCH}_{2}\right)_{3} \mathrm{CR}\right\} 2\right]^{2-}$, and $\left[\mathrm{V}_{6}{ }_{6} \mathrm{O}_{7}(\mathrm{OH})_{6}\left\{\left(\mathrm{OCH}_{2}\right)_{3} \mathrm{CR}\right\}_{2}\right]^{2-}$. J. Am. Chem. Soc. 114, 4667-4681 (1992).

80 Khan, M. I. et al. Hydrothermal synthesis and characterization of hexavanadium polyoxo alkoxide anion clusters - crystalstructures of the vanadium(IV) species $\mathrm{Ba}\left[\mathrm{V}_{6} \mathrm{O}_{7}(\mathrm{OH})_{3}\left\{\left(\mathrm{OCH}_{2}\right)_{3} \mathrm{CCH}_{3}\right)_{3}\right] \cdot 3 \mathrm{H}_{2} \mathrm{O}$ and $\mathrm{Na}_{2}\left[\mathrm{~V}_{6} \mathrm{O}_{7}\left\{\left(\mathrm{OCH}_{2}\right)_{3} \mathrm{CCH}_{2} \mathrm{CH}_{3}\right\}_{4}\right]$, of the mixedvalence complex $\left(\mathrm{Me}_{3} \mathrm{NH}\right)\left[\mathrm{V}_{5}^{\mathrm{IV}} \mathrm{V}^{\mathrm{V}} \mathrm{O}_{7}(\mathrm{OH})_{3}\left\{\left(\mathrm{OCH}_{2}\right)_{3} \mathrm{CCH}_{3}\right\}_{3}\right]$ and of the fluoro derivative $\mathrm{Na}\left[\mathrm{V}_{6} \mathrm{O}_{6} \mathrm{~F}(\mathrm{OH})_{3}\left\{\left(\mathrm{OCH}_{2}\right)_{3} \mathrm{CCH}_{3}\right\}_{3}\right]$ $\cdot 3 \mathrm{H}_{2} \mathrm{O}$. Inorg. Chem. 32, 2929-2937 (1993).

81 Och, R., Khan, M. I., Chen, Q., Goshom, D. P. \& Zubieta, J. Polyoxo Alkoxide clusters of vanadium: structural characterization of the decavanadate core in the "fully reduced" vanadium(IV) species $\left[\mathrm{V}_{10} \mathrm{O}_{16}\left\{\left(\mathrm{OCH}_{2}\right)_{3} \mathrm{CCH}_{2} \mathrm{CH}_{3}\right\}_{4}\right]^{4-}$ and $\left[\mathrm{V}_{10} \mathrm{O}_{14}\left\{\left(\mathrm{OCH}_{2}\right)_{3} \mathrm{CCH}_{2} \mathrm{OH}\right\}_{4}\right]^{2-}$ and in the mixed-valence clusters $\left[\mathrm{V}_{8}^{\mathrm{IV}} \mathrm{V}_{2}^{\mathrm{V}} \mathrm{O}_{16}\left\{\left(\mathrm{OCH}_{2}\right)_{3} \mathrm{CR}\right\}_{4}\right]^{2-}\left(\mathrm{R}=-\mathrm{CH}_{2} \mathrm{CH}_{3},-\mathrm{CH} 3\right)$. Inorg. Chem. 32, 672-680 (1993).

82 Müller, A., Meyer, J., Bögge, H., Stammler, \& Botar, A. A. Cis-/trans-isomerie bei Bis-(trisa1koxy)-hexavanadaten: cis$\mathrm{Na}_{2}\left[\mathrm{~V}_{6}^{\mathrm{IV}} \mathrm{O}_{7}(\mathrm{OH})_{6}\left\{\left(\mathrm{OCH}_{2}\right)_{3} \mathrm{CCH}_{2} \mathrm{OH}\right\} 2\right] \cdot 8 \mathrm{H}_{2} \mathrm{O}$, cis- $\left(\mathrm{CN}_{3} \mathrm{H}_{6}\right)_{3}\left[\mathrm{~V}^{\mathrm{IV} V} \mathrm{~V}_{5}^{\mathrm{V}} \mathrm{O}_{13}\left\{\left(\mathrm{OCH}_{2}\right) \mathrm{CCH}_{2} \mathrm{OH}\right\}_{2}\right] \cdot 4,5 \mathrm{H}_{2} \mathrm{O}$ und trans$\left(\mathrm{CN}_{3} \mathrm{H}_{6}\right) 2\left[\mathrm{~V}_{6}{ }_{6} \mathrm{O}_{13}\left\{\left(\mathrm{OCH}_{2}\right) \mathrm{CCH}_{2} \mathrm{OH}\right\}_{2}\right] \cdot \mathrm{H}_{2} \mathrm{O}$. Z. Anorg. Allg. Chem. 621, 1818-1831 (1995).

83 Daniel, C. \& Hartl, H. Neutral and cationic $V^{\mathrm{VV}} / \mathrm{V}^{\mathrm{V}}$ mixed-valence alkoxo-polyoxovanadium clusters $\left[\mathrm{V}_{6} \mathrm{O}_{7}(\mathrm{OR})_{12}\right]^{\mathrm{nt}}\left(\mathrm{R}=-\mathrm{CH}_{3}\right.$, $-\mathrm{C}_{2} \mathrm{H}_{5}$ ): Structural, cyclovoltammetric and IR-spectroscopic investigations on mixed valency in a hexanuclear core. J. Am. Chem. Soc. 127, 13978-13987 (2005).

84 Augustyniak-Jablokow, M. A., Daniel, C., Hartl, H., Spandl, J. \& Yablokov, Y. V. Exchange interactions and electron delocalization in the mixed-valence cluster $\mathrm{V}_{4}{ }^{\mathrm{IV}} \mathrm{V}_{2}{ }^{\mathrm{V}} \mathrm{O}_{7}\left(\mathrm{OC}_{2} \mathrm{H}_{5}\right)_{12}$. Inorg. Chem. 47, 322-332 (2008).

85 Spandl, J., Daniel, C., Brüdgam, I. \& Hartl, H. Synthesis and structural characterization of redox-active dodecamethoxoheptaoxohexavanadium clusters. Angew. Chemie - Int. Ed. 42, 1163-1166 (2003).

86 Khan, M. I. et al. Polyoxo alkoxides of vanadium - the structures of the decanuclear vanadium(IV) clusters $\left[\mathrm{V}_{10} \mathrm{O}_{16}\left(\mathrm{CH}_{3} \mathrm{CH}_{2} \mathrm{C}\left(\mathrm{CH}_{2} \mathrm{O}\right)_{3}\right)_{4}\right]^{4-}$ and $\left[\mathrm{V}_{10} \mathrm{O}_{13}\left(\mathrm{CH}_{3} \mathrm{CH}_{2} \mathrm{C}\left(\mathrm{CH}_{2} \mathrm{O}\right)_{3}\right)_{5}\right]$. J. Am. Chem. Soc. 114, 3341-3346 (1992).

87 Daniel, C. \& Hartl, H. A mixed-valence $V^{I V} / V^{V}$ alkoxo-polyoxovanadium cluster series $\left[\mathrm{V}_{6} \mathrm{O}_{8}\left(\mathrm{OCH}_{3}\right)_{11}\right]^{\mathrm{n}+-}$ : exploring the influence of a $\mu$-oxo ligand in a spin frustrated structure. J. Am. Chem. Soc. 131, 5101-5114 (2009).

88 Aronica, C. et al. A mixed-valence polyoxovanadate(III,IV) cluster with a calixarene cap exhibiting ferromagnetic V(III)V(IV) interactions. J. Am. Chem. Soc. 130, 2365-2371 (2008).

89 Li, F., Vangelder, L. E., Brennessel, W. W. \& Matson, E. M. Self-assembled, iron-functionalized polyoxovanadate alkoxide clusters. Inorg. Chem. 55, 7332-7334 (2016). 
90 Li, F. et al. Polyoxovanadate-alkoxide clusters as a redox reservoir for iron. Inorg. Chem. 56, 7065-7080 (2017).

91 Qin, C. \& Zubieta, J. Structural investigations of the hexavanadium core $\left\{\mathrm{V}_{6} \mathrm{O}_{19}\right\}$ in 'oxidized', mixed valence and 'reduced' clusters of the type $\left[\mathrm{V}_{6-\mathrm{n}}^{\mathrm{V}} \mathrm{V}_{\mathrm{n}}^{\mathrm{IV}} \mathrm{O}_{13-\mathrm{n}}(\mathrm{OH})_{n}\left\{\left(\mathrm{OCH}_{2}\right)_{3} \mathrm{CR}\right\}_{2}\right]^{2-}, \mathrm{n}=0,3$ and 6. Inorganica Chim. Acta 198-200, 95-110 (1992).

92 Heitner-Wirguin, C. \& Selbin, J. A new mixed valence compound of vanadium. J. Inorg. Nucl. Chem., 30, 3181-3188 (1968).

93 Bino, A., Cohen S. \& Heitner-Wirguin, C. Molecular structure of a mixed-valence isopolyvanadate. Inorg. Chem., 21, 429431 (1982).

94 Baxter, S. M. \& Wolczanski, P. T. Improved synthesis, redox chemistry, and magnetism of the mixed-valence isopolyanion of vanadate $\mathrm{V}_{10} \mathrm{O}_{26}{ }^{4-}$. Inorg. Chem. 28, 3263-3264 (1989).

95 Hayashi, Y., Miyakoshi, N., Shinguchi, T. \& Uehara, A. A Stepwise Growth of Polyoxovanadate by Reductive Coupling Reaction with Organometallic Palladium Complex: Formation of $\left[\left\{\left(\eta_{3}-\mathrm{C}_{4} \mathrm{H}_{7}\right) P d\right\}_{2} \mathrm{~V}_{4} \mathrm{O}_{12}\right]^{2-},\left[\mathrm{V}_{10} \mathrm{O}_{26}\right]^{4-}$ and $\left[\mathrm{V}_{15} \mathrm{O}_{36}(\mathrm{Cl})\right]^{4-}$. Chem. Lett. 36, 170-171 (2001).

96 Kurata, T., Uehara, A., Hayashi, Y. \& Isobe, K. Cyclic Polyvanadates incorporating template transition metal cationic species: synthesis and structures of hexavanadate $\left[\mathrm{PdV}_{6} \mathrm{O}_{18}\right]^{4-}$, octavanadate $\left[\mathrm{Cu}_{2} \mathrm{~V}_{8} \mathrm{O}_{24}\right]^{4-}$, and decavanadate $\left[\mathrm{Ni}_{4} \mathrm{~V}_{10} \mathrm{O}_{30}(\mathrm{OH})_{2}\left(\mathrm{H}_{2} \mathrm{O}\right)_{6}\right]^{4-}$. Inorg. Chem. 44, 2524-2530 (2005).

97 Forster, J., Rösner, B., Khusniyarov, M. M. \& Streb, C. Tuning the light absorption of a molecular vanadium oxide system for enhanced photooxidation performance. Chem. Commun. 47, 3114-3116 (2011).

98 Okaya, K., Kobayashi, T., Koyama, Y., Hayashi, Y. \& Isobe, K. Formation of $V^{V}$ lacunary polyoxovanadates and interconversion reactions of dodecavanadate species. Eur. J. Inorg. Chem. 5156-5163 (2009).

99 Sun, H.-R., Zhang, S.-Y., Xu, J.-Q., Yang, G.-Y. \& Shi, T.-S. Electrochemical and in-situ UV-visible-near-IR and FTIR spectroelectrochemical characterisation of the mixed-valence heteropolyanion $\mathrm{PMo}_{12} \mathrm{O}_{40}{ }^{\mathrm{n}-}(\mathrm{n}=4,5,6,7)$ in aprotic media. J. Electroanal. Chem. 455, 57-68 (1998)

100 Maksimovskaya, R. I. Molybdophosphate heteropoly blues: Electron-transfer reactions in aqueous solutions as studied by NMR. Polyhedron 65, 54-59 (2013).

101 Barrows, J. N., Jameson, G. B. \& Pope, M. T. T. Structure of a heteropoly blue. The four-electron reduced $\beta$-12molybdophosphate anion. J. Am. Chem. Soc. 107, 1771-1773 (1985).

$102 \mathrm{Vu}, \mathrm{T} .$, Bond, A. \& Hockless, D. Electrochemical synthesis and structural and physical characterization of one-and twoelectron-reduced forms of $\left[\mathrm{SMo}_{12} \mathrm{O}_{40}\right]^{2-}$. Inorg. Chem. 40, 65-72 (2001).

103 Yuan, M. et al. Modified polyoxometalates: Hydrothermal syntheses and crystal structures of three novel reduced and capped Keggin derivatives decorated by transition metal complexes. Inorg. Chem. 42, 3670-3676 (2003).

104 Bakri, R. et al. Rational addition of capping groups to the phosphomolybdate Keggin anion $\left[\mathrm{PMo}_{12} \mathrm{O}_{40}\right]^{3-}$ by mild, nonaqueous reductive aggregation. Chem. Comm. 48, 2779-2781 (2012).

$105 \mathrm{Dai}$, L. et al. Hydrothermal synthesis and crystal structure of two new $\alpha$-Keggin derivatives decorated by transition metal complexes. Transit. Met. Chem. 31, 340-346 (2006).

106 Tian, A.-X. et al. Subtly tuning one $\mathrm{N}$ site of benzyl-1H-triazole ligands to build mono-nuclear subunits and tri-nuclear clusters to modify polyoxometalates. CrystEngComm 17, 5569-5578 (2015).

107 Chen, W. \& Mi, J. A new redox-based approach for synthesizing a mixed-valence hybrid polymolybdate uncommonly 
bicapped by $\mathrm{Cr}$ ( III ) coordination complexes. Polyhedron 85, 117-123 (2015).

108 Dong, B.-X. et al. Synthesis, crystal structure and electrochemical properties of a new 2D network containing linear $\{\varepsilon-$ $\left.\mathrm{H}_{2} \mathrm{PMo}_{8}{ }^{\mathrm{V}} \mathrm{Mo}_{4}{ }^{\mathrm{V}} \mathrm{O}_{40} \mathrm{Zn}_{4}\right\}_{\infty}$ inorganic chain. J. Clust. Sci. 27, 361-371 (2016).

$109 \mathrm{Yu}, \mathrm{H} .-\mathrm{H}$. et al. Hydrothermal synthesis and structural characterization of the first mixed molybdenum-tungsten cappedkeggin polyoxometal complex: $\left\{[\mathrm{Co}(\text { dien })]_{4}\left[\left(\mathrm{As}^{\mathrm{V}} \mathrm{O}_{4}\right) \mathrm{Mo}_{8}^{\mathrm{V}} \mathrm{W}^{\mathrm{VI}}{ }_{4} \mathrm{O}_{33}\left(\mu_{2}-\mathrm{OH}\right)_{3}\right]\right\} \cdot 2 \mathrm{H}_{2} \mathrm{O}$. Dalton Trans. 33, 195-197 (2008).

110 Wang, W., Xu, L., Gao, G., Liu, L. \& Liu, X. The first $\varepsilon$-Keggin core of molybdogermanate in extended architectures of nickel(II) with N-donor ligands: Syntheses, crystal structures and magnetic properties. CrystEngComm 11, 2488-2493 (2009).

111 Cui, X. B., Zheng, S. T. \& Yang, G. Y. First Nickel(II) cation inclusion within the mixed-valence polyoxomolybdate capped with four Nill(en)(H2O) groups: Hydrothermal synthesis and structure of $\left[\mathrm{Mo}^{\mathrm{V}}{ }_{8} \mathrm{Mo}^{\mathrm{VI}}{ }_{4} \mathrm{O}_{30}\left(\mathrm{\mu}_{2}-\mathrm{OH}\right)_{6}\left(\mathrm{Ni}^{\prime \prime} \mathrm{O}_{4}\right)\left\{\mathrm{Ni}^{\prime \prime}(\mathrm{en})\left(\mathrm{H}_{2} \mathrm{O}\right)\right\}_{4}\right]$. Zeitschrift fur Anorg. und Allg. Chemie 631, 642-644 (2005).

112 Han, X., Zhang, Z., Zhang, T., Li, Y. \& Lin, W. Polyoxometalate-based cobalt- phosphate molecular catalysts for Visible Light-Driven Water Oxidation. J. Am. Chem. Soc. 136, 5359-5366 (2014).

113 Keita, B. et al. $\mathrm{Mo}^{\mathrm{V}}-\mathrm{Mo}^{\mathrm{VI}}$ mixed valence polyoxometalates for facile synthesis of stabilized metal nanoparticles electrocatalytic oxidation of alcohols. J. Phys. Chem. C, 111, 8145-8148 (2007).

114 Roch-Marchal, C., Hidalgo, T., Banh, H., Fischer, R. A. \& Horcajada, P. A promising catalytic and theranostic agent obtained through the in-situ synthesis of au nanoparticles with a reduced polyoxometalate incorporated within mesoporous MIL101. Eur. J. Inorg. Chem. 2016, 4387-4394 (2016).

115 Zhang, G. et al. Synthesis of various crystalline gold nanostructures in water: The polyoxometalate $\beta-\left[\mathrm{H}_{4} \mathrm{PMo}_{12} \mathrm{O}_{40}\right]^{3-}$ as the reducing and stabilizing agent. J. Mater. Chem. 19, 8639 (2009).

116 Nakamura, I., Tsunashima, R., Nishihara, S., Inouebc, K. \& Akutagawad T. A dielectric anomaly observed for doubly reduced mixed-valence polyoxometalate. Chem. Commun. 53, 6824-6827 (2017).

117 Pope, M. T. \& Varga, G. M. Heteropoly blues. I. reduction stoichiometries and reduction potentials of some 12-tungstates. Inorg. Chem. 5, 1249-1254 (1966).

118 Varga, G. M., Papaconstantinou, E. \& Pope, M. T. Heteropoly blues. IV. Spectroscopic and magnetic properties of some reduced polytungstates. Inorg. Chem. 9, 662-667 (1970).

119 Wang, Z., Gao, S., Xu, L., Shen, E. \& Wang, E. Synthesis and structural characterization of a tungstophosphate heteropoly blue. Polyhedron, 15, 1383-1388 (1996).

120 Li, N. \& Huang, R. Six new inorganic - organic hybrids based on rigid triangular ligandSyntheses, structures and properties. J. Solid State Chem. 233, 320-328 (2016).

121 Zhao, C. et al. A molecular crown analogue templated by Keggin polyanions: synthesis, structure, and electrochemical and luminescent properties. Zeitschrift für Naturforsch. B 70, 547-553 (2015).

122 Zhang, X. et al. Steric hindrance-dependent rational design and synthesis of three new Keggin-based supramolecular networks. Dalt. Trans. 42, 9198-9206 (2009).

123 Wang, J., Shen, Y. \& Niu, J. Hydrothermal synthesis and crystal structure of a novel compound supported by $\alpha$-Keggin units $\left[\mathrm{Cu}\left(2,2^{\prime} \text {-bipy }\right)_{2}\right]\left\{\mathrm{W}^{\mathrm{V}}{ }_{40}\left[\mathrm{Cu}\left(2,2^{\prime} \text {-bipy }\right)_{2}\right]_{2}\right\} \cdot 2 \mathrm{H}_{2}$ O. J. Coord. Chem. 59, 1007-1014 (2006). 
932

933

934

935

936

937

938

939

940

941

942

943

944

945

946

947

948

949

950

951

952

953

954

955

956

957

958

959

960

961

962

963

964

965

966

967

968

124 Casañ-Pastor, N., Gomez-Romero, P., Jameson, G. B. \& Baker, L. C. W. Crystal structures of $\alpha-\left[\mathrm{Co}^{11} \mathrm{~W}_{12} \mathrm{O}_{40}\right]^{6-}$ and its heteropoly blue $2 \mathrm{e}$ reduction product, $\alpha-\left[\mathrm{Co}^{\prime \prime} \mathrm{W}_{12} \mathrm{O}_{40}\right]^{8-}$. Structural, electronic, and chemical consequences of electron delocalization in a multiatom mixed-valence system. J. Am. Chem. Soc. 113, 5658-5663 (1991).

125 Geletii, Y. V et al. Electron exchange between alpha-Keggin tungstoaluminates and a well-defined cluster-anion probe for studies in electron transfer. Inorg. Chem. 44, 8955-66 (2005).

126 Canny, J., Liu, F.-X. \& Hervé, G. Electrochemical synthesis and stability of the brown six-electron reduced $\beta$ - and $\gamma$-12tungstosilicates. C.R. Chim. 8, 1011-1016 (2005).

127 Suaud, N., Gaita-Ariño, A., Clemente-Juan, J. M., Sánchez-Marín, J. \& Coronado, E. Electron delocalization in mixedvalence Keggin polyoxometalates. Ab initio calculation of the local effective transfer integrals and its consequences on the spin coupling. J. Am. Chem. Soc. 124, 15134-15140 (2002).

128 Troupis, A., Hiskia, A. \& Papaconstantinou, E. Synthesis of metal nanoparticles by using polyoxometalates as photocatalysts and stabilizers. Angew. Chem. Int. Ed. 41, 1911-1914 (2002).

129 Cevik, S., Alkan, Z., Poyraz, M., Sari, M. \& Buyukgungor, O. Hydrothermal synthesis and characterization of $\left(\mathrm{N}\left(\mathrm{C}_{2} \mathrm{H}_{5}\right)_{4}\right)_{4}\left[\mathrm{VMo}_{12} \mathrm{~V}_{2} \mathrm{O}_{44}\right]$. Cryst. Res. Technol. 42, 955-960 (2007).

130 Sha, J. et al. Asymmetrical Polar Modification of a Bivanadium-Capped Keggin POM by Multiple C $\mathrm{H}$ Coordination Polymeric Chains. Inorg. Chem. 46, 11183-11189 (2007).

131 Chen, Q. \& Hill, C. L. A bivanadyl capped, highly reduced Keggin polyanion, $\left[\mathrm{PMo}{ }_{6} \mathrm{Mo}^{\mathrm{VI}}{ }_{6} \mathrm{O}_{40}\left(\mathrm{~V}^{\mathrm{IV}} \mathrm{O}\right)_{2}\right]^{5-}$. Inorg. Chem. 35, 2403-2405 (1996).

132 Maestre, J. M., Poblet, J. M., Bo, C., Casan-Pastor, N. \& Gomez-Romero, P. Electronic structure of the highly reduced polyoxoanion $\left.\left[\mathrm{PMo}_{12} \mathrm{O}_{40}(\mathrm{VO})_{2}\right)\right]^{5-}:$ A DFT study. Inorg. Chem. 37, 3444-3446 (1998).

$133 \mathrm{Gu}, \mathrm{X}$. et al. Target syntheses of saturated Keggin polyoxometalate-based extended solids. Inorganica Chim. Acta 358, 3701-3710 (2005).

134 Shi, Z., Peng, J., Gómez-García, C. J., Benmansour, S. \& Gu, X. Influence of metal ions on the structures of Keggin polyoxometalate-based solids: Hydrothermal syntheses, crystal structures and magnetic properties. J. Solid State Chem. 179, 253-265 (2006).

135 Sha, J. et al. Target syntheses of two new bivanadyl capped Keggin polyoxometalate derivatives. J. Clust. Sci. 19, 499-509 (2008).

136 Shi, Z., Gu, X., Peng, J. \& Chen, Y. Controlled assembly of two new bicapped bisupporting Keggin-polyoxometalate derivatives: $\left[\mathrm{M}\left(2,2^{\prime}-\mathrm{bpy}\right)_{2}\left(\mathrm{H}_{2} \mathrm{O}\right)\right]_{2}\left[\mathrm{SiMo}_{8}^{\mathrm{VI}} \mathrm{Mo}_{4}{ }_{4} \mathrm{~V}_{2}^{\mathrm{IV}}{ }_{2} \mathrm{O}_{42}\right](\mathrm{M}=\mathrm{Co}, \mathrm{Zn})$. J. Solid State Chem., 2005, 178, $1988-1995$.

137 Liu, C.-M., Zhang, D.-Q. \& Zhu, D.-B. One- and two-dimensional coordination polymers constructed from bicapped keggin mixed molybdenum-vanadium heteropolyoxoanions and polynuclear copper(I) clusters bridged by asymmetrical bipyridine (2,4'-bipy and 2,3'-bipy) ligands. Crystal Growth \& Design, 6, 524-529 (2006).

138 Dai, L. et al. A novel two-dimensional mixed molybdenum-vanadium polyoxometalate: Synthesis, magnetic property and characterization of \{Mathematical expression\}. J. Mol. Struct. 829, 74-79 (2007).

$139 \mathrm{Yu}, \mathrm{Y}$. et al. Two novel zipper-like compounds of the usual and bivanadyl capped Keggin clusters connected by propellershaped complexes. New J. Chem. 38, 1271-1276 (2014).

140 Yao, S., Zhang, Z., Li, Y. \& Wang, E. Two dumbbell-like polyoxometalates constructed from capped molybdovanadate and 
transition metal complexes. Inorganica Chim. Acta 363, 2131-2136 (2010).

141 Ding, Y., Meng, J.-X., Chen, W.-L. \& Wang, E.-B. Controllable assembly of four new POM-based supramolecular compounds by altering the POM secondary building units from pseudo-Keggin to classical Keggin. CrystEngComm 13, 2687 (2011).

142 Meng, J.-X., Lu, Y., Li, Y.-G., Fu, H. \& Wang, E.-B. Controllable self-assembly of four new metal-organic frameworks based on different phosphomolybdate clusters by altering the molar ratio of $\mathrm{H}_{3} \mathrm{PO}_{4}$ and $\mathrm{Na}_{2} \mathrm{MoO}_{4}$. CrystEngComm 13, 2479 (2011).

$143 \mathrm{Shi}$, S. et al. OD and 1D dimensional structures based on the combination of polyoxometalates, transition metal coordination complexes and organic amines. CrystEngComm 12, 2122-2128 (2010).

144 Lu, Y., Wang, E., Guo, Y., Xu, X. \& Xu, L. Hydrothermal synthesis and crystal structure of a hybrid material based on $\left[\mathrm{Cu}_{4}(\mathrm{bpy})_{4}\left(\mathrm{H}_{2} \mathrm{O}\right)_{2}\left(\mathrm{PO}_{4}\right)_{2}\right]^{2+}$ and an $\alpha-K e g g i n$ polyoxoanion. J. Mol. Struct. 737, 183-187 (2005).

145 Lu, Y., Li, Y. G., Ma, Y., Wang, E. B. \& Xu, X. X. Hydrothermal synthesis and crystal structure of two new modified polyoxometalates based on $\mathrm{PMo}_{8} \mathrm{~V}_{6} \mathrm{O}_{42}$ clusters. Transit. Met. Chem. 31, 708-713 (2006).

146 Lin, S. et al. A polymeric chain formed by bicapped pseudo-Keggin polyoxometalate and [Ni(en)2]2+ complexes: synthesis, structure and catalytic properties of $\left\{\left[\mathrm{H}_{3} \mathrm{PMo}_{8} \mathrm{~V}_{6} \mathrm{O}_{46}\right]\left[\mathrm{Ni}(\mathrm{en})_{2}\right]\right\} \cdot 2\left[\mathrm{Ni}(\mathrm{en})_{2}\right] \cdot 5 \mathrm{H}_{2} \mathrm{O}$. J. Coord. Chem. 61, 167-177 (2008).

147 Li, F. Y. et al. A novel cobalt(II) complex with polyoxometalate-based ligand by virtue of coexistence of both a cappedKeggin anion and a neutral unit. J. Coord. Chem. 58, 1751-1758 (2005).

148 Li, F., Xu, L., Wei, Y. \& Wang, E. A new polyoxometalate-based complex with alternate ionic layer structures: Hydrothermal synthesis, crystal structure and magnetic property. Inorg. Chem. Commun. 8, 263-266 (2005).

149 Lan, Q., Zhang, Z.-M., Li, Y.-G., Lu, Y. \& Wang, E.-B. Synthesis of a poly-pendant 1-D chain based on 'trans-vanadium' bicapped, Keggin-type vanadtungstate and its photocatalytic properties. Dalton Trans. 43, 16265-9 (2014).

150 Guo, G., Xu, Y., Cao, J. \& Hu, C. An unprecedented vanadoniobate cluster with 'trans-vanadium' bicapped Keggin-type $\left\{\mathrm{VNb}_{12} \mathrm{O}_{40}(\mathrm{VO})_{2}\right\}$. Chem. Commun. 47, 9411-9413 (2011).

151 Son, J. H., Ohlin, C. A., Larson, E. C., Yu, P. \& Casey, W. H. Synthesis and characterization of a soluble vanadium-containing keggin polyoxoniobate by ESI-MS and ${ }^{51} \mathrm{~V}$ NMR: (TMA) ${ }_{9}\left[\mathrm{~V}_{3} \mathrm{Nb}_{12} \mathrm{O}_{42}\right] \cdot 18 \mathrm{H}_{2} \mathrm{O}$. Eur. J. Inorg. Chem. 1748-1753 (2013).

152 Dolbecq, A., Cadot, E., Eisner, D. \& Secheresse, F. Hydrothermal syntheses: A route to the stepwise condensation of reduced Keggin polyanions. From reduced beta- $\left[\mathrm{H}_{\mathrm{m}} \mathrm{SiMo}_{12} \mathrm{O}_{40}\right]^{\mathrm{n}-}$ monomers to bicapped dimerized $\left[\mathrm{Si}_{2} \mathrm{Mo}_{28} \mathrm{O}_{84}\left(\mathrm{H}_{2} \mathrm{O}\right)_{2}\right]^{6-}$ anions. Inorg. Chem. 38, 4217-4223 (1999).

$153 \mathrm{Han}, \mathrm{Z}$.-G. et al. An Unusual Metallic Oxygen Cluster Consisting of a $\left\{\mathrm{AlMo}_{12} \mathrm{O}_{40}\left(\mathrm{MoO}_{2}\right)\right\}$. Inorg. Chem. 53, 670-672 (2014). 154 Mei, H., Yan, D., Chen, Q., Xu, Y. \& Sun, Q. Hydrothermal synthesis, structure characterization and catalytic property of a new 1-D chain built on bi-capped Keggin type mix-valence molybdenum compound: $\left(\mathrm{NH}_{4}\right)\left[\mathrm{Mo}_{6}{ }_{6}^{\mathrm{V}} \mathrm{Mo}_{6}{ }_{6} \mathrm{O}_{36}\left(\mathrm{As}^{\mathrm{V}} \mathrm{O}_{4}\right) \mathrm{Mo}^{\mathrm{V}}\left(\mathrm{Mo}^{\mathrm{V}} \mathrm{O}\right)\right]$. Inorganica Chim. Acta 363, 2265-2268 (2010).

155 Zhang, Q. B. et al. Synthesis and characterization of the first polyoxometalate possessing bicapped by antimony alphaKeggin structure $\left(\mathrm{C}_{2} \mathrm{~N}_{2} \mathrm{H}_{9}\right)_{2}\left[\left(\mathrm{PMo}_{5}{ }_{5} \mathrm{Mo}^{\mathrm{VI}}{ }_{7} \mathrm{Sb}^{\prime \prime \prime}{ }_{2} \mathrm{O}_{40}\right) \cdot 2 \mathrm{H}_{2} \mathrm{O}\right.$. Inorg. Chem. Commun. 9, 544-547 (2006).

$156 \mathrm{Shi}$, S.-Y. et al. First examples of extended structures based on $\left\{\mathrm{PMo}_{12} \mathrm{Sb}_{2} \mathrm{O}_{40}\right\}$ polyoxoanions. Dalt. Trans. 39, 1389-1394 (2010).

157 Liu, Y. B. et al. Hydrothermal synthesis and characterization of three one-dimensional chain materials formed by reduced 
tetra-capped Keggin polyoxoanions and $\left[\mathrm{M}(\mathrm{en})_{2}\right]^{2+}(\mathrm{M}=\mathrm{Cu}$, Co and Ni) cations. J. Mol. Struct. 825, 45-52 (2006).

158 Sun, Y. H. et al. Hydrothermal synthesis and crystal structural characterization of two new modified polyoxometalates constructed of positive and negative metal-oxo cluster ions. J. Mol. Struct. 740, 193-201 (2005).

$159 \mathrm{Li}, \mathrm{F}$. Y. et al. Arsenicum-centered molybdenum-vanadium polyoxometalates bearing transition metal complexes: Hydrothermal syntheses, crystal structures and magnetic properties. J. Mol. Struct. 753, 61-67 (2005).

160 Sun, Y.-H. et al. A new mixed molybdenum-vanadium polyoxometalate double-supporting transition metal complex: $\left\{\left[\mathrm{Co}(\text { phen })_{2}\right]_{2}-\mathrm{C}_{2} \mathrm{O}_{4}\right\}\left\{\mathrm{H}_{2} \mathrm{PO}_{44}\left[\mathrm{Co}(\text { phen })_{2}\left(\mathrm{H}_{2} \mathrm{O}\right)\right]_{2}\right\}$. J. Coord. Chem. 58, 1561-1571 (2005).

161 Liu, C.-M., Zhang, D.-Q., Xu, C.-Y. \& Zhu, D.-B. Two novel windmill-like tetrasupporting heteropolyoxometalates: $\left[\mathrm{Mo}^{\mathrm{VV}}{ }_{7} \mathrm{Mo}^{\mathrm{V} V \mathrm{~V}^{\mathrm{IV}}}{ }_{8} \mathrm{O}_{40}\left(\mathrm{PO}_{4}\right)\right]\left[\mathrm{M}(\text { phen })_{2}(\mathrm{OH})\right]_{2}\left[\mathrm{M}(\text { phen })_{2}(\mathrm{OEt})\right]_{2}(\mathrm{M}=\mathrm{Co}, \mathrm{Ni})$. Solid State Sci. 6, 689-696 (2004).

$162 \mathrm{Xu}, \mathrm{Y}$., Zhu, H., Cai, H. \& You, X. $\left[\mathrm{Mo}^{\mathrm{V}}{ }_{2} \mathrm{Mo}^{\mathrm{VI}}{ }_{6} \mathrm{~V}^{\mathrm{IV}}{ }_{8} \mathrm{O}_{40}\left(\mathrm{PO}_{4}\right)\right]^{5-}$ : the first polyanion with a tetra-capped Keggin structure. Chem. Comm. 40, 787-788 (1999).

163 Liu, C. M. et al. Spin glass behaviour in a 1D mixed molybdenum-vanadium heteropolyoxometalate-bridged coordination polymer. Eur. J. Inorg. Chem. 24, 4774-4779 (2004).

164 Liu, C. M., Zhang, D. Q., Xiong, M. \& Zhu, D. B. A novel two-dimensional mixed molybdenum-vanadium polyoxometalate with two types of cobalt(II) complex fragments as bridges. Chem. Commun. 853, 1416-1417 (2002).

165 Liu, C.-M., Zhang, D.-Q. \& Zhu, D.-B. 3D Supramolecular array assembled by cross-like arrangement of 1d sandwich mixed molybdenum-vanadium polyoxometalate bridged coordination polymer chains: hydrothermal synthesis and crystal structure of $\left\{\left[\mathrm{Mo}_{5}^{\mathrm{VV}}{ }_{5} \mathrm{Mo}_{3}{ }_{3} \mathrm{~V}^{\mathrm{IV}}{ }_{8} \mathrm{O}_{40}\left(\mathrm{PO}_{4}\right)\right]\left[\mathrm{Ni}(\mathrm{en})_{2}\right]\right\}\left[\mathrm{Ni}(\text { en })_{2}\right]_{2} \cdot 4 \mathrm{H}_{2} \mathrm{O}$. Cryst. Growth Des. 5, 1639-1642 (2005).

166 X. López, C. De Graaf, J. M. Maestre, M. Bénard, M.-M. Rohmer, C. Bo and J. M. Poblet, J. Chem. Theory Comput., 2005, 1, 856.

167 Barrows, J. N. \& Pope, M. T. Stabilization and magnetic resonance characterization of the one-electron heteropoly blue derivative of the molybdophosphate $\left[\mathrm{P}_{2} \mathrm{Mo}_{18} \mathrm{O}_{62}\right]^{6-}$. Slow intramolecular proton exchange of the two-electron blue in acetonitrile solution. Inorganica Chim. Acta 213, 91-98 (1993).

168 Kortz, U. \& Pope, M. T. Polyoxometalate-diphosphate complexes. 2. Structure of 18-molybdopyrophosphate, $\left[\left(\mathrm{P}_{2} \mathrm{O}_{7}\right) \mathrm{Mo}_{18} \mathrm{O}_{54}\right]^{4-}$, which encloses a linear, eclipsed conformation of the pyrophosphate anion, and preliminary characterization of its one- and two-electron heteropoly blues. Inorg. Chem. 33, 5643-5646 (1994).

169 Zhang, H., Yu,K., Wang, C., Su, Z., Wang, C., Sun, D., Cai, H., Chen, Z. \& Zhou, B. pH and ligand dependent assembly of Well-Dawson arsenomolybdate capped architectures. Inorg. Chem., 53, 12337-12347 (2014).

170 Way, D. M., Bond, A. M. \& Wedd, A. G. Multielectron reduction of $\alpha-\left[\mathrm{S}_{2} \mathrm{Mo}_{18} \mathrm{O}_{62}\right]^{4-}$ in aprotic and protic media: voltammetric studies. Inorg. Chem. 36, 2826-2833 (1997).

171 Cooper, J. B., Way, D. M., Bond, M. \& Wedd, G. A green heteropoly blue - isolation of a stable, odd oxidation level in a Dawson molybdate anion $\left[\mathrm{S}_{2} \mathrm{Mo}_{18} \mathrm{O}_{62}\right]^{5-}$. Inorg. Chem. 32, 2416-2420 (1993).

172 Neier, R., Trojanowski, C. \& Mattes, R. Reduced polyoxomolybdates with the Keggin and Dawson structures - preparation and crystal-structures of 2-electron reduced $\left[\mathrm{K}(18 \text {-crown-6) }]_{2}\left[\mathrm{~N}\left(\mathrm{Pph}_{3}\right)_{2}\right]_{2}\left[\mathrm{HPMo}_{12} \mathrm{O}_{40}\right] \cdot 8 \mathrm{MeCN} \cdot 18\right.$-crown-6 and 4-electron reduced $\left[\mathrm{NBu}_{4}{ }_{4}\right]_{5}\left[\mathrm{H}_{3} \mathrm{~S}_{2} \mathrm{Mo}_{18} \mathrm{O}_{62}\right] \cdot 4 \mathrm{MeCN}$ (1 8-crown-6 = I,4,7,10,13,16-hexaoxacyclooctadecane). J. Chem. Soc. Trans. 2521-2528 (1995).

173 Long, D. L., Kögerler, P. \& Cronin, L. Old clusters with new tricks: Engineering S ‥S interactions and novel physical 
properties in sulfite-based Dawson clusters. Angew. Chemie - Int. Ed. 43, 1817-1820 (2004).

174 Baffert, C., Feldberg, S. W., Bond, A. M., Long, D.-L. \& Cronin, L. pH-dependence of the aqueous electrochemistry of the two-electron reduced $\alpha$-[ $\left[\mathrm{Mo}_{18} \mathrm{O}_{54}\left(\mathrm{SO}_{3}\right)\right]$ sulfite Dawson-like polyoxometalate anion derived from its triethanolammonium salt. Dalton Trans. 54, 4599-607 (2007).

175 Baffert, C. et al. Experimental and theoretical investigations of the sulfite-based polyoxometalate cluster redox series: $\alpha$ and $\beta-\left[\mathrm{Mo}_{18} \mathrm{O}_{54}\left(\mathrm{SO}_{3}\right)_{2}\right]^{4-15-16-}$. Chem. - A Eur. J. 12, 8472-8483 (2006).

176 Long, D. L., Abbas, H., Kögerler, P. \& Cronin, L. Confined electron-transfer reactions within a molecular metal oxide 'Trojan Horse'. Angew. Chemie - Int. Ed. 44, 3415-3419 (2005).

177 Fay, N. et al. Structural, electrochemical, and spectroscopic characterization of a redox pair of sulfite-based polyoxotungstates: $\alpha-\left[\mathrm{W}_{18} \mathrm{O}_{54}\left(\mathrm{SO}_{3}\right)_{2}\right]^{4-}$ and $\alpha-\left[\mathrm{W}_{18} \mathrm{O}_{54}\left(\mathrm{SO}_{3}\right)_{2}\right]^{5-}$. Inorg. Chem. 46, 3502-10 (2007).

$178 \mathrm{Zhu}, \mathrm{S}$. et al. Synthesis and crystal structure determination of a novel a-Dawson mixed-valence octadecatungstoperchlorate. J. Chem. Soc., Dalt. Trans. 3633-3634 (1993).

179 Sun, W. et al. A new 3D framework based on reduced Wells-Dawson arsenotungstates as eight-connected linkages. RSC Adv., 4, 24755-24761 (2014).

180 Kozik, M., Hammer, C. F. \& Baker, L. C. W. NMR of 31P Heteroatoms in paramagnetic one-electron heteropoly blues. Rates of intra- and intercomplex electron transfers. Factors affecting line widths. J. Am. Chem. Soc. 108, 7627-7630 (1986).

181 Kozik, M. \& Baker, L. C. W. Electron-exchange reactions between heteropoly anions: Comparison of experimental rate constants with theoretically predicted values. J. Am. Chem. Soc. 112, 7604-7611 (1990).

182 Kozik, M., Casan-Pastor, N., Hammer, C. F. \& Baker, L. C. W. Ring currents in wholly inorganic heteropoly blue complexes. Evaluation by a modification of Evans' susceptibility method. J. Am. Chem. Soc. 110, 7697-7701 (1988).

183 Kozik, M., Hammer, C. F. \& Baker, L. C. W. Direct determination by ${ }^{183}$ W NMR of the locations of added electrons in ESRsilent heteropoly blues. Chemical Shifts and relaxation times in polysite mixed-valence transition-metal species. J. Am. Chem. Soc. 108, 2748-2749(1986).

184 Kirbyt, J. F. \& Baker, L. C. W. Evaluations of a general NMR method, based on properties of heteropoly blues, for determining rates of electron transfer through various bridges. New mixed-mixed valence complexes. J. Am. Chem. Soc. 117, 10010-10016 (1995).

185 Harmalker, S. P., Leparulo, M. \& Pope, M. T. Mixed-valence chemistry of adjacent vanadium centers in heteropolytungstate anions. I. Synthesis and electronic structures of mono-, di-, and trisubstituted derivatives of $\alpha-$ octadecatungstodiphosphate(6-) ion $\left(\alpha-\left[\mathrm{P}_{2} \mathrm{~W}_{18} \mathrm{O}_{62}\right]^{6-}\right)$. J. Am. Chem. Soc. 105, 4286-4292 (1983).

186 Contant, R. et al. Synthesis, characterization and electrochemistry of complexes derived from $\left[(1), 2,3-\mathrm{P}_{2} \mathrm{Mo}_{2} \mathrm{~W}_{15} \mathrm{O}_{61}\right]^{10-}$ and first transition metal ions. Eur. J. Inorg. Chem. 62, 567-574 (2000).

187 Mbomekalle, I. M. et al. Synthesis, characterization and electrochemistry of the novel Dawson-type tungstophosphate $\left[\mathrm{H}_{4} \mathrm{PW}_{18} \mathrm{O}_{62}\right]^{7-}$ and first transition metal ions derivatives. Eur. J. Inorg. Chem. 2, 276-285 (2004).

188 Keita, B., Mbomekalle, I. M., Nadjo, L. \& Haut, C. Tuning the formal potentials of new $\mathrm{V}^{\mathrm{IV}}$-substituted Dawson-type polyoxometalates for facile synthesis of metal nanoparticles. Electrochem. commun. 6, 978-983 (2004).

189 Keita, B. et al. Reactions of V-substituted polyoxometalates with L-cysteine. J. Clust. Sci. 17, 221-233 (2006). 
1080

1081

1082

1083

1084

1085

1086

1087

1088

1089

1090

1091

1092

1093

1094

1095

1096

1097

1098

1099

1100

1101

1102

1103

1104

1105

1106

1107

1108

1109

1110

1111

1112

1113

1114

1115

1116

190 Miras, H. N. et al. Solution identification and solid state characterisation of a heterometallic polyoxometalate $\left\{\mathrm{Mo}_{11} \mathrm{~V}_{7}\right\}$ : $\left[\mathrm{Mo}^{\mathrm{VI}}{ }_{11} \mathrm{~V}_{5}{ }_{5} \mathrm{~V}^{\mathrm{IV}}{ }_{2} \mathrm{O}_{52}\left(\mu_{9}-\mathrm{SO}_{3}\right)\right]^{7-}$. Chem. Commun. 52, 4703-4705 (2008).

191 Zhang, X., Wu, H. \& Zhang, F. The three-electron heteropoly blue $\left[\mathrm{P}_{6} \mathrm{Mo}_{18} \mathrm{O}_{73}\right]^{11-}$ with a basket- shaped skeleton. Chem. Commun., 2046-2047 (2004).

192 Zhang, F.-Q., Zhang, X.-M., Fang, R.-Q. \& Wu, H.-S. $\mathrm{P}_{6} \mathrm{Mo}_{18} \mathrm{O}_{73}$ heteropolyanion and its four-copper complex: theoretical and experimental investigation. Dalton Trans. 39, 8256-8260 (2010).

$193 \mathrm{Yu}$, K. et al. A Basket-Like $\left[\mathrm{SrCP}_{6} \mathrm{Mo}^{\mathrm{V}}{ }_{4} \mathrm{Mov}^{\mathrm{V}}{ }_{14} \mathrm{O}_{73}\right]^{10-}$ polyoxoanion modified with $\left\{\mathrm{Cu}(\mathrm{phen})\left(\mathrm{H}_{2} \mathrm{O}\right)_{\mathrm{x}}\right\}(\mathrm{x}=1-3)$ fragments: synthesis, structure, magnetic, and electrochemical properties. Eur. J. Inorg. Chem. 2007, 5662-5669 (2007).

194 Chen, Z. Y. et al. Nonclassical phosphomolybdates with different degrees of reduction: syntheses and structural and photo/electrocatalytic properties. Inorg. Chem. 55, 8309-8320 (2016).

195 Yu, K. et al. Supramolecular assembly based on Keggin cluster and basketlike cage. Inorg. Chem. Commun. 14, 1846-1849 (2011).

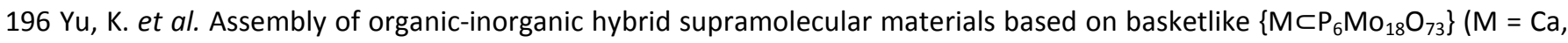
Sr, Ba) cage and transition-metal complex. Inorg. Chem. 52, 485-498 (2013).

$197 \mathrm{Yu}, \mathrm{K}$. et al. High-efficiency photo- and electro-catalytic material based on a basket-like $\left\{\mathrm{Sr}_{\mathrm{A}} \mathrm{P}_{6} \mathrm{Mo}_{18} \mathrm{O}_{73}\right\}$ cage. RSC Adv. 5, 59630-59637 (2015).

198 Zhang, H. et al. Organic-Inorganic hybrid materials based on basket-like $\left\{\mathrm{Ca} \subset \mathrm{P}_{6} \mathrm{Mo}_{18} \mathrm{O}_{73}\right\}$ cages. Inorg. Chem. 54, 67446757 (2015).

199 Deng, W., Zhang, Q. \& Wang, Y. Polyoxometalates as efficient catalysts for transformations of cellulose into platform chemicals. Dalt. Trans. 41, 9817 (2012).

200 Zhang, $\mathrm{H}$. et al. Assembly of a basket-like $\left\{\mathrm{SrCP}_{6} \mathrm{Mo}_{18} \mathrm{O}_{73}\right\}$ cage from OD dimmer to $2 \mathrm{D}$ network and its photo-/electrocatalytic properties. Dalton Trans. 44, 12839-12851 (2015).

201 Zhang, H. et al. 1,4-Bis(imidazole)butane ligand and strontium(II) directed 1-D chains based on basket-type molybdophosphates and transition metal (TM) linkers. CrystEngComm 17, 6110-6119 (2015).

202 Nakamura, I. et al. Investigating the formation of 'Molybdenum Blues' with gel electrophoresis and mass spectrometry. J. Am. Chem. Soc. 137, 6524-6530 (2015).

203 Fujibayashi, M., Song, Y.-F., Cronin, L. \& Tsunashima, R. Exploring the solvent mediated assembly and redox activity of a POM-organic hybrid $\left[\mathrm{Na}\left(\mathrm{SO}_{3}\right)_{2}\left(\mathrm{PhPO}_{3}\right)_{4} \mathrm{Mo}_{4}{ }_{4} \mathrm{MoO}_{14}{ }_{14} \mathrm{O}_{49}\right]^{5-}$. New J. Chem. 40, 8488-8492 (2016).

204 Dumas, E., Debiemme-Chouvy, C. \& Sevov, S. C. A reduced polyoxomolybdenum borophosphate anion related to the Wells-Dawson clusters. J. Am. Chem. Soc. 124, 908-909 (2002).

205 Sassoye, C., Norton, K. \& Sevov, S. C. $\left[\mathrm{Mo}_{5}{ }^{\mathrm{V}} \mathrm{Mo}_{7}{ }^{\mathrm{VI}} \mathrm{O}_{30}\left(\mathrm{BPO}_{4}\right)_{2}\left(\mathrm{O}_{3} \mathrm{P}-\mathrm{Ph}\right)_{6}\right]^{5-}:$ A phenyl-substituted molybdenum(V/VI) borophosphate polyoxometalate. Inorg. Chem. 42, 1652-1655 (2003).

206 Khan, M. I., Tabussum, S., Doedens, R. J., Golub, V. O. \& O’Connor, C. J. Functionalized metal oxide clusters: synthesis, characterization, crystal structures, and magnetic properties of a novel series of fully reduced heteropolyoxovanadium cationic clusters decorated with organic ligands - $\left[\mathrm{MV}_{6}^{\mathrm{IV}} \mathrm{O}_{6}\left\{\left(\mathrm{OCH}_{2} \mathrm{CH}_{2}\right)_{2} \mathrm{~N}\left(\mathrm{CH}_{2} \mathrm{CH}_{2} \mathrm{OH}\right)\right\}_{6}\right] X(\mathrm{M}=\mathrm{Li}, \mathrm{X}=\mathrm{Cl} \cdot \mathrm{LiCl} ; \mathrm{M}=\mathrm{Na}$, $\mathrm{X}=\mathrm{Cl} \cdot \mathrm{H}_{2} \mathrm{O} ; \mathrm{M}=\mathrm{Mg}, \mathrm{X}=2 \mathrm{Br} \cdot \mathrm{H}_{2} \mathrm{O} ; \mathrm{M}=\mathrm{Mn}, \mathrm{Fe}, \mathrm{X}=2 \mathrm{Cl} ; \mathrm{M}=\mathrm{Co}, \mathrm{Ni}, \mathrm{X}=2 \mathrm{Cl} \cdot \mathrm{H}_{2} \mathrm{O}$ )Inorg. Chem., 43, 5850-5859 (2004).

207 Khan, M. I. et al. Organo-functionalized metal-oxide clusters: synthesis and characterization of the reduced cationic 
1117

1118

1119

1120

1121

1122

1123

1124

1125

1126

1127

1128

1129

1130

1131

1132

1133

1134

1135

1136

1137

1138

1139

1140

1141

1142

1143

1144

1145

1146

1147

1148

1149

1150

1151

1152

1153

species $\left[\mathrm{NaVV}_{6}^{\mathrm{IV}} \mathrm{O}_{6}\left\{\left(\mathrm{OCH}_{2} \mathrm{CH}_{2}\right)_{2} \mathrm{NH}\right\}_{6}\right]^{+}$. Dalton Trans. 43, 16509-16514 (2014).

208 Khan, M. I., Tabussum, S., \& Doedens, R. J. A novel cationic heteropolyoxovanadium(IV) cluster functionalized with organic ligands: synthesis and characterization of the fully reduced species $\left[\mathrm{Mn}^{\mathrm{II}} \mathrm{V}_{6}^{\mathrm{IV}} \mathrm{O}_{6}\left\{\left(\mathrm{OCH}_{2} \mathrm{CH}_{2}\right)_{2} \mathrm{~N}\left(\mathrm{CH}_{2} \mathrm{CH}_{2} \mathrm{OH}\right)\right\}_{6}\right] \mathrm{Cl}_{2}$. Chem. Commun., 532-533 (2004).

209 Zhang, Y.-T. et al. Synthesis, structures, and magnetic properties of metal-organic polyhedra based on unprecedented $\left\{\mathrm{V}_{7}\right\}$ isopolyoxometalate clusters. Dalt. Trans. 45, 14898-14901 (2016).

210 Zhang, Y.-T. et al. Anderson-like alkoxo-polyoxovanadate clusters serving as unprecedented second building units to construct metal-organic polyhedra. Chem. Commun. 47, 3909-3913 (2016).

211 Mak, W. \& Huangb, K. A Hexanuclear oxovanadium(IV) anionic aggregate containing $\mu_{2}$ - and $\mu_{6}$-carbonato groups: synthesis and structural characterization of $\left(\mathrm{NH}_{4}\right)_{5}\left[(\mathrm{VO})_{6}(\mathrm{CO})_{4}(\mathrm{OH})_{9}\right] \cdot 10 \mathrm{H}_{2} \mathrm{O}$. J. Chem. Soc., Chem. Commun., 1597-1598 (1986).

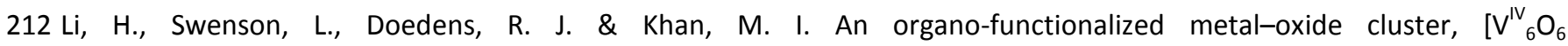
$\left.\left\{\left(\mathrm{OCH}_{2} \mathrm{CH}_{2}\right)_{2} \mathrm{~N}\left(\mathrm{CH}_{2} \mathrm{CH}_{2} \mathrm{OH}\right)\right\}_{6}\right]$, with Anderson-like structure. Dalt. Trans. 45, 16511-16518 (2016).

213 Haushalter, R. C. \& Lai, F. W. Synthesis of a new one-dimensional sodium molybdenum phosphate polymer: structure of $\left[\left(\mathrm{H}_{3} \mathrm{O}\right)_{2} \mathrm{NaMo}_{6} \mathrm{P}_{4} \mathrm{O}_{24}(\mathrm{OH})_{7}\right]^{2-}$. Inorg. Chem. 28, 2904-2905 (1989).

214 Manos, M. J., Keramidas, A. D., Woollins, J. D., Slawin, A. M. Z. \& Kabanos, T. A. The first polyoxomolybdenum carbonate compound: Synthesis and crystal structure of $\left(\mathrm{NH}_{4}\right)_{5}\left[\left(\mathrm{Mo}_{2}{ }^{\mathrm{V}} \mathrm{O}_{4}\right)_{3}\left(\mu_{6}-\mathrm{CO}_{3}\right)\left(\mu-\mathrm{CO}_{3}\right)_{3}(\mu-\mathrm{OH})_{3}\right] \cdot 0.5 \mathrm{CH}_{3} \mathrm{OH}$. J. Chem. Soc. Trans. 3, 3419-3420 (2001). Haushalter, R. C. \& Lai, F. W. $\left[\mathrm{Et}_{4} \mathrm{~N}\right]_{6}\left[\mathrm{Na}_{14} \mathrm{Mo}_{24} \mathrm{P}_{17} \mathrm{O}_{97}(\mathrm{OH})_{31}\right] \cdot \times \mathrm{H}_{2} \mathrm{O}$ : a hollow cluster filled with $12 \mathrm{Na}^{+}$ ions and a $\mathrm{H}_{3} \mathrm{PO}_{4}$ molecule. Angew. Chem. Int. Ed. 28, 743-746 (1989).

215 Mundit, L. A. \& Haushalter, R. C. Hydrothermal synthesis of a layered zinc molybdenum phosphate with octahedral and tetrahedral zinc : structure of $(\mathrm{TMA})_{2}\left(\mathrm{H}_{3} \mathrm{O}\right)_{2}\left[\mathrm{Zn}_{3} \mathrm{Mo}_{12} \mathrm{O}_{30}\left(\mathrm{HPO}_{4}\right)_{2}\left(\mathrm{H}_{2} \mathrm{PO}_{4}\right)_{6}\right] \cdot 11.5 \mathrm{H}_{2} \mathrm{O}$, , Inorg. Chem. 31, 3050-3053 (1992).

216 Mundit, L. A. \& Haushalter, R. C. Hydrothermal synthesis, structure, and sorption properties of the new microporous ferric molybdenum phosphates $\left[\left(\mathrm{CH}_{3}\right)_{4} \mathrm{~N}\right]_{2}\left(\mathrm{NH}_{4}\right)_{2}\left[\mathrm{Fe}_{2} \mathrm{Mo}_{12} \mathrm{O}_{30}\left(\mathrm{H}_{2} \mathrm{PO}_{4}\right)_{6}\left(\mathrm{HPO}_{4}\right)_{2}\right] \cdot \mathrm{nH}_{2} \mathrm{O}$ and $\left[\left(\mathrm{CH}_{3}\right)_{4} \mathrm{~N}\right]_{2} \mathrm{Na}_{4}\left[\mathrm{Fe}_{3} \mathrm{Mo}_{12} \mathrm{O}_{30}\left(\mathrm{H}_{\mathbf{x}} \mathrm{PO}_{4}\right)_{8}\right] \cdot \mathrm{nH}_{2} \mathrm{O}$. Inorg. Chem. 32, 1579-1586 (1993).

217 Cao, G., Haushalter, R. C. \& Strohmaier, K. G. A novel polyoxo molybdenum(V) organophosphonate anion having a sandwich structure: synthesis and crystal structure of $\left[\mathrm{N}\left(\mathrm{C}_{2} \mathrm{H}_{5}\right)_{4}\right]_{2} \mathrm{Na}_{3}\left(\mathrm{H}_{3} \mathrm{O}\right)_{4}\left\{\mathrm{Na}_{2}\left[\mathrm{Mo}_{6} \mathrm{O}_{15}\left(\mathrm{O}_{3} \mathrm{PC}_{6} \mathrm{H}_{5}\right)\left(\mathrm{HO}_{3} \mathrm{PC}_{6} \mathrm{H}_{5}\right)_{3}\right]_{2}\right\} \sim \mathrm{H}_{2} \mathrm{O}$. Inorg. Chem. 32, 127-128 (1993).

218 K. M., Khan, M. I., Chen, Q. \& Zubieta, J. Oxomolybdenum (V) polyanion clusters. Hydrothermal syntheses and structures of $\left.\left(\mathrm{NH}_{4}\right)_{5} \mathrm{Na}_{4}\left\{\mathrm{Na}\left[\mathrm{Mo}_{6} \mathrm{O}_{12}(\mathrm{OH})_{3}\left(\mathrm{O}_{3} \mathrm{PC}_{6} \mathrm{H}_{5}\right)_{4}\right)\right]_{2}\right\} \cdot 6 \mathrm{H}_{2} \mathrm{O}$ and $\left(\mathrm{C}_{6} \mathrm{H}_{5} \mathrm{CH}_{2} \mathrm{NMe}_{3}\right)_{4} \mathrm{~K}_{4}\left\{\mathrm{~K}_{2}\left[\mathrm{Mo}_{6} \mathrm{O}_{12}(\mathrm{OH})_{3}\left(\mathrm{O}_{3} \mathrm{PC}_{6} \mathrm{H}_{5}\right)_{4}\right]_{2}\right\} \cdot 10 \mathrm{H}_{2} \mathrm{O}$ and their relationship to the binuclear $\left(\mathrm{Et}_{4} \mathrm{~N}\right)\left[\mathrm{Mo}_{2} \mathrm{O}_{4} \mathrm{Cl}_{3}\left(\mathrm{H}_{2} \mathrm{O}\right)_{3}\right] \cdot 5 \mathrm{H}_{2} \mathrm{O}$. Inorg. Chim. Acta 235, 135-145 (1995).

219 Manos, M. J., Keramidas, A. D., Woollins, J. D., Slawin, A. M. Z. \& Kabanos, T. A. The first polyoxomolybdenum carbonate compound: Synthesis and crystal structure of $\left(\mathrm{NH}_{4}\right)_{5}\left[\left(\mathrm{Mo}_{2}{ }^{\mathrm{V}} \mathrm{O}_{4}\right)_{3}\left(\mu_{6}-\mathrm{CO}_{3}\right)\left(\mu-\mathrm{CO}_{3}\right)_{3}(\mu-\mathrm{OH})_{3}\right] \cdot 0.5 \mathrm{CH}_{3} \mathrm{OH}$. J. Chem. Soc. Trans. 3, 3419-3420 (2001)..

220 Dolbecq, A., Cadot, E. \& Sécheresse, F. $\left[\mathrm{Mo}_{9} \mathrm{~S}_{8} \mathrm{O}_{12}(\mathrm{OH})_{8}\left(\mathrm{H}_{2} \mathrm{O}\right)_{2}\right]^{2-}$ : a novel polyoxothiomolybdate with a Mo octahedron encapsulated in a reduced Mov cyclic octanuclear core. Chem. Commun., 2293-2294 (1998).

221 Cadot, E., Dolbecq, A., Salignac, B. \& Sécheresse, F. Self-Condensation of $\left[\mathrm{Mo}_{2}{ }_{2} \mathrm{O}_{2} \mathrm{~S}_{2}\right]^{2+}$ with phosphate or arsenate ions by acid-base processes in aqueous solution: syntheses, crystal structures, and reactivity of $\left[\left(\mathrm{HXO}_{4}\right)_{4} \mathrm{Mo}_{6} \mathrm{~S}_{6} \mathrm{O}_{6}(\mathrm{OH})_{3}\right]^{5-}, \mathrm{X}=\mathrm{P}$, 
As. Chem. Eur. J., 5, 2396-2403 (1999).

222 Streb, C., Long, D.-L. \& Cronin, L. Engineering porosity in a chiral heteropolyoxometalate-based framework: the supramolecular effect of benzenetricarboxylic acid. Chem. Commun. 471-473 (2007).

$223 \mathrm{Xu}$, L. et al. A manganese molybdenum phosphate with a tunnel : hydrothermalsynthesis, structure and catalytic properties of

$\left(\mathrm{NH}_{3} \mathrm{CH}_{2} \mathrm{CH}_{2} \mathrm{NH}_{3}\right)_{10}\left(\mathrm{H}_{3} \mathrm{O}\right)_{3}\left(\mathrm{H}_{5} \mathrm{O}_{2}\right) \mathrm{Na}_{2}\left[\mathrm{MnMo}_{12} \mathrm{O}_{24}(\mathrm{OH})_{6}\left(\mathrm{PO}_{4}\right)_{4}\left(\mathrm{PO}_{3} \mathrm{OH}\right)_{4}\right]\left[\mathrm{MnMo}_{12} \mathrm{O}_{24}(\mathrm{OH})_{6}\left(\mathrm{PO}_{4}\right)_{6}\left(\mathrm{PO}_{3} \mathrm{OH}\right)_{2}\right] \cdot 9 \mathrm{H}_{2} \mathrm{O} . \quad$ New J. Chem. 23, 1041-1044 (1999).

224 Zhang, H. et al. The highest connected pure inorganic 3D framework assembled by $\left\{\mathrm{P}_{4} \mathrm{Mo}_{6}\right\}$ cluster and alkali metal potassium. RSCAdv. 5, 3552-3559 (2015).

225 Chang, W.-J., Jiang, Y.-C., Wang, S.-L. \& Lii, K.-H. Hydrothermal synthesis of a three-dimensional organic-inorganic hybrid network formed by poly(oxomolybdophosphate) anions and nickel coordination cations. Inorg. Chem. 45, 6586-6588 (2006).

226 Wang, W., Han, Z., Wang, X., Zhao, C. \& Yu, H. Polyanionic clusters $\left[M\left(\mathrm{P}_{4} \mathrm{Mo}_{6}\right)_{2}\right](\mathrm{M}=\mathrm{Ni}, \mathrm{Cd})$ as effective molecular catalysts for the electron-transfer reaction of ferricyanide to ferrocyanide. Inorg. Chem. 55, 6435-6442 (2016).

227 Peloux, C. et al. A new family of layered molybdenum (V) cobalto-phosphates built up of $\left[\mathrm{H}_{14}\left(\mathrm{Mo}_{16} \mathrm{O}_{32}\right) \mathrm{Co}_{16}\left(\mathrm{PO}_{4}\right)_{24}\left(\mathrm{H}_{2} \mathrm{O}\right)_{20}\right]^{10-}$ wheels. Angew. Chem. Int. Ed. 40, 2455-2457 (2001).

228 Peloux, C. et al. A new two-dimensional molybdenum(v) nickel phosphate built up of $\left[\mathrm{H}_{18}\left(\mathrm{Mo}_{16} \mathrm{O}_{32}\right) \mathrm{Ni}_{16}\left(\mathrm{PO}_{4}\right)_{26}(\mathrm{OH})_{6}\left(\mathrm{H}_{2} \mathrm{O}\right)_{8}\right]^{10-}$ wheels. Inorg. Chem. 41, 7100- 7104 (2002).

229 Zhang, Y.-N., Zhou, B.-B., Li, Y.-G., Sua, Z.-H \& Zhao, Z.-F. A new molybdenum(V) nickel phosphate based on divacant $\left[\mathrm{H}_{30}\left(\mathrm{Mo}_{16}^{\mathrm{V}} \mathrm{O}_{32}\right) \mathrm{Ni}_{14}\left(\mathrm{PO}_{4}\right)_{26} \mathrm{O}_{2}(\mathrm{OH})_{4}\left(\mathrm{H}_{2} \mathrm{O}\right)_{8}\right]^{12-}$ wheel. Dalton Trans. $9446-9451$ (2009).

230 Blazevic, A. \& Rompel, A. The Anderson-Evans polyoxometalate: From inorganic building blocks via hybrid organicinorganic structures to tomorrows "Bio-POM" Coord. Chem. Rev., 307, 42-64 (2016).

231 Johnson, G. K. \& Schlemper, E. O. Existence and structure of the molecular ion 18-vanadate(IV). J. Am. Chem. Soc. 100, 3645-3646, (1978).

232 Müller, A., Penk, M., Rohlfing, R., Krickemeyer, E. \& Döring, J. Topologically interesting cages for negative ions with extremely high "coordination number": an unusual property of V-O clusters. Angew. Chemie Int. Ed. English 29, 926-927 (1990)

233 Müller, A., Krickemeyer, E., Penk, M., Walberg, H.J. \& B ögge, H. Spherical mixed-valence $\left[\mathrm{V}_{15} \mathrm{O}_{36}\right]^{5-}$, an example from an unusual cluster family. Angew. Chemie Int. Ed. English 26, 1045-1046 (1987).

234 Gatteschi, D., Tsukerblatt, B., Barra, A. L. \& Brunel, L. C. Magnetic properties of isostructural dodecanuclear polyoxovanadates with six and eight vanadium (IV) ions. Inorganic Chemistry 32, 2114-2117 (1993).

235 Kögerler, P., Tsukerblat, B. \& Müller, A. Structure-related frustrated magnetism of nanosized polyoxometalates: aesthetics and properties in harmony. Dalt. Trans. 39, 21-36 (2010).

236 Müller, A. \& Döring, J. A novel heterocluster with $D_{3}$-symmetry containing twenty-one core atoms: $\left[\mathrm{As}^{\prime \prime \prime \prime}{ }_{2} \mathrm{~V}^{\mathrm{IV}}{ }_{15} \mathrm{O}_{42}\left(\mathrm{H}_{2} \mathrm{O}\right)\right]^{5-}$. Angew. Chemie Int. Ed. English 27, 1721 (1988).

237 Antonova, E., Näther, C. \& Bensch, W. Assembly of $\left[\mathrm{V}_{15} \mathrm{Sb}_{6} \mathrm{O}_{42}\left(\mathrm{H}_{2} \mathrm{O}\right)\right]^{6-}$ cluster shells into higher dimensional aggregates via weak $\mathrm{Sb} \cdots \mathrm{N} / \mathrm{Sb} \cdots \mathrm{O}$ intercluster interactions and a new polyoxovanadate with a discrete $\left[\mathrm{V}_{16} \mathrm{Sb}_{4} \mathrm{O}_{42}\left(\mathrm{H}_{2} \mathrm{O}\right)\right]^{8-}$ cluster 
1191

1192

1193

1194

1195

1196

1197

1198

1199

1200

1201

1202

1203

1204

1205

1206

1207

1208

1209

1210

1211

1212

1213

1214

1215

1216

1217

1218

1219

1220

1221

1222

1223

1224

1225

1226

1227

shell. CrystEngComm 14, 6853 (2012).

238 Wutkowski, A., Näther, C., Kögerler, P. \& Bensch, W. Antimonato polyoxovanadate based three-dimensional framework exhibiting ferromagnetic exchange interactions: synthesis, structural characterization, and magnetic investigation of $\left\{\left[\mathrm{Fe}\left(\mathrm{C}_{6} \mathrm{H}_{14} \mathrm{~N}_{2}\right)_{2}\right]_{3}\left[\mathrm{~V}_{15} \mathrm{Sb}_{6} \mathrm{O}_{42}\left(\mathrm{H}_{2} \mathrm{O}\right)\right]\right\} \cdot 8 \mathrm{H}_{2} \mathrm{O}$. Inorg. Chem. 52, 3280-3284 (2013).

$239 \mathrm{Qi}$, Y. et al. Two unprecedented inorganic-organic boxlike and chainlike hybrids based on arsenic-vanadium clusters linked by nickel complexes. J. Solid State Chem. 180, 382-389 (2007).

240 Wang, J., Näther, C., Speldrich, M., Kögerler, P. \& Bensch, W. Chain and layer networks of germanato-polyoxovanadates. CrystEngComm 15, 10238 (2013).

241 Zheng, S.-T., Zhang, J., Li, B. \& Yang, G.-Y. The first solid composed of $\left[\mathrm{As}_{4} \mathrm{~V}_{16} \mathrm{O}_{42}\left(\mathrm{H}_{2} \mathrm{O}\right)\right]$ clusters. Dalton Trans. 42, 5584-7 (2008).

242 Wutkowski, A., Näther, C., Kögerler, P. \& Bensch, W. $\left[\mathrm{V}_{16} \mathrm{Sb}_{4} \mathrm{O}_{42}\left(\mathrm{H}_{2} \mathrm{O}\right)\left\{\mathrm{VO}\left(\mathrm{C}_{6} \mathrm{H}_{14} \mathrm{~N}_{2}\right)_{2}\right\}_{4}\right]$ : a terminal expansion to a polyoxovanadate archetype. Inorg. Chem. 47, 1916-1918 (2008).

243 Kiebach, R., Näther, C. \& Bensch, W. $\left[\mathrm{C}_{6} \mathrm{H}_{17} \mathrm{~N}_{3}\right]_{4}\left[\mathrm{Sb}_{4} \mathrm{~V}_{16} \mathrm{O}_{42}\right] \cdot 2 \mathrm{H}_{2} \mathrm{O}$ and $\left[\mathrm{NH}_{4}\right]_{4}\left[\mathrm{Sb}_{8} \mathrm{~V}_{14} \mathrm{O}_{42}\right] \cdot 2 \mathrm{H}_{2} \mathrm{O}$ - the first isolated $\mathrm{Sb}$ derivates of the $\left[\mathrm{V}_{18} \mathrm{O}_{42}\right]$ family. Solid State Sci. 8, 964-970 (2006).

244 Wang, X. Q., Liu, L. M., Zhang, G. \& Jacobson, A. J. An extended chain structure formed by covalently linking polyoxovanadate cages with tetrahedral six rings. Chem. Commun. 2472-2473 (2001).

245 Tripathi, A. et al. The first framework solid composed of vanadosilicate clusters the first framework solid composed of vanadosilicate clusters. J. Am. Chem. Soc., 125, 10528-10529 (2003).

246 Whitfield, T., Wang, X. \& Jacobson, A. J. Vanadogermanate cluster anions. Inorg. Chem. 42, 3728-3733 (2003).

247 Monakhov, K. Y., Bensch, W. \& Kögerler, P. Semimetal-functionalised polyoxovanadates. Chem. Soc. Rev. 44, 8443-8483 (2015)

248 Khan, M. I., Yohannes, E. \& Doedens, R. J. A novel series of materials composed of arrays of vanadium oxide container molecules, $\quad\left\{\mathrm{V}_{18} \mathrm{O}_{42}(\mathrm{X})\right\} \quad\left(\mathrm{X}=\mathrm{H}_{2} \mathrm{O}, \quad \mathrm{Cl}^{-}, \quad \mathrm{Br}^{-}\right)$: synthesis and characterization $\left[\mathrm{M}_{2}\left(\mathrm{H}_{2} \mathrm{~N}\left(\mathrm{CH}_{2}\right)_{2} \mathrm{NH}_{2}\right)_{5}\right]\left[\left\{\mathrm{M}\left(\mathrm{H}_{2} \mathrm{~N}\left(\mathrm{CH}_{2}\right)_{2} \mathrm{NH}_{2}\right)_{2}\right\}_{2} \mathrm{~V}_{18} \mathrm{O}_{42}(\mathrm{X})\right] \cdot 9 \mathrm{H}_{2} \mathrm{O}(\mathrm{M}=\mathrm{Zn}, \mathrm{Cd})$. Inorg. Chem. 42, 3125-3129 (2003).

249 Müller, A. \& Döring, J. Topologisch und elektronisch bemerkenswerte "reduzierte“ cluster des typs $\left[\mathrm{V}_{18} \mathrm{O}_{42}(\mathrm{X})\right]^{\mathrm{n-}}\left(\mathrm{X}=\mathrm{SO}_{4}\right.$, $\left.\mathrm{VO}_{4}\right)$ mit $\mathrm{T}_{\mathrm{d}}$-symmetrie und davon abgeleitete cluster $\left[\mathrm{V}_{(18-\mathrm{p})} \mathrm{As}_{2 \mathrm{p}} \mathrm{O}_{42}(\mathrm{X})\right]^{\mathrm{m}-}\left(\mathrm{X}=\mathrm{SO}_{3}, \mathrm{SO}_{4}, \mathrm{H} \mathrm{O}_{2} \mathrm{O}=3,4\right)$. ZAAC 595, 251-274 (1991).

250 Gatteschi, D., Pardi, L., Barra, A. L., Müller, A. \& Döring, J. Layered magnetic structure of a metal cluster ion. Nature 354, 463-465 (1991).

251 Tsukerblat, B., Tarantul, A. \& Müller, A. Low temperature EPR spectra of the mesoscopic cluster $V_{15}$ : The role of antisymmetric exchange. J. Chem. Phys. 125, (2006).

252 Lo, X., Bo, C. \& Poblet, J. M. Electronic Properties of polyoxometalateselectron and proton affinity of mixed -addenda Keggin and Wells - Dawson anions. J. Am. Chem. Soc 12574-12582 (2002).

253 Wu, K. H., Yu, P. Y., Yang, C. C., Wang, G. P. \& Chao, C. M. Preparation and characterization of polyoxometalate-modified poly(vinyl alcohol)/polyethyleneimine hybrids as a chemical and biological self-detoxifying material. Polym. Degrad. Stab. 94, 1411-1418 (2009).

254 Keggin, J. F. Structure of the crystals of 12-phosphotungstic acid. Nature 131, 351 (1933) 
1228

1229

1230

1231

1232

1233

1234

1235

1236

1237

1238

1239

1240

1241

1242

1243

1244

1245

1246

1247

1248

1249

1250

1251

1252

1253

1254

1255

1256

255 Hori, T., Himeno, S. \& Tamada, O. Crystal structure of bis(tetra-n-butylammonium)dodecamolybdosulfate(VI)-(2-), $\left[\mathrm{NBu}_{4}^{\mathrm{n}}\right]_{2}\left[\mathrm{SMo}_{12} \mathrm{O}_{40}\right]$ J. Chem. Soc. Dalton Trans., 2083-2087 (1996).

256 Wang, J., Ma, P., Li, J., \& Niu, J. Hybrid tungstocuprate $\left[\mathrm{Cu}(2,2 \text { '-bpy })_{3}\right] \mathrm{H}_{4}\left[\mathrm{CuW}_{12} \mathrm{O}_{40}\right] \cdot 6 \mathrm{H}_{2} \mathrm{O}$ based on keggin polyoxoanion $\left[\mathrm{CuW}_{12} \mathrm{O}_{40}\right]^{6-}$ with $\mathrm{Cu}$ as heteroatom. Chem. Res. Chinese U., 23, 263-267 (2007).

257 Baker, L. C. W. \& Figgis, J. S. New fundamental type of inorganic complex: hybrid between heteropoly and conventional coordination complexes. Possibilities for geometrical isomerisms in 11-, 12-, 17-, and 18-heteropoly derivatives. J. Am. Chem. Soc. 92, $3794-3797$ (1970).

258 López, X. \& Poblet, J. M. DFT Study on the five isomers of $\mathrm{PW}_{12} \mathrm{O}_{40}{ }^{3-}$ : relative stabilization upon reduction. Inorg. Chem. 43, 6863-6865 (2004).

259 López, X., Carbó, J. J., Bo, C. \& Poblet, J. M. Structure, properties and reactivity of polyoxometalates: a theoretical perspective. Chem. Soc. Rev. 41, 7537-7371 (2012).

260 López, X., Maestre, J. M., Bo, C. and \& Poblet, J. M., Electronic properties of polyoxometalates:A DFT study of $\alpha / \beta$ $\left[\mathrm{XM}_{12} \mathrm{O}_{40}\right]^{\mathrm{n}-}$ relative stability ( $\mathrm{M}=\mathrm{W}$, Mo and $\mathrm{X}$ a main group element). J. Am. Chem. Soc. 123, 9571-9576 (2001).

261 Kehrman, F. Zur Kenntnis der komplexen anorganischen Wren. Z. Anorg. Allgem. Chem., 423- 441(1892),

262 Dawson, B. The Structure of the 9(18)-Heteropoly Anion in Potassium 9(18)-Tungstophosphate, $\mathrm{K}_{6}\left(\mathrm{P}_{2} \mathrm{~W}_{18} \mathrm{O}_{62}\right) \cdot 14 \mathrm{H}_{2} \mathrm{O}$. Acta Crystallogr. 6, 113-126 (1953).

263 Ichida, B. Y. H. \& Sasaki, Y. The structure of hexaguanidinium octadecamolybdodiarsenate enneahydrate. Acta Cryst. C39, 529-533 (1983).

264 Ozawa, Y. \& Sasaki, Y. Synthesis and crystal structure of $\left[\left(\mathrm{CH}_{3}\right)_{4} \mathrm{~N}\right]_{6}\left[\mathrm{H}_{3} \mathrm{BiW}_{18} \mathrm{O}_{60}\right]$. Chem. Lett. 16, 923-926 (1987).

265 Jeannin, Y. \& Martin-Frère, J. X-ray study of $\left(\mathrm{NH}_{4}\right)_{7}\left[\mathrm{H}_{2} \mathrm{AsW}_{18} \mathrm{O}_{60}\right] \cdot 16 \mathrm{H}_{2} \mathrm{O}$ : first example of a heteropolyanion containing protons and arsenic(III). Inorg. Chem. 18, 3010-3014 (1979).

266 Pope, M. T. \& Papaconstantinou, E. Heteropoly blues. II. Reduction of 2:18-tungstates. Inorg. Chem. 6, 1147-1152 (1967).

267 Papaconstantinou, E. \& Pope, M. T. Heteropoly blues. V. Electronic spectra of one- to six-electron blues of 18metallodiphosphate anions. Inorg. Chem. 9, 667-669 (1970).

268 Papaconstantinou, E. \& Pope, M. T. Heteropoly blues. III. Preparation and stabilities of reduced 18-molybdodiphosphates. Inorg. Chem. 6, 1152-1155 (1967)

269 Wang, Y., Li, F., Xu, L., Jiang, N. \& Liu, X. Multidimensional crystal frameworks based on heteropoly blue building block of $\left[\mathrm{SiW}_{10} \mathrm{Mo}(\mathrm{V})_{2} \mathrm{O}_{40}\right]^{6-}$ : synthesis, structures and magnetic properties. Dalton Trans. 42, 5839-5847 (2013). 